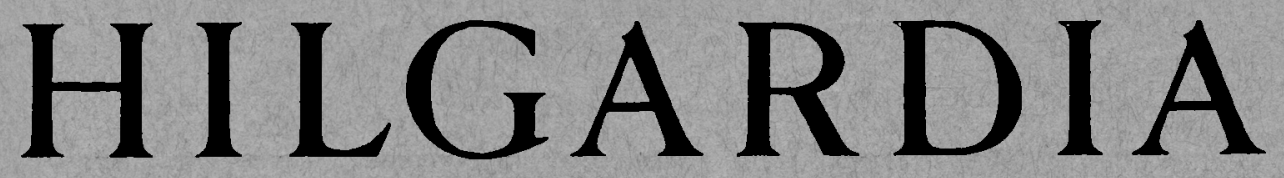

A Journal of Agricultural Science Published by

the California Agricultural Experiment Station

\title{
COMMODITY TOLERANCE STUDIES OF DECIDUOUS FRUITS TO MOIST HEAT AND FUMIGANTS
}

L. L. CLAYPOOL and H. M. VINES 
Studies were made of commodity tolerance of deciduous fruits to various treatments designed as possible conditions for the movement of fruits across quarantine barriers set up for the Oriental and other fruit flies. Of the many chemicals tested the two showing greatest promise were ethylene dibromide and ethylene chlorobromide. The margin of safety between dosages of these two chemicals reported to give complete kill of all stages of certain fruit flies and dosages that damaged the fruit was much greater than with methyl bromide-a widely used fumigant. Bromine residues remaining in treated fruits were small and these dissipated rapidly; they were thought to be of little concern to public health. Should an insect pest such as the Oriental fruit fly become established in California and create a quarantine problem, the successful use of commodity treatments for interstate movement of deciduous tree fruits seems very promising. 


\title{
$\begin{array}{llllllll}H & \text { I } & \text { L } & G & \text { A } & \text { R } & \text { D I } & \text { A }\end{array}$
}

A Journal of Agricultural Science Published by

the California Agricultural Experiment Station

\section{VoL. 24 \\ MARCH, 1956 \\ No. 12 \\ COMMODITY TOLERANCE STUDIES OF DECIDUOUS FRUITS TO MOIST HEAT AND FUMIGANTS ${ }^{1,2}$}

\author{
L. L. CLAYPOOL ${ }^{3}$ and H. M. VINES
}

\section{INTRODUCTION}

The Oriental fruit fly (Dacus dorsalis, Hendel), introduced into the Territory of Hawaii probably in 1945, had by 1948 and early 1949 attained such a population density that it threatened to wipe out the fruit industry of the Islands, except for the pineapple. Concern was very great in the United States, and especially in California, that this insect might gain entrance here, where its devastations would be many times more serious than in Hawaii. The California State Legislature in 1949 took emergency action to make funds available not only for the study of various factors relating to control of the insect but also for studies of commodity treatments which, properly applied, would allow host products from an infested area to pass through quarantine barriers for marketing in clean areas.

Should the Oriental fruit fly become established in California, quarantine barriers quite certainly would be immediately established on a broad geographical or state-wide basis in an attempt to prevent further spread of the insect. Unless acceptable treatments were ready at hand to allow passage of fruits across quarantine barriers, the losses to shippers of fresh fruit would be tremendous and the consumer would be denied the use of host products from quarantine areas.

\section{HOST FRUITS}

The host range of the Oriental fruit fly is very broad (Armitage, 1951). ${ }^{5}$ On the basis of studies by entomologists the deciduous fruits may be placed in the three host categories.

1. Preferred hosts: apricot, berries, cherry, fig, peach, and plum

2. Less preferred hosts: apple, pear, and persimmon

3. Potential but unlikely host: grape

\footnotetext{
${ }^{1}$ Received for publication October 19, 1954.

${ }^{2}$ This report covers investigations conducted under Project 1422(A).

${ }^{3}$ Professor of Pomology and Pomologist in the Agricultural Experiment Station, Davis.

+ Formerly Junior Specialist in Pomology, Davis.

"See "Literature Cited" for citations referred to in the text by author and date.
} 
The preference for a host is greatly increased as ripening advances. Two important crops-almonds and walnuts-are not considered to be quarantine problems. The Oriental fruit fly is not a seed feeder, and if it did attack these 2 species it would do so as a husk fly, and would be separated from the commercial nut at harvest time.

The urgency of the situation in 1949 made it mandatory to explore as rapidly as possible all treatments that would assure the sterilization of potentially infested fruits insofar as the eggs and larvae of the Oriental fruit fly were concerned. Such treatments, while lethal to the insect, must not seriously damage the host. The necessity for such selectivity imposed very serious limitations upon acceptable treatments and required close coöperative effort between entomologists studying the insecticidal characteristics of various treatments and plant physiologists studying commodity tolerances to such treatments.

The only treatments of known potential promise at the beginning of the investigation were fumigation with methyl bromide, sterilization by moist heat (known as "vapor heat"), and prolonged refrigeration. Methyl bromide, although already used successfully as a fumigant for several years, was known to be physiologically active to certain fruits, unfavorably influencing such factors as rate of ripening, storage life, flavor, and resistance to the attack of decay organisms. Since a quarantine treatment must be more severe than a control treatment, the general use of mythyl bromide as a sterilant was not considered exceptionally promising. Vapor heat had been used successfully in Texas, as a sterilant for grapefruit in the Mexican fruit fly program; prior to that in Florida, in connection with the eradication of the Mediterranean fruit fly; and in limited trials in Hawaii. However, its adaptability for deciduous fruit species was unknown. On the other hand, physiological responses of various fruit species to refrigeration had been relatively well known for many years, and it was therefore not considered essential to make further extensive studies on commodity tolerances to cold storage temperatures.

This report deals with (1) vapor heat studies and (2) fumigation studies. Since the 2 types of studies required somewhat different techniques and were variable in the problems encountered, they are reported in separate sections.

\section{VAPOR HEAT STUDIES}

Two vapor heat treatments were used: the "long" treatment, where the commodity was brought up to an internal temperature of $110^{\circ} \mathrm{F}$ and held there for $83 / 4$ hours; and the "short" treatment, where the center of the fruit was brought momentarily to $120^{\circ} \mathrm{F}$ and allowed to cool. The conditions of the treatments were specified by the Bureau of Entomology and Plant Quarantine, United States Department of Agriculture.

\section{Equipment}

Treatment Chambers. Vapor heat chambers were made by modifying two hospital sterilizers of inside dimensions of $31 / 2 \times 4 \times 8$ feet (figures 1 and 2 ). A door at the end of each chamber was replaced by a specially treated ply- 

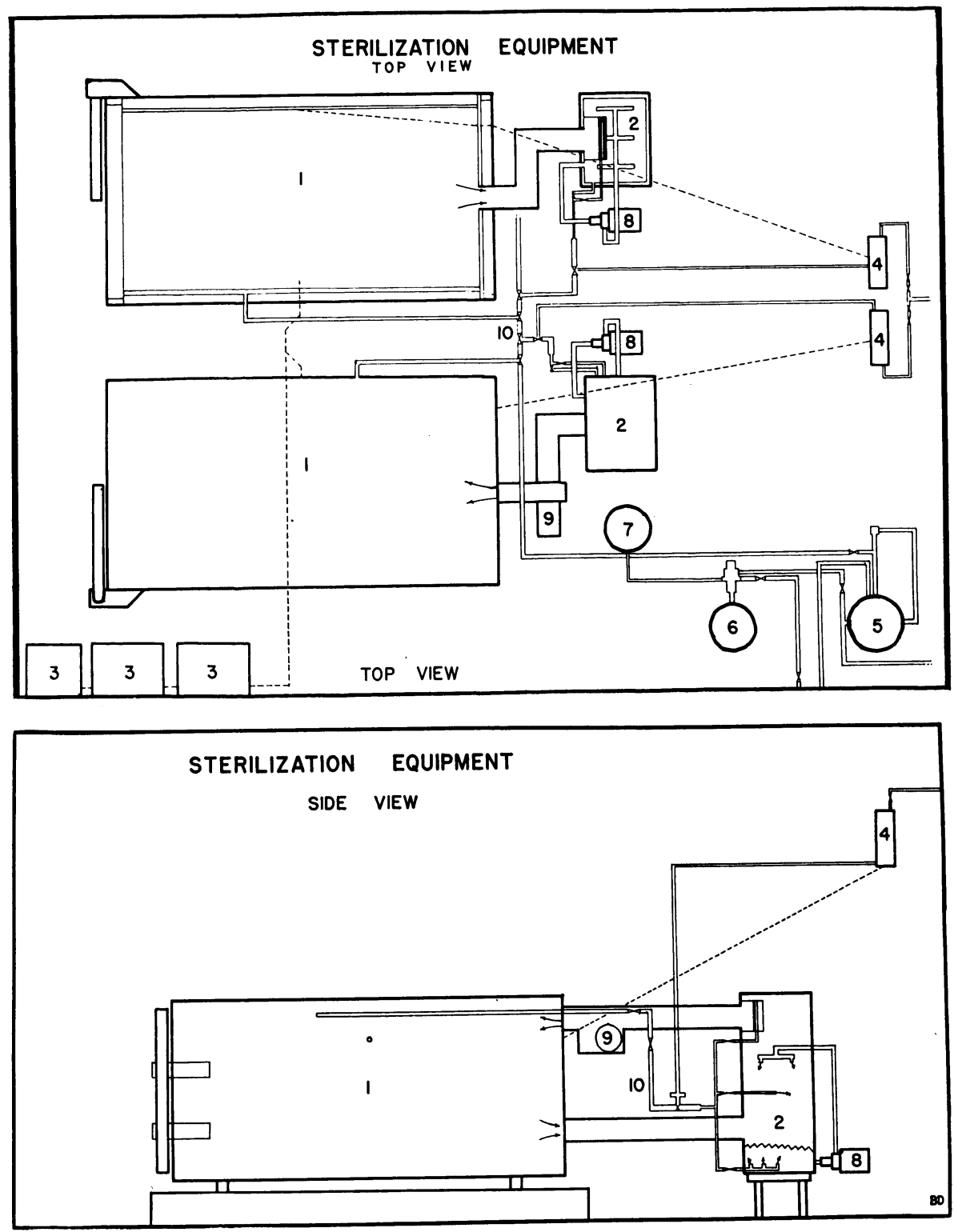

Fig. 1. Diagrammatic drawing of vapor heat chambers: 1) chamber; 2) conditioning chamber ; 3) temperature recorders; 4) recording temperature controllers; 5) steam generator; 6) water softener ; 7) brine tank; 8) water pump ; 9) air circulator; and 10) steam lines. 
wood panel with openings that permitted the entrance of resistance thermometer cables and the circulation of air from an attached conditioning chamber. The desired air temperature was secured by injecting steam into water in a small reservoir and spraying the warm water into the conditioning chamber through which the circulating air from the sterilizer passed. Control was secured by a resistance thermometer placed in the air stream entering the sterilizer. The resistance thermometer activated a pneumatic controller that operated a valve regulating steam injection into the water

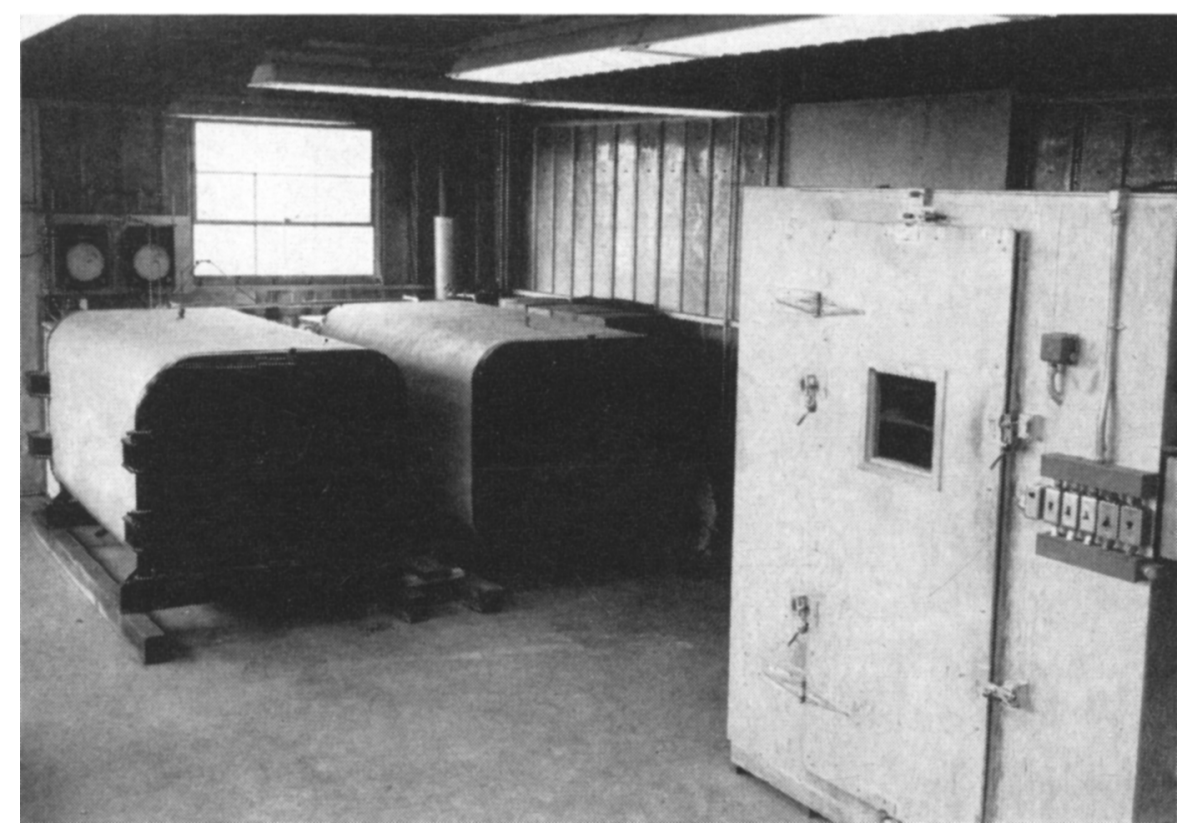

Fig. 2. Photograph of vapor heat and fumigation chambers.

reservoir. Dry steam coils were also built into the conditioning chamber, for use if unsaturated air was desired. The large sterilizer chambers were of double-walled construction, with connections for steam injection into the jacket if a more rapid increase in temperature was desired. Blower fans of sufficient capacity to give about 4 changes of air per minute were used for circulation in the sterilizer and through the spray chambers. In order to reduce heat requirements and temperature variability, the sterilizers (except for the ends) were insulated with about 2 inches of asbestos. Steam was generated with a 4.5 steam-horsepower, dairy-type flash heater operated with natural gas.

This equipment gave excellent temperature control, adhering to the temperature setting within about $\pm 1 / 2^{\circ} \mathrm{F}$ after the initial warm-up period.

Temperature Recorders. Since length of treatment was based on the temperature of the commodity rather than on the air temperature, some accurate record of flesh temperature was essential. This was provided by 
3 six-station, self-balancing recording potentiometers (two Brown "ElectroniK" and one Leeds and Northrup "Speedomax") activated by thermocouples. Two of the instruments were set to record every 30 seconds (completing a cycle every 3 minutes) and the third recorded every 5 seconds (completing a cycle every 30 seconds).

Thermocouples. Thermocouples, considered for this problem to have advantages over other temperature-measuring devices, were used for all of the tests. Iron-constantan wires of 24 gauge were butted together and joined with silver solder.

These thermocouples were used in all early tests and in studies involving heat transfer from the exposed surface to the interior of the fruit, where temperature at known depths from the surface had to be measured. For later experiments, where only flesh temperatures at or near the center of the fruit were desired, thermocouples imbedded in plastic rods were used.

The thermocouples with wires butt-ended together were attached to covered lead wires by soldering the iron-wire segment and after the thermocouple had been threaded through the fruit, by clamping the constantan-wire segment in a brass terminal block. The thermocouples imbedded in plastic were permanently soldered to lead wires. The lead wires first used were 20 gauge, lacquer coated, and wrapped in spun glass, but deviations from the known chamber temperatures were noted after only a few days of use. The trouble was eventually traced to shorts across the lead wires, where moisture had penetrated the protective covering. This was corrected by using lead wires coated with a poly-vinyl plastic.

Commodity Containers. Since the primary problem was to determine how the treatment influenced the physiology of the product, it seemed desirable to use commodity containers that would permit air to move with minimum restrictions. The Los Angeles lug box, 14 × 171/4 × 63/4 inches, was considered to be of suitable size for use in the vapor heat chambers. A modified box was made by joining the wooden end pieces with $1 / 8$-inch strap metal braces at each corner and covering the frame with 20-gauge, 8-mesh hardware cloth. The resulting container, placed with the sides at right angles to the direction of air flow, allowed circulation of air through the commodity with little interference from the container.

\section{Results}

$110^{\circ} \mathrm{F}$ Long Treatment. The original United States Department of Agriculture requirement for the $110^{\circ} \mathrm{F}$ treatment was an 8-hour approach period, during which time the fruit was raised from field temperature to $110^{\circ} \mathrm{F}$, followed by an $83 / 4^{-h o u r ~ h o l d i n g ~ p e r i o d ~ a t ~} 110^{\circ} \mathrm{F}$. This process took at least 17 hours, not counting the time needed for loading and unloading the treatment room. Of course the excessive time meant excessive space requirements, which were considered a serious handicap in the deciduous fruit industry even if the procedure might prove otherwise adaptable. Since it was possible to raise the fruit temperature to $110^{\circ} \mathrm{F}$ in much less time than 8 hours, a shorter approach period was discussed with the commodity treatment group of the Bureau of Plant Industry, United States Department of Agriculture, located in Hawaii. Balock (1950) reported that the mortality of fruit fly 
eggs and larvae was slightly higher when an approach period shorter than 8 hours was used. It was not known whether this was related directly to temperature influences or to the metabolism of the fruit, which in turn may have influenced fruit fly mortality. However, mortality differences did seem to be greater on imbedded than on naked insects. As a result of this information the approach period was greatly reduced, determined primarily by the size of fruit as it influenced heat penetration. With grapes, about 6 hours were saved; with apples and other large fruits, not over 3 hours were saved. Heating would have been slower had these fruits been in commercial boxes

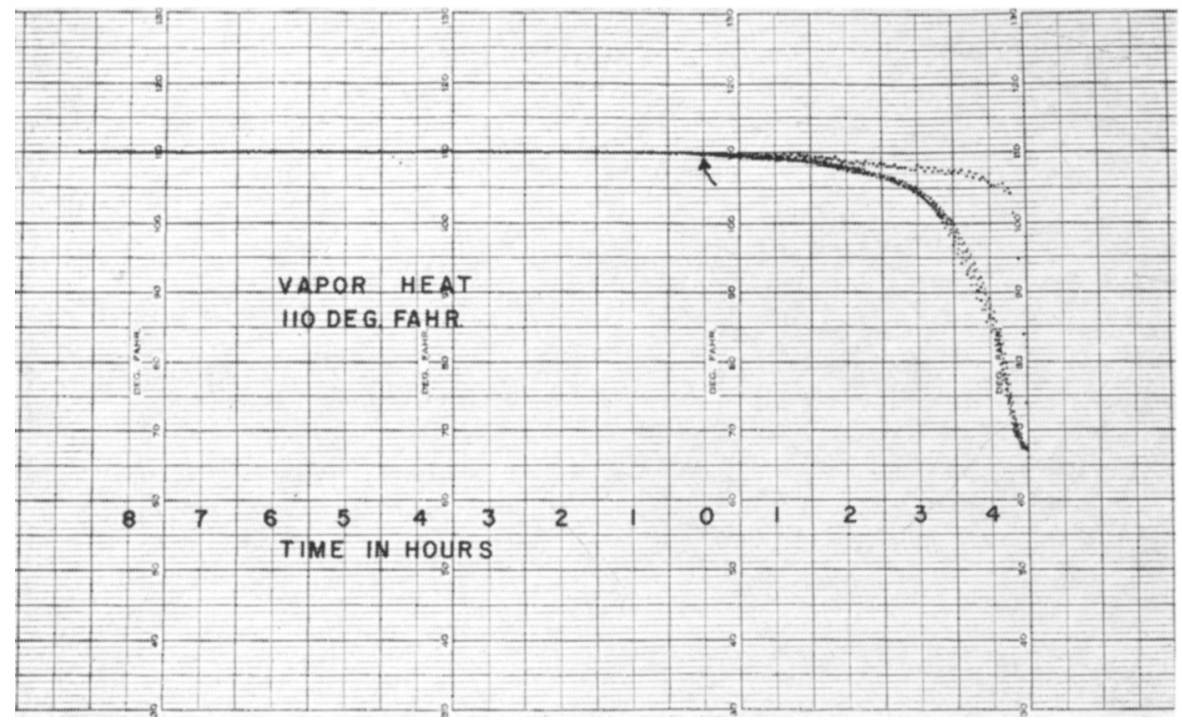

Fig. 3. Typical temperature record of Comice pears in $110^{\circ} \mathrm{F}$ vapor heat treatment.

instead of the specially designed hardware cloth containers. A typical temperature record of fruit during the $110^{\circ} \mathrm{F}$ treatment period is shown in figure 3 .

$120^{\circ} \mathrm{F}$ Short Treatment. The $120^{\circ} \mathrm{F}$ treatment, devised as a substitute for the long $110^{\circ} \mathrm{F}$ treatment, had as its principal feature a great saving in time, since the holding period was eliminated. A typical temperature record of fruits during the $120^{\circ} \mathrm{F}$ treatment is shown in figure 4. Considering time savings only, this treatment would fit into a commercial handling program much better than the $110^{\circ} \mathrm{F}$ treatment.

Fruit Tolerance. Forty-five varieties of fruits representing 12 species were treated during the 1950 and 1951 seasons. Some varieties were used in both years. In 1950 the $110^{\circ} \mathrm{F}$ treatment seemed tolerable to Jonathan apples, Tokay, Red Malaga and White Malaga grapes, Barouni olives, and Winter Nelis pears, but the $120^{\circ} \mathrm{F}$ treatment left only Tokay grapes and Winter Nelis pears undamaged. In 1951 no fruit variety tested appeared tolerant to either vapor heat treatment. Some varieties that appeared tolerant in 1950 
were not used in 1951; there is no certainty as to what their response would have been.

Injury was usually greater with the $120^{\circ} \mathrm{F}$ treatment, but the type of injury was similar with both treatments. The fruit of some grape varieties tended to crack during treatment. Most noticeable were cooked flavor and scalded surface areas. Later, surface bruises became accentuated and in-

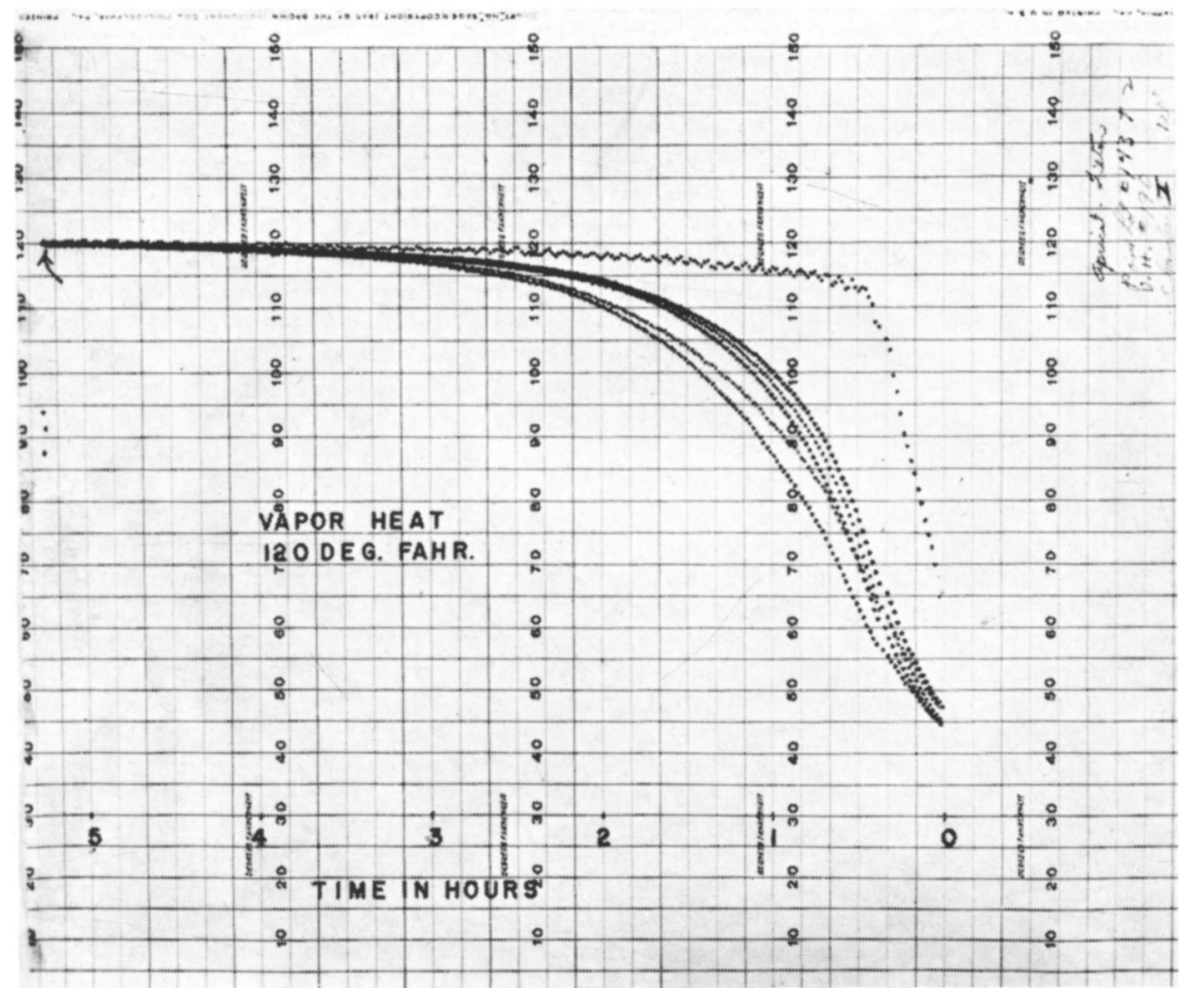

Fig. 4. Typical temperature record of Tilton apricots in $120^{\circ} \mathrm{F}$ vapor heat treatment.

ternal breakdown in the form of browning or tissue sponginess developed. Decay during the marketing period was excessive.

Since injury was so general in fruits of all species there seems very little hope that either of the vapor heat treatments could be adapted to the deciduous fruit industry as a quarantine treatment. Results with deciduous fruits were so unpromising that no attempt was made to study whether a conditioning period at low relative humidity during the approach to $110^{\circ} \mathrm{F}$ would have an ameliorating effect, as reported for certain commodities in Hawaii (Jones, 1940a).

\section{Heat Transfer Studies}

Measurements of the rate of warm-up during the vapor heat tests were made on several fruits. In order to develop this information, thermocouples of 
butt-soldered, 24-gauge wire, as previously described, were threaded through the fruit tissue so that the iron-constantan contact point was at a different, known depth for each thermocouple.

Figure 5 shows the warm-up of Yellow Newtown apples at four depth positions when the air temperature was $110^{\circ} \mathrm{F}$. Heat transfer between warm air and cool fruit is initially a surface phenomenon. However, as the fruit surface is warmed a heat gradient is set up within the fruit tissue, at first covering a thin outside layer and gradually extending into the center of the

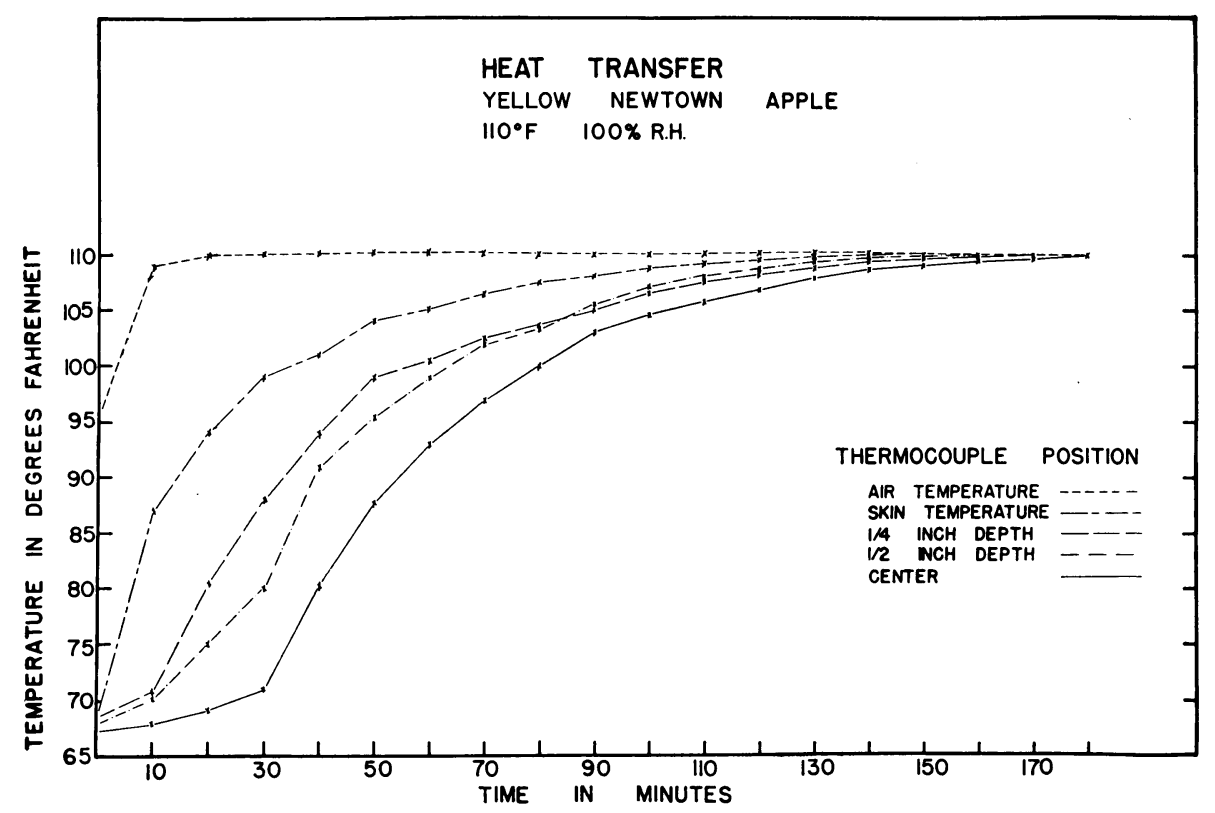

Fig. 5. Thermocouple readings at different depth locations in Yellow Newtown apples during warm-up in $110^{\circ} \mathrm{F}$ vapor heat.

fruit. As the fruit approaches air temperature the heat gradient is so small that final attainment of the last few degrees is slow. No doubt the final heating is assisted by the heat of respiration. The abnormal development of a higher temperature at $1 / 2$-inch depth than at $1 / 4$-inch depth may be explained by the fact that the thermocouples were not placed in the same vertical plane from the outside to the center of the fruit. Then the observed difference might develop if the thermocouple at the $1 / 2$-inch depth was near the top of the fruit and the other was on the under part.

A similar instance is shown in figure 6 , in studies with Bose pears: the temperature at a depth of $1 \frac{1 / 4}{4}$ inches in the top layer of fruit was higher than the temperature at a depth of $3 / 4$ inch in the lower layers. This would indicate that air circulation was somewhat restricted by the fruit in the box even where the package itself offered little resistance to air movement. These studies were not continued to cover individual commercial containers or the influence of stacking procedure upon fruit warm-up. However, there seems 
no doubt that under commercial treatment conditions, somewhat longer warm-up periods would be required to bring all fruits to the desired temperature, and that differences in exposure would result in great variations in temperature attainment among individual fruits. Additional information would have been secured if the results with vapor heat had been promising.

Since heat transfer from warm air to fruit is a surface phenomenon, smaller fruits, having larger surface per unit volume, would be expected to attain a given temperature more rapidly than would larger fruits. Figure 7

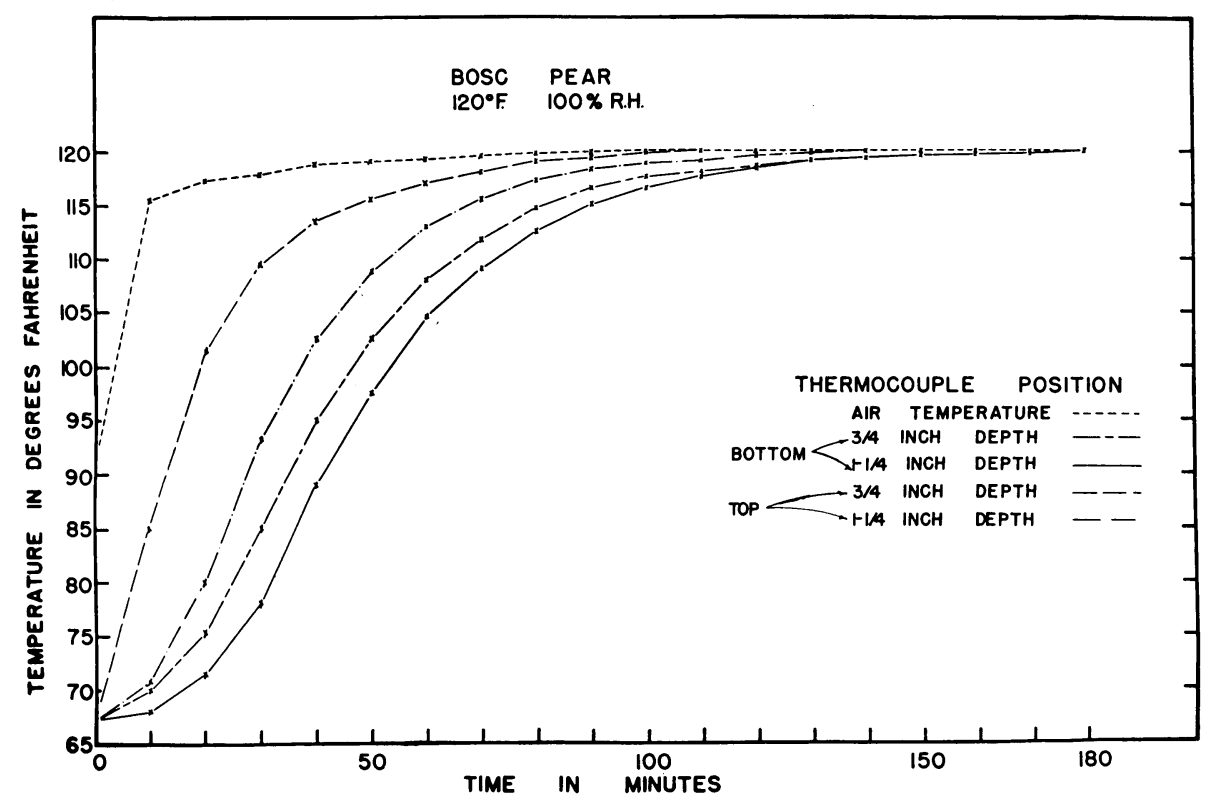

Fig. 6. Thermocouple readings at different locations in Bosc pears during warm-up in $120^{\circ} \mathrm{F}$ vapor heat.

shows the approximate time required to bring different fruits to $110^{\circ} \mathrm{F}$ in a moist $110^{\circ} \mathrm{F}$ atmosphere.

The time required to bring the flesh temperature at the center of the fruit to $110^{\circ} \mathrm{F}$ bears a close relationship to fruit size, although individual fruits were not measured. The slopes of the curves at different times during the treatment period are not subject to close comparison, since each curve in the figure was established by a separate run of the vapor heat chamber. It is conceivable that minor influences could have been exerted by such factors as variability in respiration rate, insulating value of the fruit surface, and the relative amounts of intercellular space within the fruits (including the cluster effect in grapes). No attempt was made in these studies either to demonstrate or to measure the magnitude of such factors.

Figure 8 shows the rate of warm-up of selected fruit species at $120^{\circ} \mathrm{F}$. We have no satisfactory explanation for the fact that a given fruit reaches $120^{\circ}$ $\mathrm{F}$ in slightly less time than it takes to reach $110^{\circ} \mathrm{F}$. It is believed that such 


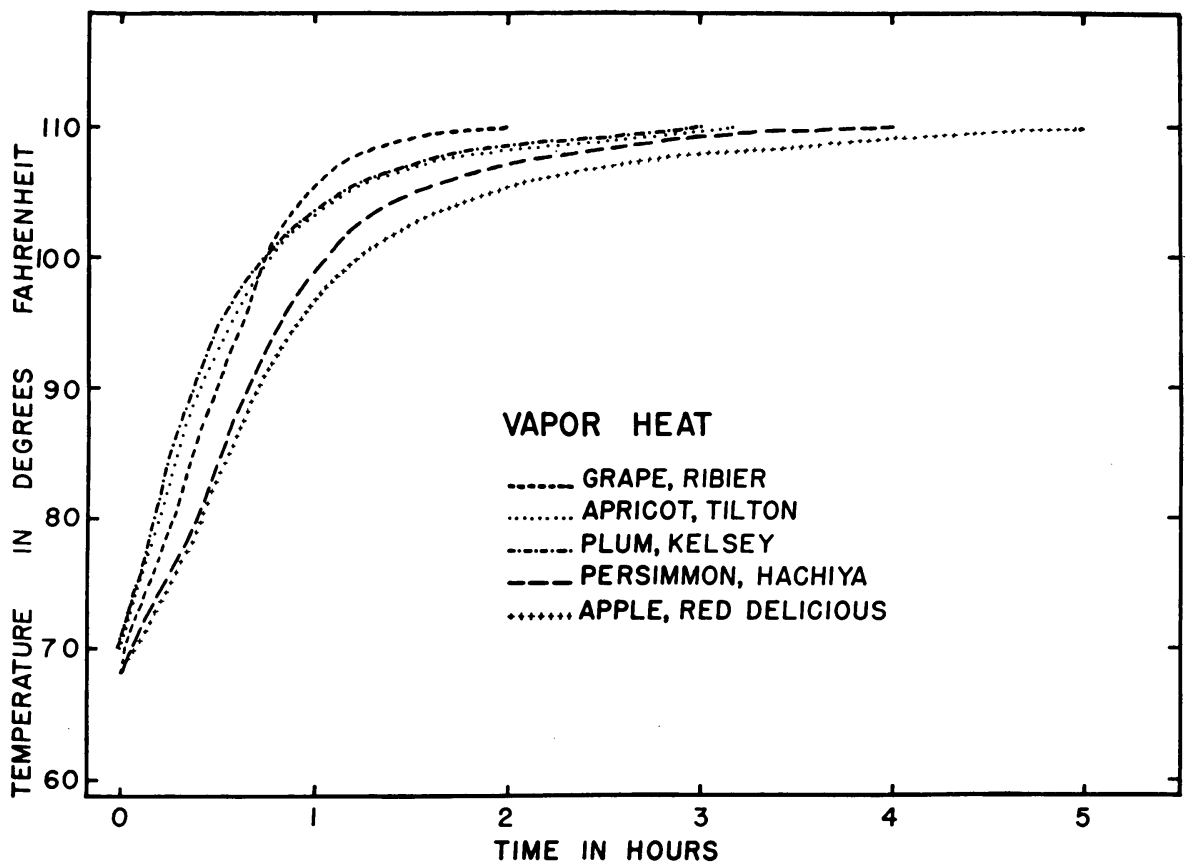

Fig. 7. Warm-up of various fruits in $110^{\circ} \mathrm{F}$ vapor heat.

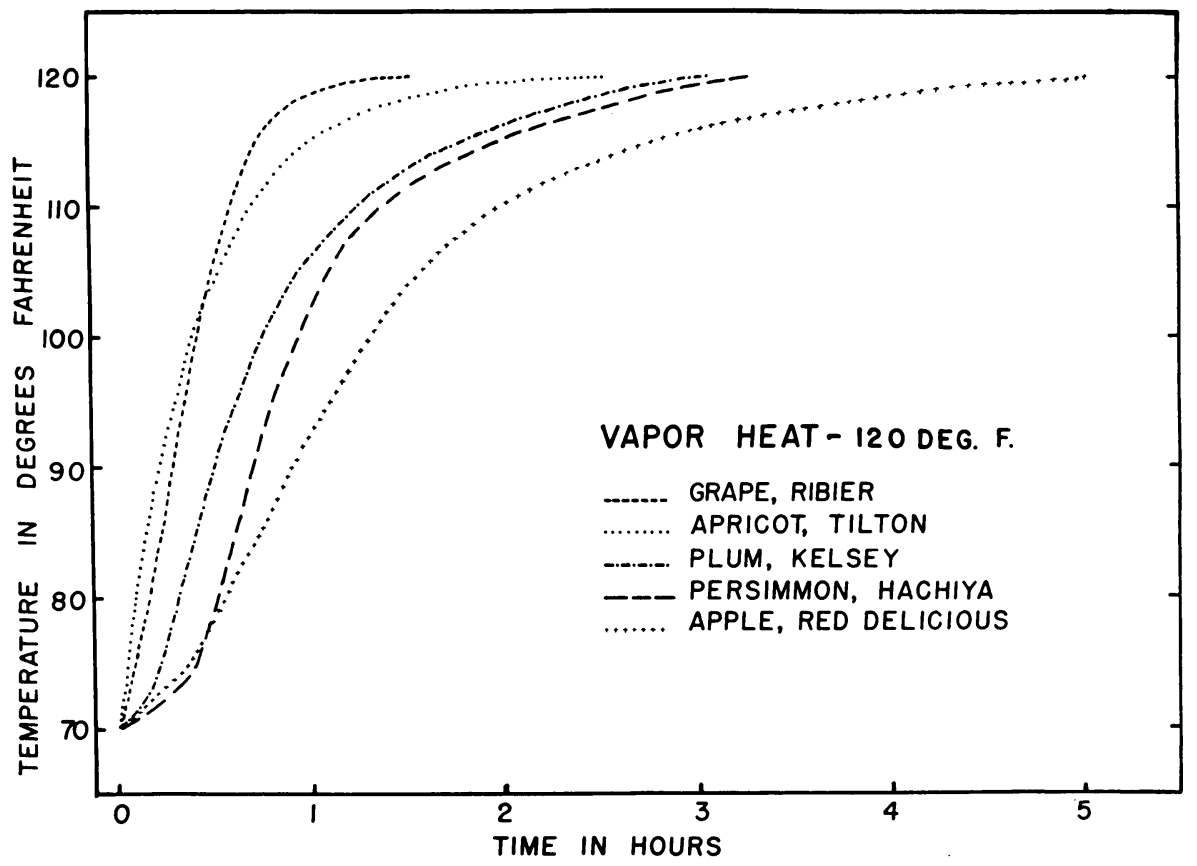

Fig. 8. Warm-up of various fruits in $120^{\circ} \mathrm{F}$ vapor heat. 
differences may be attributable to possible differences in characteristics between the chambers used.

\section{FUMIGATION STUDIES}

In the fall of 1949, methyl bromide was the only promising fumigant known for commodity treatments. In Hawaii in 1950, however, fumigant screening tests made on naked eggs and larvae of the Oriental fruit fly revealed a number of chemicals with adequate insecticidal qualities for consideration as commodity fumigants (Lindgren and Balock, 1950 ; and Balock and Lindgren, 1951). The most promising of these were secured immediately for preliminary trials with fruits. J. W. Balock, in charge of the commodity treatment group in Hawaii, helpfully reported new information on potential commodity fumigants as soon as it was secured. In this way it was possible to develop considerable commodity tolerance information at the same time that more detailed studies were being made on the insecticidal value of the chemicals.

\section{Fumigation Equipment}

Five-gallon Glass Fumigation Chambers. Preliminary commodity tolerance screening trials with all fumigants required so many tests that it was not feasible to conduct these in the experimental fumigation chambers, to be described below. Instead, 5-gallon glass containers were adapted to the work (fig. 9). The jars were filled with 15 to 20 pounds of fruit (approximately three fourths full) and sealed with 2-piece, screw-cap lids. Each of 3 openings in the lid accommodated a piece of copper tubing, soldered in an airtight union. To one of these was attached a cotton gauze wad to intercept liquid fumigants pipetted into the tube, keeping the liquid from direct contact with the fruit and creating a larger surface for evaporation. To one of the other copper tubes was attached a rubber tube extending to the bottom of the jar. This was useful in equalizing pressure when treatment was started and also in accomplishing forced ventilation at the end of the treatment period. The third copper tube, in the center of the lid, housed a propeller shaft. In this way a small propeller in the jar could be operated by an outside motor attached to the shaft by flexible rubber tubing.

The usual procedure was to measure the desired amount of fumigant into a pipette, insert it into the proper tube, and release the liquid onto the cotton gauze. The open tubes were immediately sealed off to prevent loss of fumigant. After about 5 minutes the air in the container was agitated by the small propeller blade for about 1 minute. This process was repeated once, after a few minutes. It is thought that this procedure helped both to volatilize the fumigant and prevent stratification. When methyl bromide was introduced as a gas instead of a liquid, mixing was the only requirement.

Large Fumigation Chambers. Two fumigation chambers, respectively of about 180-cubic-foot and 250-cubic-foot capacities, were used for most of the tests of fumigants that had appeared promising in screening tests in 5-gallon glass containers. The 180 -cubic-foot chamber was a converted walk-in refrigerator box-re-lined with plywood, sealed at the joints with calking compound, and completely painted inside to reduce gas loss to a minimum. The 
equipment within the chamber included a thermostatically controlled heater, a fan for circulating air, an exhaust fan, and wet- and dry-bulb thermometers attached to a recorder mounted outside the box. This chamber was used only for methyl bromide fumigation, metered from an external burette into an evaporating pan in the chamber.

The 250-cubic-foot chamber (figures 2 and 10), used mainly for ethylene dibromide and ethylene chlorobromide, was built especially for fumigation studies. The wooden frame carried about 2 inches of insulation all around. The inner surface was lined with galvanized-iron sheets, soldered at all joints. The door was sealed by means of interlocking channel irons around the door frame and door. The channels were filled with rubber, which gave a tight seal when the door clamps were drawn up. The door had a doubleglass window, permitting observation during the treatment period.

In addition to the customary agitation fan, exhaust fan, thermostatically controlled heater, and wet- and dry-bulb recorder, the chamber was equipped for refrigeration. This was secured by circulating ice water through a heat exchanger controlled thermostatically through the electric pump. In this way it was possible to control temperature in either warm or cool weather within about $\pm 1^{\circ} \mathrm{F}$. A heating mantle with external control was provided for evaporating low-vapor-pressure fumigants. The chamber was also provided with an atomizing nozzle delivering liquid at the rate of about 0.5 gallon per hour at 50 pounds pressure. This nozzle sprayed very fine droplets into a turbulent air stream, which gave effective evaporation of all high-boilingpoint fumigants used. The atomizing nozzle also was used to deliver water into the chamber to build up a high relative humidity.

\section{Procedure in Handling Fruit Lots}

Although most fruits were treated on the day they were harvested, or the next day, it was sometimes necessary to purchase fruit on the wholesale market. Maturity was usually comparable with that of commercial shipments destined for eastern markets. Treated fruit lots were exposed to simulated market conditions: a simulated transit period at $41^{\circ} \mathrm{F}$ usually of 5 to 10 days, followed by a holding period at $68^{\circ} \mathrm{F}$. Those normally shipped to eastern markets by rail freight were usually held at $41^{\circ} \mathrm{F}$ for 10 days, those shipped by express were held at $41^{\circ} \mathrm{F}$ for only 5 days, and those normally inarketed locally were held at $41^{\circ} \mathrm{F}$ for only 2 days. At the end of the simulated transit period the fruits were moved to a $68^{\circ} \mathrm{F}$ constant-temperature room for observation during a simulated marketing period. Observations of condition and taste were made periodically, during both transit and marketing periods.

\section{Chemicals Tested}

During the period of these studies, 16 different chemicals or chemical mixtures (table 1) were tested for commodity tolerance.

At the time 2-bromo-1-chloropropane and chlorasol were selected for test, information on their $\mathrm{LD}_{95}$ (lethal dosage required to kill 95 per cent) was available for eggs but not for larvae. Tests of these fumigants were discontinued as soon as their poor lethal qualities against larvae became known. 


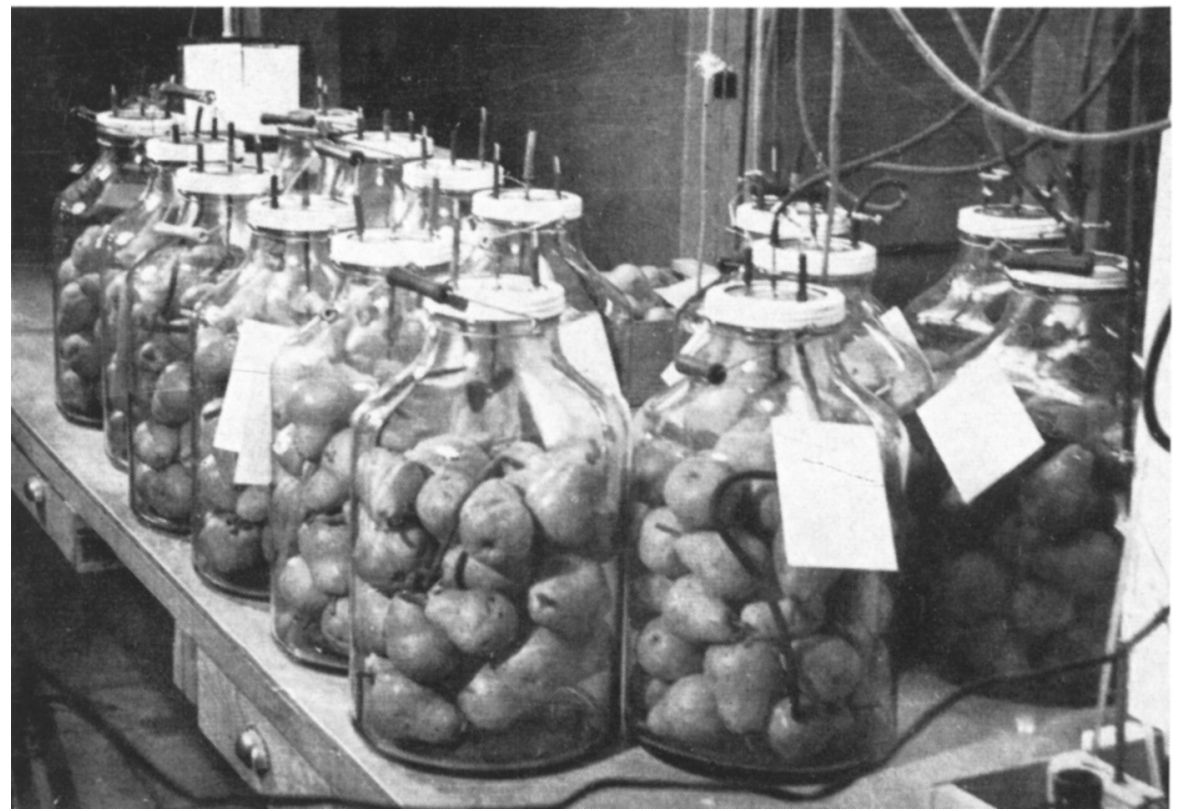

Fig. 9. Five-gallon glass containers used in preliminary fumigation tests.

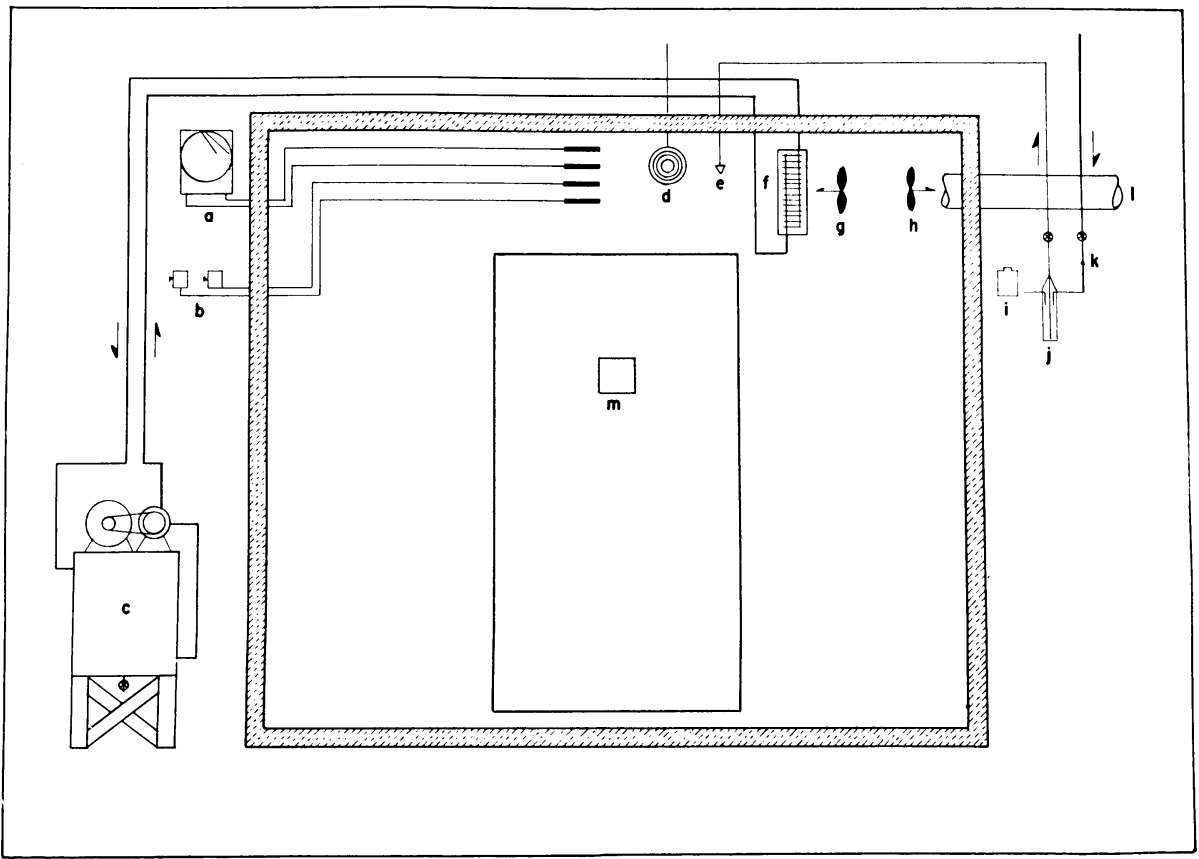

Fig. 10. Diagrammatic drawing of 250-cubic-foot fumigation chamber: a) temperature recorder; b) temperature controls; c) refrigeration (cold-water pump); d) heating coil; e) atomizing nozzle; f) refrigeration heat exchanger; g) eirculation fan ; h) exhaust fan; i) fumigant supply; j) fumigant dispenser; k) compressed air ; l) vent; and m) observation window. 
TABLE 1

PHYSICAL PROPERTIES OF FUMIGANTS TESTED

\begin{tabular}{|c|c|c|c|c|c|c|c|c|}
\hline \multirow{2}{*}{ Chemical } & \multirow{2}{*}{$\begin{array}{c}\text { Molecular } \\
\text { weight }\end{array}$} & \multirow{2}{*}{$\begin{array}{l}\text { Specific } \\
\text { gravity }\end{array}$} & \multirow{2}{*}{$\begin{array}{c}\text { Melting } \\
\text { point }\end{array}$} & \multirow{2}{*}{$\begin{array}{l}\text { Boiling } \\
\text { point }\end{array}$} & \multirow{2}{*}{$\begin{array}{l}\text { Solubility } \\
\text { in } \mathrm{H}_{2} \mathrm{O}\end{array}$} & \multirow{2}{*}{$\begin{array}{c}\text { Vapor } \\
\text { pressure }\end{array}$} & \multicolumn{2}{|c|}{$\mathrm{LD}_{95} *$} \\
\hline & & & & & & & Eggs & Larvae \\
\hline & & & & & & & mg/liter & $m g /$ liter \\
\hline Acrylonitrile................ & 53.06 & $\begin{array}{r}0.806 \\
20^{\circ} / 4\end{array}$ & $-82^{\circ} \mathrm{C}$ & $77.3^{\circ} \mathrm{C}$ & Sol. & $\cdots$ & 1.6 & 1.6 \\
\hline $\begin{array}{l}\text { Benzyl bromide } \ldots \ldots \ldots \ldots \ldots \\
\quad \text { (alpha-bromotoluene) }\end{array}$ & 171.04 & $\begin{array}{r}1.443 \\
17^{\circ}\end{array}$ & -4 & $198-9$ & Insol. & $\cdots$ & 13.0 & 10.5 \\
\hline 2-Bromo-1-chloropropane. . & 157.45 & $\begin{array}{c}1.537 \\
20 \% / 4\end{array}$ & $\cdots$ & 117 & $\cdots$ & $\cdots$ & 26.0 & 195 \\
\hline Chloroacetonitrile......... & 75.5 & $\begin{array}{r}1.193 \\
20^{\circ}\end{array}$ & $\ldots$ & 124 & $\ldots$ & $\ldots$ & 1.5 & $\begin{array}{r}1 \text { than } \\
1.3\end{array}$ \\
\hline $\begin{array}{l}\text { Shell OS } 840 \ldots \ldots \ldots \ldots \ldots \ldots \\
55 \text { per cent w. 1-chloro-3- } \\
\text { bromopropene }\end{array}$ & 155.44 & 1.43 & $\ldots$ & 130 & $\cdots$ & $\cdots$ & 8.7 & 3.4 \\
\hline 1,2-Dibromobutane .... & 215.94 & $\begin{array}{c}1.820 \\
20 \%\end{array}$ & -65 & 166 & Insol. & $\cdots$ & $9.2^{\circ}$ & 9.8 \\
\hline 1,3-Dichloro-2-butene ... & 125.0 & $\begin{array}{r}1.1585 \\
20 \% / 4\end{array}$ & $\begin{array}{l}\text { below } \\
-75\end{array}$ & $\begin{array}{l}127.9 \\
745 \mathrm{~mm}\end{array}$ & $\cdots$ & $\cdots$ & 5.3 & 2.5 \\
\hline Ethyl chloroacetate.......... & 122.55 & $\begin{array}{c}1.159 \\
20 \% / 4\end{array}$ & -26 & 144 & Insol. & $\cdots$ & 13.5 & 3.6 \\
\hline Ethylene chlorobromide...... & 143.43 & $\begin{array}{r}1.689 \\
19^{\circ}\end{array}$ & -16.6 & 106.7 & $\begin{array}{r}0.69 \\
30^{\circ}\end{array}$ & $20^{\circ} \mathrm{C}$ & $\begin{array}{c}\text { than } \\
2.2\end{array}$ & 2.3 \\
\hline Ethylene dibromide. . & 187.88 & $\begin{array}{c}2.180 \\
20^{\circ} / 4\end{array}$ & 10 & 131.5 & $\begin{array}{r}0.43 \\
30^{\circ}\end{array}$ & $\begin{array}{c}6.16 \\
\mathrm{~mm} \mathrm{Hg} \\
\text { at } 6.54^{\circ} \mathrm{C}\end{array}$ & $\begin{array}{c}\text { less } \\
\text { than } \\
2.9\end{array}$ & $\begin{array}{c}\text { less } \\
\text { than } \\
2.9\end{array}$ \\
\hline Methyl bromide............. & 94.95 & $\begin{array}{r}1.732 \\
0 / 0\end{array}$ & -93 & $\begin{array}{c}4.5 \\
758 \mathrm{~mm}\end{array}$ & 0.09 & $\begin{array}{l}\text { greater } \\
\text { than } \\
760 \mathrm{~mm}\end{array}$ & 24.5 & 18.5 \\
\hline Methyl iodide.. & 141.95 & $\begin{array}{l}2.279 \\
20 \% / 4\end{array}$ & -64 & 42.4 & $\begin{array}{c}1.8 \\
15^{\circ}\end{array}$ & $\begin{array}{c}331.4 \mathrm{~mm} \\
20^{\circ}\end{array}$ & $\begin{array}{c}\text { less } \\
\text { than } \\
2.9\end{array}$ & 4.2 \\
\hline $\begin{array}{l}\text { Propylene bromide } \ldots \ldots \ldots \ldots \\
\quad(1,2 \text {-dibromopropane })\end{array}$ & 201.91 & $\begin{array}{c}1.933 \\
20 \% 4\end{array}$ & -55.5 & 141.6 & $\begin{array}{r}0.25 \\
20^{\circ}\end{array}$ & $\begin{array}{l}100 \mathrm{~mm} \\
78.4^{\circ} \mathrm{C}\end{array}$ & 11.5 & 6.3 \\
\hline $\begin{array}{c}\text { Trimethylene bromide } \ldots \ldots \ldots \\
\text { Formulations }\end{array}$ & 201.91 & $\begin{array}{c}1.987 \\
15 \% / 4\end{array}$ & -34.4 & 167.5 & $\begin{array}{l}0.168 \\
30^{\circ} \mathrm{C}\end{array}$ & $\cdots$ & 5.5 & 18.5 \\
\hline $\begin{array}{l}\text { Chlorasol } \ldots \ldots \ldots \ldots \ldots \ldots \ldots \\
\text { ide, } 25 \text { per cent carbon tetra- } \\
\text { chloride) }\end{array}$ & $\cdots$ & 1.33 & $\cdots$ & $\begin{array}{l}\text { estimate } \\
\text { about } 82\end{array}$ & $\ldots$ & $\ldots$ & 7.3 & $\begin{array}{c}\text { greater } \\
\text { than } \\
140\end{array}$ \\
\hline $\begin{array}{l}\text { Dow Fume W85............. } \\
(85 \text { per cent ethylene dibro- } \\
\text { mide, } 15 \text { per cent petroleum } \\
\text { fraction) }\end{array}$ & $\cdots$ & 1.5 & $\cdots$ & $\ldots$ & ... & $\begin{array}{l}47 \mathrm{~mm} \\
70^{\circ} \mathrm{F}\end{array}$ & $\ldots$ & $\ldots$ \\
\hline
\end{tabular}

* The dosage required to be lethal to 95 per cent of a stage of an insect is known as LD95.

$\mathrm{LD}_{95}$ data are from Bureau of Entomology and Plant Quarantine, Commodity Treatment Laboratory, Honolulu, T.H. 
Preliminary commodity tolerance trials were made in 5-gallon glass containers, usually with a range of concentrations and time exposures. While it is possible that calculated dosage, especially of high-boiling-point chemicals, was not reached in these small containers, there can be little doubt that fruits injured under these conditions would have been injured in tests where vaporization of the chemical was assured.

TABLE 2

CLASSIFICATION OF CHEMICALS AS TO INJURIOUS NATURE AND TYPE OF INJURY

\begin{tabular}{|c|c|c|}
\hline Chemical & Group & Type of injury \\
\hline Acrylonitrile. & I & Severe surface scald, some internal browning, and off-flavor \\
\hline Benzyl bromide. & I & Very objectionable off-flavor and odor retained after treatment \\
\hline 2-Bromo-1-chloropropane.... & I & Off-flavor and physiological breakdown \\
\hline Chloroacetonitrile.......... & I & $\begin{array}{l}\text { Severe surface scald, some internal browning, and off-flavor. Injury } \\
\text { less severe than from acrylonitrile }\end{array}$ \\
\hline 1,2-Dibromobutane. & I & Odor and flavor of treated fruits very offensive (skunk) \\
\hline 1,3-Dichloro-2-butene. & I & Treated fruit developed offensive skunk odor and flavor \\
\hline $\begin{array}{c}\text { Shell OS } 840 \text { (CBP 55) } \ldots \ldots \ldots \\
\text { 1-chloro-3-bromopropene) }\end{array}$ & I & Surface browning and off-flavor \\
\hline Ethyl chloroacetate........ & I & $\begin{array}{l}\text { Most fruits developed serious scald following treatment. Many fruits } \\
\text { developed off-flavors }\end{array}$ \\
\hline Propylene bromide. & II & $\begin{array}{l}\text { Off-flavor that disappeared with time, but resulted in reduced eating } \\
\text { quali ty }\end{array}$ \\
\hline Trimethylene bromide. & II & Off-flavor sufficient to reduce dessert quality \\
\hline Dow Fume W-85... & II & Some injury to flavor, and internal browning \\
\hline Chlorasol......... & II-III & Surface injury on a few fruits at very high dosages \\
\hline Methyl bromide. . & II-III & $\begin{array}{l}\text { Some loss of flavor on most fruits. External and internal injury to some } \\
\text { fruits at 2-pound, 4-hour dosage }\end{array}$ \\
\hline Methyl iodide. & II-III & Surface browning and scald at higher dosages \\
\hline Ethylene chlorobromide... & III & $\begin{array}{l}\text { Incipient off-flavor which disappeared rapidly. Flesh browning at high } \\
\text { dosages }\end{array}$ \\
\hline Ethylene dibromide. & III & $\begin{array}{l}\text { Incipient off-flavor which disappeared rapidly. Flesh browning at high } \\
\text { dosages }\end{array}$ \\
\hline
\end{tabular}

The chemicals tested can be divided roughly into 3 groups, as follows:

I. Those that caused serious damge to appearance or flavor at concentrations considered necessary because of $\mathrm{LD}_{95}$ characteristics.

II. Those that often affected fruit flavor or appearance, but usually mildly.

III. Those that impaired appearance, flavor, or keeping quality only slightly at dosages expected to destroy all insects.

Only those chemicals falling into group III were considered worthy of extensive repeated trials. Table 2 designates the chemicals by group and indicates the predominant type of injury resulting from the treatment.

Of the fumigants tested in a preliminary way only 3 besides methyl bromide appeared of sufficient promise to merit further extensive studies. These were methyl iodide, ethylene chlorobromide, and ethylene dibromide. These 4 chemicals will be discussed individually. 


\section{Group I Fumigants}

Acrylonitrile (Propenenitrile) (Vinyl cyanide). Only Emperor and Tokay grapes and President plums seemed tolerant to the treatments used (table 3). Other varieties of the same species were injured. It is thought that the heavy

TABLE 3

TOLERANCE OF VARIOUS FRUITS TO ACRYLONITRILE FUMIGATION

\begin{tabular}{|c|c|c|c|c|c|c|}
\hline Commodity & $1 / 2 \mathrm{lb}, 2 \mathrm{hrs}$ & $1 / 2 \mathrm{lb}, 4 \mathrm{hrs}$ & $1 \mathrm{lb}, 2 \mathrm{hrs}$ & $1 \mathrm{lb}, 4 \mathrm{hrs}$ & $2 \mathrm{lbs}, 2 \mathrm{hrs}$ & $2 \mathrm{lbs}, 4 \mathrm{hrs}$ \\
\hline \multicolumn{7}{|l|}{ APPLES } \\
\hline Golden Delicious... & $\mathrm{x}$ & 0 & 0 & 0 & & \\
\hline Gravenstein......... & 00 & 0 & 00 & 000 & 0 & 0 \\
\hline Jonathan... & 0 & o & 0 & 0 & $\ldots$ & $\ldots$ \\
\hline Red Delicious. & 0 & 0 & 0 & 0 & $\ldots$ & $\ldots$ \\
\hline \multicolumn{7}{|l|}{ APRICOTS } \\
\hline Royal. & $\ldots$ & $\ldots$ & o & o & o & o \\
\hline \multicolumn{7}{|l|}{ Grapes } \\
\hline Emperor... & $\mathrm{x}$ & $\mathrm{x}$ & $\mathrm{x}$ & $\mathbf{x}$ & $\ldots$ & $\ldots$ \\
\hline Thompson Seedless. & 0 & & & 0 & $\ldots$ & $\ldots$ \\
\hline Tokay............ & $\mathrm{x}$ & $\mathrm{x}$ & $\mathrm{x}$ & $\mathrm{x}$ & $\ldots$. & $\ldots$ \\
\hline \multicolumn{7}{|l|}{ Nectarines } \\
\hline Philp . & & $\ldots$ & 0 & 0 & 0 & 0 \\
\hline Stanwick. & 0 & $\ldots$ & $\ldots$ & 0 & $\ldots$ & $\ldots$ \\
\hline \multicolumn{7}{|l|}{ Peaches } \\
\hline Blood Cling. & 0 & $\ldots$ & ... & 0 & & \\
\hline Fay Elberta. & $\ldots$ & $\ldots$ & 0 & 0 & 0 & 0 \\
\hline Shasta.. & $\ldots$ & $\ldots$ & 0 & 0 & 0 & 0 \\
\hline \multicolumn{7}{|l|}{ Pearg } \\
\hline Bartlett. . & 0 & $\ldots$ & $\mathrm{xx}$ & $\mathrm{x} 00$ & 00 & 00 \\
\hline Bose... & o & o & 0 & 0 & $\ldots$ & $\ldots$ \\
\hline \multicolumn{7}{|l|}{ Persimmons } \\
\hline Hachiya. & 0 & 0 & & & $\ldots$ & $\ldots$ \\
\hline Jumbu $\ldots$. & o & o & o & o & $\ldots$ & $\ldots$ \\
\hline \multicolumn{7}{|l|}{ Plums } \\
\hline Becky Smith. & & & 0 & $\mathbf{o}$ & 0 & 0 \\
\hline Giant......... & 0 & 0 & 0 & 0 & $\ldots$ & $\ldots$ \\
\hline Kelsey ........ & 0 & o & o & o & $\ldots$ & $\ldots$ \\
\hline President... & $\mathbf{x}$ & $\mathrm{x}$ & & $\mathbf{x}$ & . & $\ldots$ \\
\hline Wickson... & $\ldots$ & $\ldots$ & $0 \times 0$ & Xo & o & 00 \\
\hline
\end{tabular}

$\mathbf{X}=$ Tolerant to treatment.

$\mathrm{O}=$ Not tolerant to treatment.

cuticle of the resistant fruits effectively protects them from the fumigant, somewhat as grapes are protected during fumigation with sulfur dioxide gas.

Scald, or surface burning, was the most obvious symptom of injury on most fruit species. It was thought to be due to the relatively high solubility of this fumigant in water, which would tend to concentrate at first in the epidermal layers of the fruit. Off-flavor was recorded in several apple and peach varieties. Internal browning or breakdown developed in some apple and pear varieties, but was not noted in stone fruits. However, ripening of apricots, 
figs, persimmons, and several plum varieties was delayed sufficiently to be considered damaging. The severity of injury of all types was closely related to treatment dosage.

The serious injury to most fruits resulting from fumigation with acrylonitrile makes it seem impractical for commercial use, even with apparently tolerant grape varieties.

Benzyl Bromide ( $a$-Bromotoluene). Only 2 fruit species-strawberries and Black Tartarian cherries-had been treated before it became apparent that this chemical was unsuitable as a fresh-fruit fumigant. The residual off-flavor and obnoxious odor that developed persisted throughout the transit and marketing period, rendering the fruit completely unusable.

2-Bromo-1-chloropropane (Propylene chlorobromide). After fumigation at dosages as low as 4 pounds per 1,000 cubic feet all varieties of grapes developed off-flavor (table 4). The flavor of nectarines, peaches, and persimmons was also seriously damaged. Although off-flavor was the most obvious injury symptom some physiological breakdown also occurred.

Apples, pears, and plums appeared tolerant to calculated dosages as high as 10 pounds per 1,000 cubic feet before damage occurred, but this is equivalent only to $160 \mathrm{mg}$ per liter compared with the $195 \mathrm{mg}$ required for $\mathrm{LD}_{95}$. 2-Bromo-1-chloropropane could not be considered to have a potential as a fresh-fruit fumigant, because of the injury that would result at dosages supposedly lethal to fruit fly larvae.

Chloroacetonitrile (Chloromethyl cyanide). Chloroacetonitrile is a chlorinated cyanide. Screening tests in Hawaii, on naked eggs and larvae of the Oriental fruit fly, had indicated that this chemical was as toxic to insects as any material tested.

Most fruits were severely damaged at dosages as low as $1 / 2$ pound per 1,000 cubic feet for 2 hours (table 5). Of the fruits showing tolerance, grapes were least damaged, with the Tokay variety apparently withstanding dosages up to 1 pound for 4 hours, whereas Emperor and Red Malaga varieties appeared uninjured at dosages of $1 / 2$ pound for 2 hours and $1 / 2$ pound for 4 hours. Bartlett pears, Kadota figs, Stanwick nectarines, and Red Delicious apples appeared uninjured at an exposure of $1 / 2$ pound for 2 hours, but were damaged by higher dosages.

Damage was usually in the form of scald and external browning, although internal browning and core breakdown developed in certain fruits. Off-flavor was also recorded in fruits developing other disorders. Ripening, as measured by softening and chlorophyll disappearance, was delayed. However, unless the delay was accompanied by abnormal ripening or some other disorder the fruit was considered to be tolerant to the treatment. In general, the more tolerant fruits were those with a relatively impervious cuticle, such as grapes and the President plum.

Although a few fruits exhibited some tolerance at a dosage level of $1 / 2$ pound for 2 hours, most fruits showed serious damage at this low dosage. It appears certain that chloroacetonitrile cannot be used with safety as a freshfruit fumigant. 
TABLE 4

TOLERANCE OF VARIOUS FRUITS TO 2-BROMO-1-CHLOROPROPANE FUMIGATION

\begin{tabular}{|c|c|c|c|c|c|c|c|c|}
\hline Commodity & $\begin{array}{l}4 \mathrm{lbs}, \\
2 \mathrm{hrs}\end{array}$ & $\begin{array}{l}4 \mathrm{lbs}, \\
4 \mathrm{hrs}\end{array}$ & $\begin{array}{l}6 \mathrm{lbs}, \\
2 \mathrm{hrs}\end{array}$ & $\begin{array}{l}6 \mathrm{lbs}, \\
4 \mathrm{hrs}\end{array}$ & $\begin{array}{l}8 \mathrm{lbs}, \\
2 \mathrm{hrs}\end{array}$ & $\begin{array}{l}8 \mathrm{lbs}, \\
4 \mathrm{hrs}\end{array}$ & $\begin{array}{l}10 \mathrm{lbs} \\
2 \mathrm{hrs}\end{array}$ & $\begin{array}{c}10 \mathrm{lbs}, \\
4 \mathrm{hrs}\end{array}$ \\
\hline \multicolumn{9}{|l|}{ Apples } \\
\hline Golden Delicious. & $\mathrm{X}^{*}$ & & $\mathrm{XX}$ & $\mathrm{XX}$ & $\mathrm{XX}$ & $\mathrm{XX}$ & $\mathrm{XX}$ & $\mathrm{XX}$ \\
\hline Gravenstein...... & $\mathrm{XXX}$ & $\mathrm{xx}$ & $\mathrm{XX}$ & $\mathrm{XX}$ & $\mathrm{xX}$ & $\mathrm{XXX}$ & $\ldots$ & $\ldots$ \\
\hline Jonathan........... & $\ldots$ & $\ldots$ & $\mathrm{X}$ & $\mathrm{x}$ & $\mathrm{X}$ & $\mathrm{X}$ & $\mathrm{O}$ & $\mathrm{O}$ \\
\hline Red Delicious....... & $\mathrm{X}^{*}$ & $\ldots$ & $\mathrm{X}$ & $\mathrm{X}$ & $\mathrm{X}$ & $\mathrm{X}$ & $\mathrm{O}$ & $\mathrm{O}$ \\
\hline Rome Beauty ........ & $\ldots$ & $\ldots$ & $\mathrm{X}$ & $\mathrm{X}$ & $\mathrm{O}$ & $\mathrm{O}$ & $\ldots$ & $\ldots$ \\
\hline Yellow Newtown ..... & $\mathrm{X}^{*}$ & $\mathrm{X}$ & $\mathrm{x}$ & $\mathrm{X}$ & $\mathrm{x}$ & $\mathrm{O}$ & $\mathrm{O}$ & $\mathrm{O}$ \\
\hline \multicolumn{9}{|l|}{ APRICOTS } \\
\hline 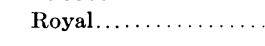 & $\mathrm{X}$ & $\mathrm{x}$ & $\mathrm{x}$ & $\mathrm{x}$ & $\mathrm{x}$ & $\mathbf{x}$ & $\cdots$ & $\ldots$ \\
\hline \multicolumn{9}{|l|}{ FIgS } \\
\hline Kadota.... & $\cdots$ & $\cdots$ & $\mathrm{O}$ & $\mathrm{O}$ & $\mathrm{O}$ & $\mathrm{O}$ & $\mathrm{O}$ & O \\
\hline \multicolumn{9}{|l|}{ Grapes } \\
\hline Emperor..... & $\mathrm{O}^{*} \mathrm{O}$ & $\mathrm{O}$ & O & $\mathrm{O}$ & $\ldots$ & $\ldots$ & $\ldots$ & $\ldots$ \\
\hline Red Malaga........... & $\ldots$ & $\ldots$ & $\mathrm{O}$ & $\mathrm{O}$ & $\mathrm{O}$ & $\mathrm{O}$ & $\mathrm{O}$ & $\mathrm{O}$ \\
\hline Thompson Seedless . . & OO & $\ldots$ & $\mathrm{O}$ & $\mathrm{O}$ & $\mathrm{O}$ & $\mathrm{OO}$ & $\mathrm{O}$ & O \\
\hline Tokay............... & $\ldots$ & $\ldots$ & $\mathrm{O}$ & $\mathrm{O}$ & $\mathrm{O}$ & $\mathrm{O}$ & $\mathrm{O}$ & $\mathrm{O}$ \\
\hline \multicolumn{9}{|l|}{ Nectarines } \\
\hline Philp...... & $\mathrm{O}$ & $\mathrm{O}$ & O & O & $\mathrm{O}$ & $\mathrm{O}$ & $\ldots$ & $\ldots$ \\
\hline Stanwick . . & $\mathrm{X}$ & $\ldots$ & $\ldots$ & $\ldots$ & $\ldots$ & $\mathrm{X}$ & $\ldots$ & $\ldots$ \\
\hline \multicolumn{9}{|l|}{ Peaches } \\
\hline Blood Cling. . & $\ldots$ & $\ldots$ & $\mathrm{X}$ & $\ldots$ & $\ldots$ & $\ldots$ & $\ldots$ & O \\
\hline Fay Elberta.......... & $\mathrm{O}$ & $\mathrm{O}$ & $\mathrm{O}$ & $\mathrm{O}$ & $\mathrm{O}$ & $\mathrm{O}$ & $\ldots$ & $\ldots$ \\
\hline Gaume............. & $\mathrm{x}$ & $\ldots$ & $\ldots$ & ... & $\ldots$ & $\mathrm{O}$ & $\ldots$ & $\ldots$ \\
\hline Kirkman............ & $\ldots$ & $\ldots$ & $\mathrm{O}$ & 0 & $\mathrm{O}$ & $\mathrm{O}$ & $\mathrm{O}$ & $\mathrm{O}$ \\
\hline Shasta............. & $\mathrm{X}$ & $\mathrm{x}$ & $\mathrm{X}$ & $\mathrm{X}$ & $\mathrm{X}$ & $\mathrm{X}$ & $\ldots$ & $\ldots$ \\
\hline \multicolumn{9}{|l|}{ Pears } \\
\hline Bartlett. & $\mathrm{XxXX} * \mathrm{Xx}$ & $\mathrm{x} \times \mathrm{XX}$ & $\mathrm{x} \times \mathrm{XX}$ & $\mathrm{x} \times \mathrm{Xx}$ & $\mathrm{x} \times \mathrm{xx}$ & $\mathrm{XXXX}$ & $\ldots$ & $\ldots$ \\
\hline Bosc.......... & $\mathrm{X}^{*}$ & $\ldots$ & $\mathrm{x}$ & $\mathrm{x}$ & $\mathrm{X}$ & $\mathrm{x}$ & $\mathrm{X}$ & $\mathrm{x}$ \\
\hline Winter Nelis... & $\mathrm{X}^{*}$ & $\ldots$ & $\ldots$ & $\ldots$ & $\ldots$ & $\ldots$ & $\ldots$ & $\ldots$ \\
\hline \multicolumn{9}{|l|}{ Persimmons } \\
\hline Hachiya... & $\mathrm{O}^{*} \mathrm{O}$ & $\mathrm{O}$ & $\mathrm{O}$ & O & $\ldots$ & $\ldots$ & $\ldots$ & $\ldots$ \\
\hline Jumbu ............ & $\mathrm{O}$ & $\mathrm{O}$ & $\ldots$ & $\ldots$ & $\ldots$ & $\cdots$ & $\ldots$ & $\ldots$ \\
\hline \multicolumn{9}{|l|}{ Plums } \\
\hline Becky Smith. & $\mathrm{x}$ & $\mathrm{x}$ & $\mathrm{x}$ & $\mathrm{x}$ & $\mathbf{x}$ & $\mathrm{x}$ & $\ldots$ & $\ldots$ \\
\hline 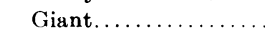 & $\ldots$ & $\ldots$ & $\mathrm{X}$ & $\mathrm{X}$ & $\mathbf{x}$ & $\mathrm{x}$ & $\mathrm{O}$ & $\mathrm{O}$ \\
\hline Kelsey.... & $\mathrm{X}$ & $\mathrm{X}$ & $\mathrm{X}$ & $\mathrm{X}$ & $\mathrm{X}$ & $\mathrm{X}$ & $\ldots$ & $\ldots$ \\
\hline President. & $\ldots$ & .. & $\mathrm{X}$ & $\mathrm{X}$ & $\mathrm{X}$ & $\mathrm{X}$ & $\mathbf{X}$ & $\mathrm{X}$ \\
\hline Wickson... & $\mathrm{x} \times \mathrm{x}$ & $\mathrm{XX}$ & $\mathrm{XX}$ & $\mathrm{XX}$ & $\mathrm{XX}$ & $\mathrm{XXX}$ & $\ldots$ & $\ldots$ \\
\hline
\end{tabular}

* Treated in large fumigation chamber.

$\mathrm{X}=$ Tolerant to treatment.

$\mathrm{O}=$ Not tolerant to treatment.

1,2-Dibromobutane. Although actual dosages of 1,2-dibromobutane may have been lower than calculated dosages, all fruit treated with this chemical had an objectionable "skunk" odor and flavor, evident immediately after treatment and persisting throughout the observation period. The odor was not so bad as that experienced with 1,3-dichloro-2-butene. 
The deleterious effect to all fruit so treated indicates that this chemical has no potential as a fumigant of fresh fruits.

1,3-Dichloro-2-butene. Preliminary trials were conducted in 1950 with Gravenstein apples, Thompson Seedless grapes, Fay Elberta peaches, Bart-

TABLE 5

TOLERANCE OF VARIOUS FRUITS TO CHLOROACETONITRILE FUMIGATION

\begin{tabular}{|c|c|c|c|c|c|c|}
\hline Commodity & $1 / 2 \mathrm{lb}, 2 \mathrm{hrs}$ & $1 / 2 \mathrm{lb}, 4 \mathrm{hrs}$ & $1 \mathrm{lb}, 2 \mathrm{hrs}$ & $1 \mathrm{lb}, 4 \mathrm{hrs}$ & $3 \mathrm{lbs}, 2 \mathrm{hrs}$ & $3 \mathrm{lbs}, 4 \mathrm{hrs}$ \\
\hline \multicolumn{7}{|l|}{ APPLES } \\
\hline Golden Delicious.. & o & $\mathbf{O}$ & $\mathbf{0}$ & $\mathbf{O}$ & $\ldots$ & $\ldots$ \\
\hline Gravenstein .............. & 00 & O & 00 & 000 & o & $\mathbf{0}$ \\
\hline Jonathan..................... & o & O & o & $\mathbf{O}$ & $\ldots$ & $\ldots$. \\
\hline Red Delicious..... & $\mathbf{x}$ & 0 & o & o & $\ldots$ & $\ldots$ \\
\hline \multicolumn{7}{|l|}{ Apricots } \\
\hline Royal.......... & $\ldots$ & $\ldots$ & 0 & 0 & 0 & 0 \\
\hline \multicolumn{7}{|l|}{ Figs } \\
\hline Kadota. & $\mathbf{x}$ & $\ldots$ & $\ldots$ & 0 & $\ldots$ & $\ldots$ \\
\hline \multicolumn{7}{|l|}{ Grapes } \\
\hline Emperor............ & $\mathbf{x}$ & $\mathrm{x}$ & o & 0 & $\ldots$ & $\ldots$ \\
\hline Red Malaga.... & $\mathbf{x}$ & $\mathbf{x}$ & $\mathbf{0}$ & O & $\ldots$ & $\cdots$ \\
\hline Thompson Seedless... & 0 & $\ldots$ & ... & 0 & $\ldots$ & $\cdots$ \\
\hline Tokay.............. & $\mathbf{x}$ & $\mathbf{x}$ & $\mathrm{x}$ & $\mathbf{x}$ & $\ldots$ & $\ldots$ \\
\hline \multicolumn{7}{|l|}{ Nectarines } \\
\hline Philp..... & $\ldots$ & $\ldots$ & o & 0 & 0 & o \\
\hline Stanwick.... & $\mathbf{x}$ & $\cdots$ & $\cdots$ & $\mathrm{o}$ & $\cdots$ & $\cdots$ \\
\hline \multicolumn{7}{|l|}{ Peaches } \\
\hline Blood Cling. & o & $\ldots$ & $\ldots$ & $\mathbf{O}$ & $\ldots$ & $\ldots$ \\
\hline Fay Elberta $\ldots \ldots \ldots \ldots \ldots \ldots$ & $\ldots$ & $\ldots$ & 0 & $\mathbf{0}$ & 0 & 0 \\
\hline \multicolumn{7}{|l|}{ Pearg } \\
\hline Bartlett...... & $\mathrm{x} \times$ & 0 & 00000 & 00000 & 000 & 000 \\
\hline 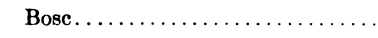 & 0 & o & o & o & $\ldots$ & $\ldots$ \\
\hline \multicolumn{7}{|l|}{ Persimmons } \\
\hline Hachiya... & 0 & 0 & $\cdots$ & $\ldots$ & $\ldots$ & $\ldots$ \\
\hline Jumbu $\ldots \ldots \ldots \ldots \ldots \ldots \ldots$ & 0 & 0 & 0 & 0 & $\cdots$ & $\cdots$ \\
\hline \multicolumn{7}{|l|}{ Plums } \\
\hline Becky Smith.................. & ... & $\ldots$ & o & o & $\ldots$ & $\cdots$ \\
\hline Giant....................... & $\mathbf{0}$ & 0 & o & o & $\ldots$ & $\cdots$ \\
\hline Kelsey ................. & $\mathbf{0}$ & o & $\mathbf{0}$ & 0 & $\cdots$ & $\cdots$ \\
\hline President.... & $\mathbf{x}$ & $\mathbf{x}$ & $\mathbf{o}$ & o & $\ldots$ & $\ldots$ \\
\hline Wickson..................... & $\ldots$ & 000 & 00 & 00 & 00 & 000 \\
\hline
\end{tabular}

$\mathrm{X}=$ Tolerant to treatment.

$0=$ Not tolerant to treatment.

lett pears, and Giant and Kelsey plums, using dosages of 1 pound, 2 and 4 hours and 3 pounds, 2 and 4 hours. This chemical seems to be innocuous in odor, but a very offensive "skunk" odor develops when it contacts organic matter. As a result, all treated fruits not only were unpalatable themselves but the offensive odor was imparted to untreated fruits stored in the same room, rendering them unmarketable as well. In addition to the offensive 
odor, peaches and apples showed surface browning or scald and pears developed internal breakdown.

Shell OS-840 (CBP-55). Shell OS-840, now more commonly called CBP-55, is a proprietary material containing a minimum of 55 per cent chlorobromopropene, most of which is reported to be 1-chloro-3-bromopropene.

TABLE 6

TOLERANCE OF VARIOUS FRUITS TO ETHYL CHLOROACETATE FUMIGATION

\begin{tabular}{|c|c|c|c|c|c|c|}
\hline Commodity & $1 \mathrm{lb}, 2 \mathrm{hrs}$ & $1 \mathrm{lb}, 4 \mathrm{hrs}$ & $2 \mathrm{lbs}, 2 \mathrm{hrs}$ & $2 \mathrm{lbs}, 4 \mathrm{hrs}$ & $4 \mathrm{lbs}, 2 \mathrm{hrs}$ & $4 \mathrm{lbs}, 4 \mathrm{hrs}$ \\
\hline \multicolumn{7}{|l|}{ ApPles } \\
\hline Golden Delicious...... & O & 0 & 0 & 0 & $\ldots$ & $\ldots$ \\
\hline Gravenstein.......... & $\ldots$ & $\ldots$ & 00 & 00 & Oo & 00 \\
\hline Jonathan ............. & 0 & 0 & o & 0 & $\cdots$ & $\ldots$ \\
\hline Red Delicious......... & 0 & o & 0 & 0 & $\ldots$ & $\ldots$ \\
\hline \multicolumn{7}{|l|}{ FIGS } \\
\hline Kadota...$\ldots \ldots \ldots$ & $\mathrm{x}$ & $\ldots$ & $\ldots$ & o & $\ldots$ & $\ldots$ \\
\hline \multicolumn{7}{|l|}{ Grapes } \\
\hline Thompson Seedless... & $\ldots$ & $\ldots$ & o o & 00 & o o & 00 \\
\hline Tokay............... & $\mathbf{x}$ & $\mathbf{x}$ & $\mathbf{x}$ & $\mathbf{x}$ & $\ldots$ & $\ldots$ \\
\hline \multicolumn{7}{|l|}{ NECTARINES } \\
\hline Stanwick & $\ldots$ & $\ldots$ & 0 & $\ldots$ & $\ldots$ & 0 \\
\hline \multicolumn{7}{|l|}{ Peaches } \\
\hline Blood Cling. & o & $\ldots$ & $\ldots$ & 0 & $\ldots$ & $\ldots$ \\
\hline Fay Elberta.. & $\ldots$ & $\ldots$ & 0 & 0 & 0 & 0 \\
\hline 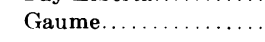 & $\cdots$ & $\cdots$ & o & $\ldots$ & $\ldots$ & 0 \\
\hline \multicolumn{7}{|l|}{ PeARs } \\
\hline Bartlett... & $\ldots$ & $\ldots$ & o & 0 & 0 & 0 \\
\hline Bosc....... & 0 & 0 & 0 & 0 & $\ldots$ & $\ldots$ \\
\hline \multicolumn{7}{|l|}{ Plums } \\
\hline 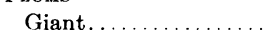 & o & 0 & o o & o o & 0 & 0 \\
\hline Kelsey .............. & $\ldots$ & $\ldots$ & 0 & 0 & 0 & 0 \\
\hline President............ & 0 & 0 & 0 & 0 & $\ldots$ & $\ldots$ \\
\hline
\end{tabular}

$\mathrm{x}=$ Tolerant to treatment.

$0=$ Not tolerant to treatment.

Preliminary trials were made in the 1950 fruit season, using dosages calculated to be $1 / 2,1,2$, and 4 pounds of fumigant per 1,000 cubic feet for 2 and 4 hours. Not all of the treatments were used on all fruits. The following fruit species and varieties were included in the trials: apple-Gravenstein ; fig-Kadota; grape-Thompson Seedless; nectarine-Stanwick; peachBlood Cling, Fay Elberta, Gaume; pear-Bartlett; plum-Diamond, Duarte, Giant, Kelsey, and President.

Serious damage occurred in all fruit varieties at all dosages. Surface browning and scald were the predominant symptoms of injury. Each was accompanied by off-flavor, even on the fruit lots showing the least-serious surface injury. Chlorophyll disappearance was irregular during the ripening of several fruits, rendering the fruit surface splotchy in appearance. It is 
obvious from these results that this material is not adapted to the fumigation of fresh fruits.

Ethyl Chloroacetate. With the exception of Tokay grapes treated with dosages of 1 pound, 2 hours to 2 pounds, 4 hours, and a single lot of Kadota figs treated with a dosage of 1 pound, 2 hours, all fruits were seriously injured (table 6 ). Injury in the form of scald appeared within about 2 days of treatment, increasing in severity with time and dosage and serving as an entrance for decay organisms. Serious off-flavor was also recorded on a large number of lots having scald injury.

The damage to appearance and flavor is so great as to render ethyl chloroacetate unsuitable as a fumigant for fresh fruits.

\section{Group II Fumigants}

Propylene Bromide (1,2-Dibromopropane). There was no visible evidence of injury to the appearance of any fruit species after fumigation with propylene bromide. However, delay in ripening was apparent on certain plum varieties, especially at the 2-pound, 2-hour dosage. In all cases objectionable flavor was noted after treatment with propylene bromide. It would seem that the flavor resulted primarily from absorption of the chemical, since the off-flavor usually disappeared with time. However, in a number of instances the treated fruits never attained the dessert quality of the controls, often because of loss of characteristic aroma.

An evaluation of the potential of propylene bromide for fruit fumigation would have to relate persistence of off-flavor with insecticidal qualities. It is obvious from the data (table 7 ) that even a dosage of 1 pound, 2 hours results in flavor injury to a number of fruit varieties. There are other fumigants of greater insecticidal value that have less persistent flavor effects. By comparison it would seem at this time that propylene bromide holds little promise as a fresh-fruit fumigant.

Trimethylene Bromide. The effectiveness of this chemical on naked eggs and larvae of the Oriental fruit fly, although not so good as that of a number of the fumigants used, appears to be somewhat better than that of methyl bromide because of its greater effectiveness on eggs. Preliminary trials in 1951 were conducted in 5-gallon glass jars, at dosages of 1 pound, 2 hours and 2 pounds, 2 hours, to determine the tolerance of several fruit species to the fumigant. Table 7 summarizes the results at the dosages used.

In only 11 of 132 tests was trimethylene bromide recorded as being noninjurious to flavor. It is obvious from the development of off-flavor in the great majority of the tests that the dosages used were well beyond the safe range. It is also possible that minor flavor effects were not detected in the lots recorded as uninjured. Furthermore, the high boiling point of trimethylene bromide would indicate some difficulty in vaporization, so that the actual dosage to which fruits were exposed may have been somewhat lower than the calculated dosages shown.

Since some of the chemicals tested have more effective insecticidal qualities and less deleterious effects on fruit flavor, trimethylene bromide is not ('onsidered a promising fumigant of fresh fruits. 
TABLE 7

TOLERANCE OF VARIOUS FRUITS TO FUMIGATION

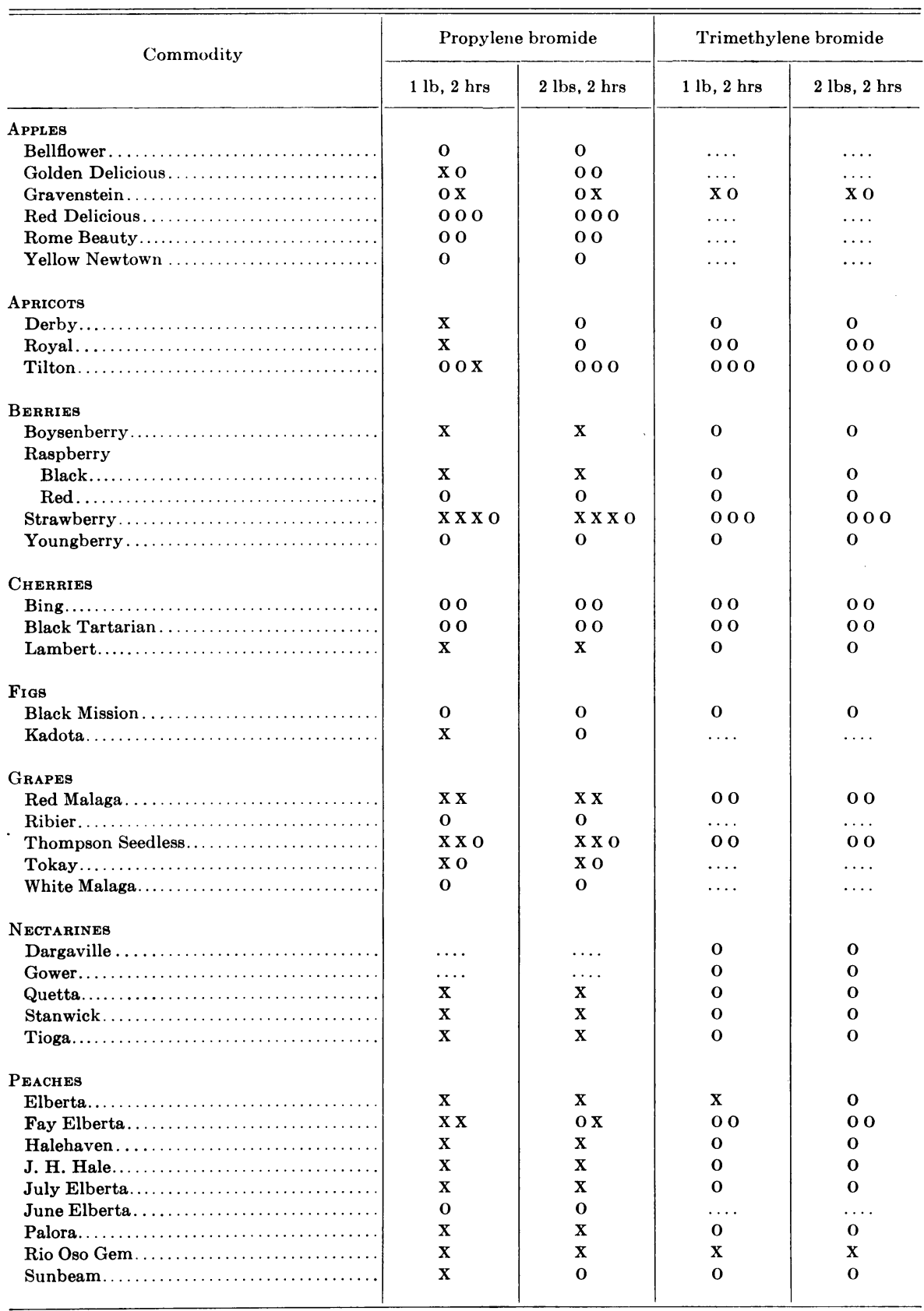

$\mathbf{X}=$ Tolerant to treatment.

$\mathbf{O}=$ Not tolerant to treatment. 
TABLE 7-Continued

\begin{tabular}{|c|c|c|c|c|}
\hline \multirow{2}{*}{ Commodity } & \multicolumn{2}{|c|}{ Propylene bromide } & \multicolumn{2}{|c|}{ Trimethylene bromide } \\
\hline & $1 \mathrm{lb}, 2 \mathrm{hrs}$ & $2 \mathrm{lbs}, 2 \mathrm{hrs}$ & $1 \mathrm{lb}, 2 \mathrm{hrs}$ & $2 \mathrm{lbs}, 2 \mathrm{hrs}$ \\
\hline \multicolumn{5}{|l|}{ Pears } \\
\hline Bartlett.. & $\mathbf{x} \times \mathbf{x} \times$ & $\mathrm{x} \times \mathrm{Ox}$ & $\times \times 00$ & X000 \\
\hline Bosc.......... & $\mathbf{x}$ & $\mathbf{x}$ & O & o \\
\hline Comice.... & $\mathbf{x}$ & $\mathbf{x}$ & $\mathbf{x}$ & $\mathbf{x}$ \\
\hline Hardy $\ldots \ldots \ldots$ & $\mathbf{x}$ & $\mathbf{x}$ & 0 & $\mathbf{0}$ \\
\hline Winter Nelis $\ldots \ldots \ldots \ldots \ldots \ldots \ldots \ldots \ldots$ & $\mathbf{x}$ & $\mathbf{x}$ & $\mathbf{x}$ & $\mathbf{0}$ \\
\hline \multicolumn{5}{|l|}{ Persimmons } \\
\hline Honan Red.. & $\mathbf{o}$ & 0 & $\cdots$ & $\cdots$ \\
\hline \multicolumn{5}{|l|}{ Plums } \\
\hline Beauty $\ldots \ldots \ldots \ldots \ldots \ldots \ldots \ldots \ldots \ldots \ldots \ldots \ldots \ldots \ldots \ldots$ & $\mathbf{0}$ & 0 & $\mathbf{O}$ & $\mathbf{O}$ \\
\hline Becky Smith $\ldots \ldots \ldots \ldots \ldots \ldots \ldots \ldots \ldots$ & $\mathbf{0}$ & o & $\mathbf{0}$ & $\mathbf{0}$ \\
\hline 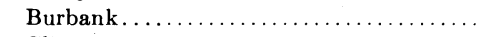 & $\mathbf{x}$ & $\mathbf{x}$ & $\mathbf{o}$ & $\mathbf{o}$ \\
\hline Climax....... & $\mathbf{O x}$ & $\mathrm{ox}$ & 00 & 00 \\
\hline Diamond.... & $\mathbf{x}$ & $\mathbf{x}$ & $\mathbf{0}$ & $\mathbf{o}$ \\
\hline Duarte....... & $\mathbf{x}$ & 0 & o o & o o \\
\hline Earliana...... & $\mathbf{x}$ & $\mathbf{x}$ & $\mathbf{0}$ & $\mathbf{O}$ \\
\hline$\ldots \ldots \ldots \ldots \ldots$ & $\mathbf{0}$ & $\mathbf{0}$ & $\mathbf{O}$ & $\mathbf{0}$ \\
\hline Gaviota...... & $\mathbf{x}$ & $\mathbf{x}$ & $\mathbf{0}$ & $\mathbf{0}$ \\
\hline Giant......... & $\mathbf{x}$ & $\mathbf{x}$ & $\mathbf{0}$ & $\mathbf{O}$ \\
\hline Grand Duke... & $\mathbf{x}$ & $\mathbf{x}$ & 0 & 0 \\
\hline Kelsey ........... & $\mathbf{x}$ & $\mathbf{O}$ & $\mathbf{0}$ & $\mathbf{0}$ \\
\hline$\ldots \ldots \ldots \ldots \ldots \ldots \ldots$ & $\mathbf{x} \mathbf{x}$ & 00 & 00 & 00 \\
\hline Tragedy $\ldots \ldots \ldots \ldots \ldots \ldots \ldots \ldots \ldots \ldots$ & $\ldots$ & $\ldots$ & 0 & $\mathbf{o}$ \\
\hline 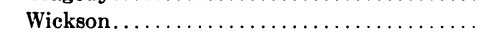 & $\mathbf{x x}$ & $\mathbf{o x}$ & o o & o o \\
\hline
\end{tabular}

$\mathbf{X}=$ Tolerant to treatment.

$0=$ Not tolerant to treatment.

Dow Fume W85 (85 per cent ethylene dibromide, 15 per cent petroleum fraction). Although this proprietary compound is 85 per cent ethylene dibromide, results of many tests indicate that it is more damaging to fruits, both in flavor and appearance, than is ethylene dibromide. This would indicate that the petroleum fraction was either directly responsible for the greater injury or caused more ethylene dibromide to be retained in the fruit. Chemical analyses to settle the question were not attempted.

Because of the somewhat better results when ethylene dibromide was used alone, studies with Dow Fume W85 were abandoned after preliminary trials.

\section{Group III Fumigants}

Five chemicals are listed in Group III: chlorasol, methyl bromide, methyl iodide, ethylene chlorobromide, and ethylene dibromide. Of these, the first 3 do not fit the definition of either Group II or Group III but are intermediate between the 2. Perhaps chlorasol should be in an entirely separate category. It was the least harmful to fruit of any chemical tested, but is required in such high concentrations to be lethal to larvae that entomological studies with it in Hawaii were discontinued.

Methyl bromide has been used successfully as a fumigant of fresh fruits for several years, but the high dosage required for Oriental and other fruit flies caused it to fall into Group II in some instances. 
Detailed entomological information is not available on dosage requirements of methyl iodide. This chemical is arbitrarily listed as intermediate between Groups II and III for this reason. Ethylene dibromide and ethylene chlorobromide come the nearest to complying with the definition of Group III fumigants.

Chlorasol (25 per cent carbon tetrachloride, 75 per cent ethylene dichloride) (Groups II and III). Information originally received indicated that this mixture is effective against naked eggs of the Oriental fruit fly. Studies of commodity tolerances were well under way when a further report from Hawaii showed that chlorasol was comparatively ineffective against naked larvae $\left(\mathrm{LD}_{95}\right.$-more than $140 \mathrm{mg}$ per liter $)$.

Although chlorasol is not sufficiently toxic to both eggs and larvae to serve as an effective fumigant, a summary of the information so far collected seems worthy of presentation because of the high degree of tolerance of fruits exposed to it. Calculated dosages ranging from 6 to 20 pounds per 1,000 cubic feet were used. However, it is extremely doubtful that actual concentrations ever attained the calculated levels in the upper range.

Tilton apricots and Golden Jubilee and July Elberta peaches developed scald when treated with calculated concentrations as high as 20 pounds, and Sunbeam peaches showed scald at dosages of 15 pounds, 6 hours and 20 pounds, 6 hours. The only persimmon variety tested, Hachiya, showed a slight surface discoloration when treated with dosages of 12 pounds for 4 , 5 , and 6 hours. Of 8 varieties of plums treated, scald appeared on only one (Giant), and this at the 12-pound concentration. Red Delicious apples also showed an external discoloration and scald on the calyx end when treated with concentrations of 12 pounds for 5 and 6 hours. All other fruit species, including berries, cherries, figs, grapes, and pears, that were treated with this fumigant were not affected in internal or external appearance or flavor.

Methyl Bromide (Groups II and III). At the time studies were begun on potential commodity treatments, methyl bromide, the only promising fumigant known, had been approved for use only with vanda orchids. Previous investigations in Hawaii (Jones, 1940b) had indicated that methyl bromide was unsuitable for papayas because latent anthracnose infections became active decay spots following fumigation. Methyl bromide has been used as a fumigant since the late 1930's, both as a control measure and as a quarantine treatment. It was used in California prior to the development of DDT as a fumigant of packed Bartlett pears for the control of codling moth eggs and larvae that were too small to be detected in sorting operations but capable of developing under transit conditions. Methyl bromide was also used as a treatment in California in connection with quarantine regulations for the tomato pinworm and the potato tuber moth. The specified dosage was 2 pounds per 1,000 cubic feet of space for 2 hours at about $70^{\circ} \mathrm{F}$. Dosage requirements in relation to quarantine of hosts of the Oriental fruit fly were considered to be 2 pounds per 1,000 cubic feet of space for an exposure period of at least 4 hours. This dosage was somewhat more drastic than any heretofore used in California or in any other state.

During 1939, 1940, and 1941, tests were conducted to determine the influ- 
ence of methyl bromide fumigation on Bartlett pears and certain other fruits (Claypool, 1940, 1941). Some of the data resulting from these tests are presented in this report.

In 1940, Bartlett pears from 5 different orchards along the Sacramento River were harvested July 23 to 25 . Half of the fruits were fumigated with methyl bromide at a dosage of 2 pounds, 2 hours. Subsequently, comparable lots of treated and untreated fruits were ripened following different storage treatments and compared for dessert quality. Results are shown in table 8 .

In a subjective test of this nature less attention should be paid to apparent differences between different storage periods than to differences between

TABLE 8

INFLUENCE OF METHYL BROMIDE FUMIGATION UPON FLAVOR OF BARTLETT PEARS, 1940

\begin{tabular}{|c|c|c|c|c|c|c|c|c|}
\hline \multirow{2}{*}{ Orchard } & \multicolumn{2}{|c|}{$\begin{array}{c}\text { Ripened } \\
\text { immediately }\end{array}$} & \multicolumn{2}{|c|}{$42^{\circ} \mathrm{F} 2$ weeks } & \multicolumn{2}{|c|}{$31^{\circ} \mathrm{F} 1$ month } & \multicolumn{2}{|c|}{$31^{\circ}$ F 2 months } \\
\hline & Check & Treated & Check & Treated & Check & Treated & Check & Treated \\
\hline $1 \ldots$ & $\mathrm{G}$ & F-G & F & $\mathbf{F}$ & $\mathbf{P}$ & $\mathrm{P}-\mathrm{VP}$ & $\mathbf{F}$ & $\mathrm{P}$ \\
\hline $2 \ldots \ldots \ldots$ & $\mathbf{F}$ & $\mathbf{P}-\mathbf{F}$ & F & $\mathbf{P}$ & $P$ & $\mathrm{P}$ & $\mathbf{F}$ & VP \\
\hline $3 \ldots \ldots \ldots \ldots$ & $\mathrm{G}$ & $\mathrm{P}$ & $\mathrm{G}$ & $\mathbf{P}$ & G & $\mathrm{P}-\mathrm{G}$ & $\mathbf{F}$ & $\mathbf{P}$ \\
\hline $4 \ldots \ldots$ & $\mathrm{G}$ & $\mathrm{P}-\mathrm{G}$ & F-G & $\mathbf{F}$ & G & $\mathbf{P}-\mathbf{F}$ & $\mathbf{F}$ & $\mathbf{F}$ \\
\hline $5 \ldots \ldots$ & G & $\mathbf{F}$ & $P$ & $\mathrm{P}$ & F-G & $\mathrm{P}-\mathrm{G}$ & $\mathbf{F}$ & $\mathbf{F}$ \\
\hline
\end{tabular}

$(i=\operatorname{good}$

$\mathrm{F}=$ fair

$\mathrm{VP}=$ very poor

comparably treated and untreated lots of fruit. In no case was the fumigated fruit recorded as being of better dessert quality than the control fruit. However, in 15 out of 20 comparisons the untreated fruit was recorded as being of better flavor than that fumigated with methyl bromide. Differences were often small and probably would not be detected by the layman. No visible effects of fumigation were observed from a dosage of 2 pounds, 2 hours, except for a slight acceleration of ripening.

Some studies were also made to determine the influence of treatment time and methyl bromide concentration upon dessert quality. Table 9 summarizes the results of these studies.

These results indicate that the flavor of most fruits was damaged by all fumigant dosages. Delicious apples, which seemed fairly tolerant insofar as flavor was concerned, developed flesh browning at dosages above 2 pounds, 2 hours. This is in agreement with reports of Phillips and Monro (1939), and Kenworthy and Gaddis (1946), which showed certain apple varieties to be fairly susceptible to methyl bromide injury.

These earlier studies also showed that methyl bromide was physiologically active. This was demonstrated by its effect on the ripening of fruits. Certain fruits (including pears, apples, and some plum varieties) ripened more rapidly than normal after fumigation with dosages up to 2 pounds, 2 hours. When higher dosages (such as 4 pounds, 2 hours) were used, the same fruits were delayed in ripening. Tomatoes were similarly influenced, and reduced 
in vitality, as indicated by an increased susceptibility to the attack of decay organisms (Knott and Claypool, 1940; Morris and Claypool, 1942). That the effect from low dosages was not comparable to an ethylene effect was demonstrated in a test on the loosening of hulls of walnuts. With ethylene, a 24-hour exposure is usually sufficient to loosen the hull, whereas such exposure to methyl bromide seemed to cause the hull to stick even more tightly than normal. Methyl bromide was also found to influence red pigmentation in the

TABLE 9

INFLUENCE OF METHYL BROMIDE FUMIGATION UPON FLAVOR AND CONDITION OF SEVERAL FRUITS, 1940

\begin{tabular}{|c|c|c|c|c|c|c|}
\hline \multirow{2}{*}{ Fruit } & \multicolumn{6}{|c|}{ Fumigation treatment } \\
\hline & $\begin{array}{c}\text { Untreated } \\
\text { control }\end{array}$ & $1 \mathrm{lb}, 4 \mathrm{hrs}$ & $2 \mathrm{lbs}, 2 \mathrm{hrs}$ & $2 \mathrm{lbs}, 4 \mathrm{hrs}$ & $4 \mathrm{lbs}, 1 \mathrm{hr}$ & $4 \mathrm{lbs}, 2 \mathrm{hrs}$ \\
\hline Early Crawford peach. & G & P-F & $\mathbf{F}$ & $\mathbf{P}$ & P-F & $\mathbf{P}$ \\
\hline Ansenne nectarine.. & G & F-G & $\mathbf{F}$ & $\mathbf{P}$ & $\mathbf{P}$ & $\mathrm{P}$ \\
\hline Bartlett pear.. & G & $\ldots$ & F-G & $\mathbf{F}$ & F-G & $\mathbf{P}$ \\
\hline $\begin{array}{l}\text { Delicious apple........... } \\
\text { (ripened immediately) }\end{array}$ & G & $\ldots$ & G (riper) & $\mathbf{F}$ (riper) & $\begin{array}{l}\mathrm{P} \text { (browning } \\
\text { vas. bundles) }\end{array}$ & $\begin{array}{l}P \text { (browning } \\
\text { vas. bundles } \\
\text { and flesh) }\end{array}$ \\
\hline $\begin{array}{l}\text { Delicious apple........ } \\
\text { (ripened after } 51 / 2 \mathrm{mo} . \\
\text { at } 32^{\circ} \mathrm{F} \text { ) }\end{array}$ & G & $\ldots$ & G & $\begin{array}{c}\text { G (flesh } \\
\text { browning and } \\
\text { scald } 10 \text { days } \\
\text { after storage) }\end{array}$ & $\begin{array}{l}\mathrm{P} \text { (flesh } \\
\text { browning) }\end{array}$ & $\begin{array}{l}\mathrm{P} \text { (flesh } \\
\text { browning) }\end{array}$ \\
\hline
\end{tabular}

$\mathrm{G}=\operatorname{good}$

$\mathbf{F}=$ fair
$\mathbf{P}=$ poor

skins of peaches and nectarines. Certain varieties of these fruits were greatly enhanced in color after exposure to a dosage of 2 pounds, 4 hours or somewhat similar dosages (Claypool, 1940). Red pigmentation of excellent quality was greatly increased during a 4-to-5-day period following treatment. Light was not required. Unfortunately, flavor was so seriously impaired that color enhancement by exposure to methyl bromide has not been put to commercial use. However, the influence on pigmentation is an indication that methyl bromide reacts chemically within the fruit, perhaps as a methylating agent.

With this information at hand, extensive trials were made with methyl bromide on a large number of fruit species and varieties during the 1949, 1950, and 1951 fruit seasons. During 1949, 2 pounds for 4 hours was the only dosage used; this was considered the minimum that might be approved for Oriental fruit fly quarantine treatment. In 1950 a range of dosages was tested to determine the tolerance level of the fruit. Most of the 1950 trials were made in 5-gallon glass containers, where the 1949 and 1951 trials were all made in the walk-in fumigation chambers. Table 10 summarizes the tolerance data without indicating reasons for the failure of fruits to tolerate any particular treatment. 
In 1949 all varieties of apples were damaged except for 5 of the 10 lots of Yellow Newtowns treated. Accentuation of bruises and scald and external browning contributed the most obvious damage. Slight damage was recorded in 1950, and none in 1951, on the varieties tested.

Derby and one lot of Royal apricots had off-flavors but Tilton was not affected in 1950. None of these 3 varieties was injured in 1951.

Boysenberries and raspberries were not affected by treatments in 1950 or 1951, but the flavor of 4 different varieties of strawberries was adversely affected, resulting in a loss of aroma.

All varieties of cherries, except Bing and Burbank, showed a color retardation at a dosage of 2 pounds, 2 hours. Surface browning occurred in some varieties in 1950. The fruit treated in 1951 showed no ill effect from treatments.

Figs withstood the treatment of 2 pounds, 2 hours in 1950 and 1951. In all three years treatments of 2 pounds, 4 hours and above caused external breakdown and dark-colored, rubbery tissue; it also caused an exudation from the ostiole of Kadota figs.

Emperor grapes treated with the dosage of 2 pounds, 4 hours in 1949 seemed to be slightly off-color and off-flavor; Tokay grapes showed no damage. In 1950 and 1951 grapes withstood treatments of as high as 2 pounds, 4 hours without damage, but injury was recorded in 1950 from dosages of 3 pounds, 2 hours or 4 pounds, 2 hours.

Nectarines withstood the lower treatments of 2 pounds, 2 hours and 2 pounds, 3 hours without ill effect in 1950, but off-flavor was noted at higher dosages. None of the varieties tested in 1951 was injured at dosages as high as 2 pounds, 4 hours.

In 1950, damage to flavor was recorded in several peach varieties treated with dosages of methyl bromide greater than 2 pounds for 2 hours when treatments were conducted in jars. However, no injury was recorded in 1951 on fruit treated in the chamber with concentrations as high as 2 pounds, 4 hours.

Damage to pears was recorded in 1949 on all lots receiving a dosage of 2 pounds, 4 hours, the only treatment used. Ripening was delayed and abnormal, and flavor was impaired. In 1950 no damage was recorded at concentrations of 2 pounds, 4 hours, but some injury was noted at concentrations of 3 and 4 pounds. In 1951, 2 lots of Bartlett pears out of 10 lots treated were listed as injured.

In 1949, 1950, and 1951, abnormal ripening was induced in nearly all the varieties of persimmons tested. Tough exocarp and a dark-brown flesh were characteristic of all treated fruit.

There was considerable variability in the response of plums to treatments with methyl bromide. Even the same variety from 2 different areas might give different results. Tolerance results indicate that methyl bromide can be used safely for most California-grown fruits at dosages up to 2 pounds per 1,000 cubic feet of space for 2 hours at 70 to $80^{\circ} \mathrm{F}$. When treatment time is increased to 4 hours, the fumigant does not appear to be safe. Tolerance at this dosage seems to be variable with the source of fruit and year, so there is no assurance that damage will not result. Even with the most tolerant fruit species the margin of safety is considered too small to warrant commercial 
TABLE 10

TOLERANCE OF VARIOUS FRUITS TO METHYL BROMIDE FUMIGATION

\begin{tabular}{|c|c|c|c|c|c|c|c|}
\hline \multirow{2}{*}{ Commodity } & \multicolumn{5}{|c|}{1950} & \multicolumn{2}{|c|}{1951} \\
\hline & $2 \mathrm{lbs}, 2 \mathrm{hrs}$ & $2 \mathrm{lbs}, 3 \mathrm{hrs}$ & $2 \mathrm{lbs}, 4 \mathrm{hrs}$ & $3 \mathrm{lbs}, 2 \mathrm{hrs}$ & $4 \mathrm{lbs}, 2 \mathrm{hrs}$ & $2 \mathrm{lbs}, 2 \mathrm{hrs}$ & $2 \mathrm{lbs}, 4 \mathrm{hrs}$ \\
\hline \multicolumn{8}{|l|}{ ApPles } \\
\hline Bellflower. & $\ldots$ & $\ldots$ & $\ldots$ & $\ldots$ & $\ldots$ & $\mathbf{x}$ & $\mathbf{x}$ \\
\hline Golden Delicious.... & $\mathbf{x}$ & $\mathbf{x}$ & $\mathbf{X} \mathrm{X}^{*}$ & $\mathbf{x}$ & 0 & $\mathbf{x x}$ & $\mathrm{X} \mathrm{X}$ \\
\hline Gravenstein......... & $\mathbf{x} \mathbf{x}$ & $\mathbf{x}$ & $\mathbf{x} \mathbf{x}$ & 0 & o & $\mathbf{X X}$ & $\mathbf{X X}$ \\
\hline Jonathan ........... & $\mathbf{X}$ & O & 0 & 0 & o & $\mathbf{x}$ & $\mathrm{X}$ \\
\hline Red Delicious....... & $\mathbf{x}$ & $\mathbf{x}$ & $\mathrm{X} \mathrm{O}^{*}$ & o & o & $\mathbf{x} \times \mathbf{x}$ & $\times 1 \times 0$ \\
\hline Rome Beauty ........ & $\cdots$ & $\cdots$ & $\begin{array}{l}\mathrm{O}^{*}(50 \% \mathrm{red}) \\
\mathrm{X}^{*}(\text { full red })\end{array}$ & $\ldots$ & $\cdots$ & $\mathrm{x}$ & $\mathbf{x}$ \\
\hline Winesap.......... & $\ldots$ & $\ldots$ & $\ldots$ & $\ldots$ & $\ldots$ & $\mathbf{x}$ & $\mathbf{x}$ \\
\hline White Astrachan.... & $\mathbf{x}$ & $\mathrm{x}$ & $\mathbf{x}$ & $\mathbf{x}$ & 0 & & $\ldots$ \\
\hline Yellow Newtown.... & $\cdots$ & $\ldots$ & $\mathrm{X}^{*}$ & $\ldots$ & $\cdots$ & $\mathrm{xx}$ & $\mathrm{x} \mathrm{X}$ \\
\hline \multicolumn{8}{|l|}{ ApRICOTs } \\
\hline Derby... & 0 & 0 & 0 & o & 0 & $\mathbf{x} \mathbf{x}$ & $\mathbf{x} \mathbf{x}$ \\
\hline Royal... & Xo & X 0 & x O & Xo & Xo & $\mathbf{x x}$ & $\mathbf{x} \mathbf{x}$ \\
\hline Tilton.......... & $\mathbf{x}$ & $\mathbf{x}$ & $\mathbf{x}$ & $\mathbf{x}$ & $\mathbf{x}$ & $\mathbf{x} \times \mathbf{x}$ & $\mathbf{x} \times \mathbf{x}$ \\
\hline \multicolumn{8}{|l|}{ BerRies } \\
\hline Boysenberry ........ & $\mathrm{X} \mathrm{X}^{*}$ & $\mathbf{x}$ & $\mathbf{x}$ & $\mathrm{x}$ & $\mathrm{X} \mathrm{X}^{*}$ & $\mathbf{x}$ & $\mathbf{x}$ \\
\hline Raspberry.......... & $\mathbf{x}$ & $\mathbf{x}$ & $\mathbf{x}$ & $\mathbf{x}$ & $\mathbf{X}$ & $\ldots$ & $\ldots$. \\
\hline Black.............. & $\ldots$ & $\ldots$ & $\ldots$ & $\ldots$ & $\ldots$ & $\mathbf{x}$ & $\mathbf{x}$ \\
\hline $\operatorname{Red} \ldots \ldots \ldots \ldots$ & $\ldots$. & $\ldots$ & $\ldots$ & $\ldots$ & $\ldots$ & $\mathbf{X}$ & 0 \\
\hline Strawberry . . . . . . & $\ldots$ & $\ldots$ & $\ldots$ & $\ldots$ & $\ldots$ & $\mathbf{X}$ & $\mathbf{x}$ \\
\hline Donner........ & 00 & 00 & 00 & 00 & 00 & $\ldots$ & $\ldots$ \\
\hline Lassen............... & 0 & o & 0 & 0 & 0 & $\cdots$ & $\cdots$ \\
\hline Shasta........... & o & o & o & o & o & $\ldots$ & $\cdots$ \\
\hline Youngberry .......... & $\cdots$ & $\cdots$ & $\ldots$ & $\cdots$ & $\ldots$ & $\cdots$ & $\ddot{o}$ \\
\hline \multicolumn{8}{|l|}{ Cherries } \\
\hline Bing..... & $\mathbf{x} \mathbf{x}$ & $\mathbf{x x}$ & $\mathbf{x} \mathbf{x}$ & $\mathbf{x} \mathbf{x}$ & $\mathbf{x x}$ & $\mathrm{x} \mathrm{X}$ & $\mathbf{x} \mathbf{x}$ \\
\hline Black Tartarian.... & OO & 0 & 0 & 0 & 0 & $\mathrm{x}$ & $\mathbf{x}$ \\
\hline Burbank........... & $\mathbf{x}$ & $\mathbf{x}$ & $\mathbf{x}$ & $\mathbf{x}$ & 0 & $\ldots$ & $\ldots$ \\
\hline Chapman........... & O & O & o & o & O & & $\ldots$ \\
\hline Lambert........... & $\ldots$ & $\ldots$ & $\cdots$ & $\cdots$ & $\ldots$ & $\mathbf{x}$ & $\mathbf{x}$ \\
\hline Royal Ann......... & o & 0 & 0 & 0 & 0 & $\ldots$ & $\ldots$ \\
\hline \multicolumn{8}{|l|}{ Figs } \\
\hline Black Mission....... & $\ldots$ & $\ldots$ & $\ldots$ & $\cdots$ & $\ldots$ & $\mathrm{x}$ & 0 \\
\hline Kadota........... & $\mathbf{x}$ & $\mathbf{x}$ & 0 & 0 & 0 & $\mathbf{x}$ & 0 \\
\hline \multicolumn{8}{|l|}{ Grapes } \\
\hline Emperor. & $\mathrm{X}^{*} \mathrm{X}^{*}$ & $\ldots$ & $\mathbf{X}^{*} \mathbf{X}^{*} \mathbf{X}^{*}$ & $\ldots$ & $\ldots$ & $\mathbf{X}$ & $\mathbf{X}$ \\
\hline Red Malaga.... & $\ldots$ & $\ldots$ & $\ldots$ & $\ldots$ & $\ldots$ & $\mathbf{X X}$ & $\mathrm{x} \mathrm{X}$ \\
\hline Ribier.............. & $\ldots$ & $\ldots$ & $\ldots$ & $\ldots$ & $\ldots$ & $\mathbf{x}$ & $\mathbf{x}$ \\
\hline Thompson Seedless. & $\mathbf{X X}$ & $\mathrm{x}$ & $\mathrm{X} \mathrm{X} \mathrm{X*}$ & 0 & 0 & $\mathbf{x} \times \mathbf{x}$ & $\mathbf{x} \times \mathbf{x}$ \\
\hline Tokay............... & $\mathbf{X}$ & $\mathbf{X}$ & $\mathrm{XX}^{*}$ & o & 0 & 000 & 000 \\
\hline White Malaga........ & $\ldots$ & $\cdots$ & $\ldots$ & $\ldots$ & $\ldots$ & $\mathrm{x}$ & $\mathrm{x}$ \\
\hline \multicolumn{8}{|l|}{ Nectarines } \\
\hline Dargaville.... & $\ldots$ & & $\ldots$ & $\ldots$ & $\ldots$ & $\mathbf{x}$ & $\mathbf{x}$ \\
\hline Early River. ....... & $\mathbf{x}$ & $\mathbf{x}$ & $\mathbf{O}$ & 0 & 0 & $\ldots$ & $\ldots$. \\
\hline Gower...... & $\cdots$ & $\ldots$ & $\ldots$ & $\cdots$ & $\cdots$ & $\mathbf{x}$ & $\mathrm{x}$ \\
\hline John River........ & $\mathbf{x}$ & $\mathbf{x}$ & $\mathbf{x}$ & 0 & 0 & $\ldots$ & $\ldots$ \\
\hline Philp............. & $\mathrm{x}$ & $\mathbf{x}$ & $\mathbf{x}$ & 0 & 0 & $\ldots$ & $\ldots$ \\
\hline
\end{tabular}

* 1950 tests conducted in walk-in type chamber.

$\left.\begin{array}{l}\mathrm{X}=\text { Tolerant to treatment } \\ ()=\text { Not tolerant to treatment }\end{array}\right\}$ Repetition indicates additional tests. 
TABLE 10-Continued

\begin{tabular}{|c|c|c|c|c|c|c|c|}
\hline \multirow{2}{*}{ Commodity } & \multicolumn{5}{|c|}{1950} & \multicolumn{2}{|c|}{1951} \\
\hline & $2 \mathrm{lbs}, 2 \mathrm{hrs}$ & $2 \mathrm{lbs}, 3 \mathrm{hrs}$ & $2 \mathrm{lbs}, 4 \mathrm{hrs}$ & $3 \mathrm{lbs}, 2 \mathrm{hrs}$ & $4 \mathrm{lbs}, 2 \mathrm{hrs}$ & $2 \mathrm{lbs}, 2 \mathrm{hrs}$ & $2 \mathrm{lbs}, 4 \mathrm{hrs}$ \\
\hline \multicolumn{8}{|l|}{ Nectarines-cont. } \\
\hline Quetta............. & $\cdots$ & $\ldots$ & $\ldots$ & $\ldots$ & $\ldots$ & $\mathrm{x}$ & $\mathrm{x}$ \\
\hline Stanwick........... & $\mathbf{x}$ & $\ldots$ & 0 & $\ldots$ & $\ldots$ & $\mathrm{x}$ & $\mathrm{x}$ \\
\hline Tioga $\ldots \ldots \ldots \ldots$ & $\cdots$ & $\cdots$ & $\cdots$ & $\cdots$ & $\cdots$ & $\mathrm{x}$ & $\mathrm{x}$ \\
\hline \multicolumn{8}{|l|}{ Peaches } \\
\hline Alexandria.......... & $\mathbf{x}$ & $\mathbf{x}$ & $\mathbf{x}$ & $\mathbf{x}$ & $\mathrm{x}$ & $\ldots$ & $\cdots$ \\
\hline Babcock.......... & $\mathbf{X}$ & $\mathbf{x}$ & $\mathbf{x}$ & $\mathbf{X}$ & $\mathbf{x}$ & $\ldots$ & $\ldots$ \\
\hline Blood Cling.... & $\mathbf{x}$ & $\cdots$ & $\mathbf{x}$ & $\cdots$ & $\ldots$ & $\ldots$ & \\
\hline Elberta........... & $\ldots$ & $\ldots$ & $\ldots$ & $\ldots$ & $\cdots$ & $\mathrm{x}$ & $\mathrm{x}$ \\
\hline Fay Elberta ........ & $\mathbf{x}$ & $\mathrm{x}$ & 0 & 0 & 0 & $\mathrm{x} x$ & $\mathrm{x} \mathrm{x}$ \\
\hline Gaume........... & $\mathbf{x}$ & $\ldots$ & 0 & $\ldots$ & $\ldots$ & . & . . \\
\hline Halehaven......... & $\mathbf{x}$ & $\mathbf{x}$ & $\mathrm{x}$ & $\mathrm{x}$ & $\mathrm{x}$ & $x$ & $\mathrm{x}$ \\
\hline J. H. Hale.......... & $\ldots$ & $\cdots$ & $\ldots$ & $\ldots$ & .. & $\mathrm{x}$ & $\mathrm{x}$ \\
\hline July Elberta......... & $\mathrm{x}$ & 0 & 0 & 0 & 0 & $\mathrm{x}$ & $\mathrm{x}$ \\
\hline June Elberta . . . . . . & $\ldots$. & $\ldots$ & $\ldots$ & $\ldots$ & $\ldots$ & $\mathrm{x}$ & $\mathrm{x}$ \\
\hline Kirkman.......... & $\mathrm{x}$ & $\mathrm{x}$ & $x$ & $x$ & $\mathrm{x}$ & $\ldots$ & $\ldots$ \\
\hline Palora......... & $\cdots$ & $\ldots$ & $\ldots$ & $\ldots$ & $\ldots$ & $\mathbf{x}$ & $\ldots$ \\
\hline Rio Oso Gem......... & $\ldots$ & $\ldots$ & $\ldots$ & $\ldots$ & $\ldots$ & $\mathrm{x}$ & $\mathrm{x}$ \\
\hline Sunbeam........... & $\mathbf{x}$ & $\mathrm{x}$ & $\mathrm{x}$ & $\mathrm{x}$ & $\mathrm{x}$ & $\mathrm{x} \mathrm{x}$ & $\mathrm{x} \mathrm{x}$ \\
\hline \multicolumn{8}{|l|}{ Pears } \\
\hline Bartlett. . & $\mathbf{x} \mathbf{x} \mathbf{x} \mathbf{x} \mathbf{x} \mathbf{x}$ & $\mathbf{x} \times \mathbf{x} \times \mathbf{x}$ & $\mathbf{x} \times \mathbf{x} \times \mathbf{x} \times$ & 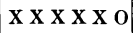 & $\mathbf{x} \times \mathbf{x} \times \mathbf{x} 0$ & $\mathrm{x} \times \mathrm{x} \times \mathrm{x}$ & $\times \times \times 00$ \\
\hline Bosc............... & $\mathrm{x}$ & $\mathrm{x}$ & $\mathrm{x}$ & 0 & 0 & $\mathrm{x}$ & $\mathrm{X}$ \\
\hline Comice........... & $\ldots$ & $\ldots$ & $\ldots$ & $\ldots$ & $\ldots$ & $\mathrm{x}$ & $\mathrm{X}$ \\
\hline Hardy...$\ldots \ldots \ldots$ & $\cdots$ & $\ldots$ & $\ldots$ & $\ldots$ & $\cdots$ & $\mathrm{x}$ & $\mathrm{x}$ \\
\hline Winter Nelis. . & $\cdots$ & $\cdots$ & $\mathrm{X}^{*}$ & $\cdots$ & $\cdots$ & $\mathbf{x}$ & $\mathrm{x}$ \\
\hline \multicolumn{8}{|l|}{ Persimmons } \\
\hline Fuyu...... & ... & $\ldots$ & $0^{*} 0^{*}$ & $\ldots$ & $\ldots$ & $\cdots$ & $\ldots$ \\
\hline Fuji........ & ... & $\ldots$ & $\ldots$ & $\ldots$ & $\ldots$ & 0 & 0 \\
\hline Hachiya............ & $\cdots$ & $\ldots$ & $\mathrm{O}^{*}$ & $\ldots$ & $\ldots$ & $\mathrm{x}$ & $\mathrm{x}$ \\
\hline Honan Red.......... & $\ldots$ & $\cdots$ & $\ldots$ & $\ldots$ & $\ldots$ & 0 & 0 \\
\hline Nishirazu.......... & $\cdots$ & $\cdots$ & $\cdots$ & $\cdots$ & $\ldots$ & 0 & 0 \\
\hline Tamopan........... & $\cdots$ & $\cdots$ & $\mathrm{O}^{*}$ & $\cdots$ & $\cdots$ & $\cdots$ & $\cdots$ \\
\hline \multicolumn{8}{|l|}{ Plums } \\
\hline American........... & $\ldots$ & $\ldots$ & o & $\ldots$ & $\ldots$ & $\ldots$ & $\ldots$ \\
\hline 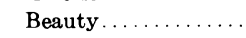 & $\mathrm{X} \times \mathrm{X}$ & $\mathbf{x} \times \mathbf{x}$ & $\times \times 0$ & $\times \times 0$ & $\mathrm{x} \times 0$ & $\mathrm{x}$ ox & $00 x$ \\
\hline Becky Smith....... & $\cdots$ & $\ldots$ & $\cdots$ & $\ldots$ & $\ldots$ & 0 & 0 \\
\hline Burbank........... & $\ldots$ & $\cdots$ & $\ldots$ & $\ldots$ & $\ldots$ & $\mathrm{x}$ & 0 \\
\hline $\operatorname{Climax} \ldots \ldots \ldots \ldots$ & 0 & 0 & o & 0 & 0 & $\mathrm{xx}$ & $O x$ \\
\hline Diamond.......... & $\cdots$ & . & . & . & $\ldots$ & $\mathbf{x}$ & $x$ \\
\hline Duarte............ & 0 & 0 & 0 & 0 & 0 & $\mathrm{x} \mathrm{x}$ & $\mathrm{x} \mathrm{x}$ \\
\hline Earliana........... & $\ldots$ & $\cdots$ & $\ldots$ & $\ldots$ & $\ldots$ & $\mathrm{x}$ & $\mathrm{x}$ \\
\hline Formosa........... & $\mathrm{ox}$ & $\mathbf{0}$ & 0 & o & 0 & $\mathbf{x}$ & 0 \\
\hline Gaviota.......... & $\cdots$ & $\ldots$. & $\ldots$ & ... & $\ldots$ & $\mathrm{x}$ & $\mathrm{x}$ \\
\hline Giant............. & $\mathbf{x}$ & $\mathbf{x}$ & $\mathbf{x}$ & $\mathbf{x}$ & 0 & $\mathrm{x}$ & $\mathrm{x}$ \\
\hline Grand Duke......... & $\cdots$ & … & $\ldots$ & $\ldots$ & $\ldots$ & $\mathrm{x}$ & $\mathrm{x}$ \\
\hline Kelsey ............ & $\ldots$ & $\ldots$ & $\ldots$ & $\ldots$ & $\ldots$ & $\mathrm{x}$ & 0 \\
\hline President....... & $\mathbf{x}$ & $\mathbf{x}$ & $\mathbf{x}$ & $\mathbf{0}$ & o & & \\
\hline Santa Rosa. . & $\mathbf{x}$ & $\mathbf{x}$ & $\mathbf{x}$ & $\mathbf{x}$ & $\mathbf{x}$ & $\mathrm{x} \mathrm{X}$ & $\mathrm{x} x$ \\
\hline Tragedy............ & $\mathbf{x}$ & o & 0 & o & 0 & $\ldots$ & $\ldots$ \\
\hline Wickson. . & $\mathbf{x} \times \mathbf{x} \mathbf{x}$ & $\mathbf{x} \times \mathbf{x}$ & $\mathbf{x} \times \mathbf{x}$ & $\mathbf{x} \times \mathbf{x}$ & $\mathbf{x} \times \mathbf{x} \times$ & $O \times x$ & $0 \times x$ \\
\hline
\end{tabular}

* 1950 tests conducted in walk-in type chamber.

$\left.\begin{array}{l}\mathbf{x}=\text { Tolerant to treatment } \\ 0=\text { Not tolerant to treatment }\end{array}\right\}$ Repetition indicates additional tests, 
TABLE 11

TOLERANCE OF VARIOUS FRUITS TO METHYL IODIDE FUMIGATION

\begin{tabular}{|c|c|c|c|c|c|c|}
\hline \multirow{2}{*}{ Commodity } & \multicolumn{4}{|c|}{1950} & \multicolumn{2}{|c|}{1951} \\
\hline & $1 \mathrm{lb}, 2 \mathrm{hrs}$ & $1 \mathrm{lb}, 4 \mathrm{hrs}$ & $2 \mathrm{lbs}, 2 \mathrm{hrs}$ & $2 \mathrm{lbs}, 4 \mathrm{hrs}$ & $2 \mathrm{lbs}, 2 \mathrm{hrs}$ & $2 \mathrm{lbs}, 4 \mathrm{hrs}$ \\
\hline \multicolumn{7}{|l|}{ APPLES } \\
\hline Bellflower.......... & $\cdots$ & $\ldots$ & $\ldots$ & $\ldots$ & $\mathbf{x}$ & $\mathbf{0}$ \\
\hline Golden Delicious................ & $\mathbf{x} \mathbf{x}$ & X O & $\mathrm{ox}$ & 00 & $\mathbf{x x}$ & o o \\
\hline Gravenstein........ & $\ldots$ & $\ldots$ & $\ldots$ & $\ldots$ & x o & 00 \\
\hline Jonathan.............. & $\mathbf{x}$ & $\mathbf{O}$ & $\mathbf{0}$ & $\mathbf{0}$ & $\cdots$ & $\ldots$ \\
\hline Red Delicious................ & $\mathbf{x} \times$ & $\mathbf{0}$ & 00 & $\mathbf{0}$ & $\mathbf{x} \times \mathbf{x}$ & $0 \times 0$ \\
\hline Rome Beauty $\ldots \ldots \ldots \ldots \ldots \ldots$ & $\mathbf{x}$ & o & $\mathbf{0}$ & $\mathbf{0}$ & $\begin{array}{l}0 \text { (early) } \\
\mathrm{X} \text { (late) }\end{array}$ & 00 \\
\hline Yellow Newtown . & $\mathbf{x}$ & $\mathbf{x}$ & $\mathbf{x}$ & o & $\mathbf{x}$ & 0 \\
\hline \multicolumn{7}{|l|}{ Apricots } \\
\hline Derby... & $\ldots$ & $\ldots$ & $\ldots$ & $\ldots$ & o & o \\
\hline Royal............ & $\ldots$ & $\ldots$ & $\ldots$ & $\ldots$ & $\mathbf{x} \mathbf{x}$ & $\mathbf{x} \mathbf{x}$ \\
\hline Tilton............. & $\cdots$ & $\cdots$ & $\ldots$ & $\ldots$ & $\times \times 0$ & $\times \times 0$ \\
\hline \multicolumn{7}{|l|}{ BERRIES } \\
\hline Boysenberry..... & $\ldots$ & $\ldots$ & $\ldots$ & $\ldots$ & $\mathbf{x}$ & $\mathbf{x}$ \\
\hline Raspberry & & & & & & \\
\hline Black........... & $\ldots$ & $\ldots$ & $\ldots$ & $\ldots$ & $\mathbf{x}$ & 0 \\
\hline $\operatorname{Red} . \ldots \ldots \ldots \ldots \ldots \ldots \ldots$ & $\cdots$ & $\cdots$ & $\cdots$ & $\cdots$ & $\mathbf{0}$ & 0 \\
\hline Strawberry $\ldots \ldots \ldots \ldots \ldots \ldots \ldots$ & $\cdots$ & $\cdots$ & $\cdots$ & $\ldots$ & 0 & $\ldots$ \\
\hline Youngberry $\ldots \ldots \ldots \ldots \ldots \ldots$ & $\cdots$ & $\cdots$ & $\cdots$ & $\cdots$ & $\mathbf{x}$ & $\mathbf{x}$ \\
\hline \multicolumn{7}{|l|}{ Cherries } \\
\hline Bing.$\ldots \ldots \ldots \ldots \ldots \ldots \ldots \ldots \ldots$ & $\ldots$ & $\cdots$ & $\cdots$ & $\cdots$ & $\mathbf{x} \mathbf{x}$ & $\mathbf{x} \mathbf{x}$ \\
\hline Black Tartarian................ & $\ldots$ & $\ldots$ & $\ldots$ & $\ldots$ & $\mathbf{x} \mathbf{x}$ & $\mathbf{x} \mathbf{x}$ \\
\hline 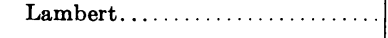 & $\cdots$ & $\cdots$ & $\cdots$ & $\cdots$ & $\mathbf{x}$ & $\mathbf{x}$ \\
\hline \multicolumn{7}{|l|}{ Frgs } \\
\hline Black Mission. . & $\ldots$ & ... & $\ldots$ & $\ldots$ & 0 & $\mathbf{0}$ \\
\hline Kadota $\ldots \ldots \ldots \ldots \ldots \ldots \ldots$ & $\mathbf{x}$ & $\mathbf{x}$ & $\mathbf{x}$ & $\mathbf{x}$ & o & $\mathbf{0}$ \\
\hline \multicolumn{7}{|l|}{ Grapes } \\
\hline Emperor....... & $\mathbf{x}$ & $\mathbf{x}$ & $\mathbf{x}$ & $\mathbf{x}$ & $\ldots$ & $\ldots$ \\
\hline Red Malaga..... & $\mathbf{x}$ & $\mathbf{x}$ & $\cdots$ & $\ldots$ & $\mathbf{x} \mathbf{x}$ & o \\
\hline 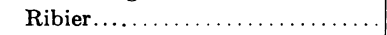 & $\ldots$ & $\ldots$ & $\ldots$ & $\ldots$ & $\mathrm{x}$ & 0 \\
\hline Thompson Seedless............ & $\mathbf{x}$ & $\mathbf{x}$ & $\mathbf{x}$ & $\mathbf{x}$ & $\mathbf{x} \times \mathbf{x}$ & x 00 \\
\hline Tokay................. & $\mathrm{x} \times$ & $\mathbf{x} \mathbf{x}$ & $\mathbf{x}$ & $\mathbf{x}$ & $\mathbf{x} \times$ & $\mathbf{x} \mathbf{x}$ \\
\hline White Malaga. . & $\mathbf{x}$ & $\mathbf{x}$ & $\cdots$ & $\cdots$ & $\cdots$ & $\cdots$ \\
\hline \multicolumn{7}{|l|}{ NECTARINES } \\
\hline Quetta..................... & $\cdots$ & $\cdots$ & $\cdots$ & $\cdots$ & $\mathbf{x}$ & $\mathbf{x}$ \\
\hline 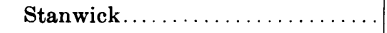 & $\ldots$ & $\ldots$ & $\ldots$ & $\ldots$ & $\mathbf{x}$ & $\mathbf{x}$ \\
\hline 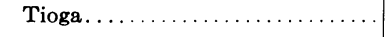 & $\cdots$ & $\cdots$ & $\cdots$ & $\cdots$ & $\mathbf{x}$ & 0 \\
\hline
\end{tabular}

$\mathrm{X}=$ Tolerant to treatment.

$\mathbf{0}=$ Not tolerant to treatment.

use of methyl bromide at a concentration of 2 pounds, 4 hours unless no better alternative is available.

Methyl Iodide. Methyl iodide was among the chemicals of greatest insecticidal value as indicated by $\mathrm{LD}_{9,5}$ data for naked eggs and larvae of the Oriental fruit fly. On the basis of these data, methyl iodide seems to be about four times as toxic to the Oriental fruit fly as is methyl bromide. Unfor- 
TABLE 11-Continued

\begin{tabular}{|c|c|c|c|c|c|c|}
\hline \multirow{2}{*}{ Commodity } & \multicolumn{4}{|c|}{1950} & \multicolumn{2}{|c|}{1951} \\
\hline & $1 \mathrm{lb}, 2 \mathrm{hrs}$ & $1 \mathrm{lb}, 4 \mathrm{hrs}$ & $2 \mathrm{lbs}, 2 \mathrm{hrs}$ & $2 \mathrm{lbs}, 4 \mathrm{hrs}$ & $2 \mathrm{lbs}, 2 \mathrm{hrs}$ & $2 \mathrm{lbs}, 4 \mathrm{hrs}$ \\
\hline \multicolumn{7}{|l|}{ Peaches } \\
\hline Blood Cling. & $\mathrm{x}$ & $\ldots$ & $\ldots$ & $\mathbf{x}$ & & .. \\
\hline Elberta...... & $\ldots$ & $\ldots$ & $\ldots$ & $\ldots$ & $\mathrm{x}$ & $\mathrm{x}$ \\
\hline Fay Elberta.. & $\ldots$ & $\ldots$ & $\ldots$ & $\ldots$ & $\mathrm{xx}$ & Xo \\
\hline Halehaven.. & $\ldots$ & $\ldots$ & $\ldots$ & $\ldots$ & $\mathrm{x}$ & $\mathrm{x}$ \\
\hline J. H. Hale. . & $\ldots$ & $\ldots$ & $\ldots$ & $\ldots$ & $\mathrm{x}$ & $\mathrm{x}$ \\
\hline July Elberta. & $\ldots$ & & & & $\mathrm{x}$ & $\mathrm{x}$ \\
\hline Kirkman...... & $\mathbf{x}$ & $\mathbf{x}$ & $\mathbf{x}$ & $\mathbf{x}$ & $\ldots$ & ... \\
\hline Palora........ & $\ldots$ & $\ldots$ & $\ldots$ & $\ldots$ & $\mathrm{x}$ & \\
\hline Rio Oso Gem. & $\ldots$ & $\ldots$ & $\ldots$ & $\ldots$ & $\mathrm{x}$ & $\mathrm{x}$ \\
\hline Sunbeam..... & $\ldots$ & $\ldots$ & $\ldots$ & $\ldots$ & $\mathbf{x}$ & $\mathbf{x}$ \\
\hline \multicolumn{7}{|l|}{ Pearg } \\
\hline Bartlett. & $\ldots$ & .. & & $\ldots$ & $\mathbf{x} \times \times x$ & $x \times 00$ \\
\hline Bosc..... & $\mathrm{x}$ & $\mathrm{x}$ & $\mathrm{x}$ & 0 & & $\mathrm{x}$ \\
\hline Comice...... & $\ldots$ & $\ldots$ & $\ldots$ & $\ldots$ & $\mathrm{x}$ & $\mathrm{x}$ \\
\hline Hardy.. & $\ldots$ & $\ldots$ & & $\ldots$ & $\mathrm{x}$ & $\mathrm{x}$ \\
\hline Winter Nelis. & $\mathrm{x}$ & $\ldots$ & $\mathrm{x}$ & $\ldots$ & $\mathrm{x}$ & $\mathbf{x}$ \\
\hline \multicolumn{7}{|l|}{ Pergimmons } \\
\hline Fuyu...... & 0 & 0 & 0 & 0 & $\ldots$ & .. \\
\hline Hachiya.. & $\mathbf{x}$ & $\mathrm{x}$ & $\mathrm{x}$ & o & $\ldots$ & \\
\hline Honan Red. & & & & & o & o \\
\hline Jumbu.. & 0 & o & o & o & $\ldots$ & . \\
\hline \multicolumn{7}{|l|}{ Plums } \\
\hline Beauty. & $\ldots$ & $\ldots$ & $\ldots$ & $\ldots$ & $\mathrm{xx}$ & oo \\
\hline Becky Smith. & $\ldots$ & $\ldots$ & $\ldots$ & $\ldots$ & 0 & o \\
\hline Burbank..... & $\ldots$ & $\ldots$ & $\ldots$ & $\ldots$ & $\mathbf{x}$ & o \\
\hline Climax... & $\ldots$ & $\ldots$ & $\ldots$ & $\ldots$ & $\mathrm{xx}$ & 00 \\
\hline Diamond. . & $\ldots$ & $\ldots$ & $\ldots$ & $\ldots$ & $\mathrm{x}$ & $\mathbf{x}$ \\
\hline Duarte..... & $\ldots$ & $\ldots$ & $\ldots$ & $\ldots$ & $\mathrm{x} x$ & Xo \\
\hline Earliana... & $\ldots$ & $\ldots$ & $\ldots$ & $\ldots$ & $\mathrm{x}$ & $\mathrm{x}$ \\
\hline Formosa........ & $\ldots$ & $\ldots$ & $\ldots$ & $\ldots$ & $\mathrm{x}$ & $\mathrm{x}$ \\
\hline Gaviota... & $\ldots$ & $\ldots$ & $\ldots$ & $\ldots$ & $\mathrm{x}$ & 0 \\
\hline Giant... & $\ldots$ & $\ldots$ & $\ldots$ & $\ldots$ & $\mathrm{x}$ & $\mathrm{x}$ \\
\hline Grand Duke.. & $\ldots$ & $\ldots$ & $\ldots$ & $\ldots$ & $\mathrm{x}$ & $\mathrm{x}$ \\
\hline Kelsey. & $\ldots$ & $\ldots$ & & & $\mathrm{x}$ & o \\
\hline President.. & $\mathrm{x}$ & $\mathrm{x}$ & $\mathrm{x}$ & $\mathrm{x}$ & & \\
\hline Santa Rosa. & $\ldots$ & $\ldots$ & $\ldots$ & $\ldots$ & $\mathrm{XX}$ & $x x$ \\
\hline Tragedy.... & $\ldots$ & $\ldots$ & $\ldots$ & $\ldots$ & $\mathrm{x}$ & $\mathbf{x}$ \\
\hline Wickson.... & $\ldots$ & $\ldots$ & $\ldots$ & $\ldots$ & $\mathrm{x} \times \mathrm{x}$ & $\mathrm{x} \times \mathrm{x}$ \\
\hline
\end{tabular}

$\mathrm{X}=$ Tolerant to treatment.

$\mathbf{O}=$ Not tolerant to treatment.

tunately this fumigant is highly corrosive to iron, which in itself might be sufficient reason to eliminate it from consideration. And even at very low concentrations it is irritating to persons working with it. Because of the corrosion problem, most of the tests were confined to 5-gallon glass containers. The data are presented in table 11.

The most obvious influence of methyl iodide was in retarding the ripening rate of fruits. This influence was noted on all fruit species where visible color or softening changes are important during ripening, and was closely related to concentration and exposure time. In most cases the delay in ripening re- 
sulting from dosages up to 2 pounds, 2 hours was not more than 3 days; this was not considered to indicate intolerance unless accompanied by some other in.jury symptom.

Among fruit lots damaged by methyl iodide the most frequent symptom was surface browning or scald. Sometimes this was accompanied by discoloration of the flesh. Off-flavor was recorded on several of the fruit lots with visible injury, but never by itself or where delay in ripening was the only effect noted. In fact, methyl iodide had less flavor effects, both immediately after treatment and later, than any other fumigant used in these tests.

Except for persimmons, all fruit varieties tested seemed tolerant to a dosage of 1 pound for 2 hours. Most fruits, except apples and persimmons, seemed tolerant to dosages of 1 pound, 4 hours and 2 pounds, 2 hours. Although the table shows almost complete similarity in results from these 2 dosages, detailed observations on color and firmness changes indicated that a dosage of 2 pounds for 2 hours usually had a greater physiological effect in delaying ripening than did a dosage of 1 pound for 4 hours. Apples seemed more tolerant to the dosage of 2 pounds for 2 hours in 1951 than in 1950 . It is not certain what brought about these differences, but seasonal variations may have contributed. Treatment of 2 pounds, 4 hours resulted in serious injury to a number of fruits, the most serious on apples and plums although quite a few fruits still seemed tolerant or were tolerant in part of the test. Persimmons, except the Hachiya variety, were intolerent even to treatment of 1 pound for 2 hours. This is in agreement with results secured with nearly all fumigants, where even the lowest dosage resulted in failure of the outer flesh of the fruit to soften normally.

The above data would indicate that methyl iodide can be used safely as a fumigant for most fruits at a dosage of 1 pound, 2 hours. Certain fruits may be tolerant to more severe treatments, but general use at higher levels would not be safe. The problems of handling and the corrosive nature and present high cost of methyl iodide make it doubtful that the chemical will establish itself as a fresh-fruit fumigant.

Fthylene Chlorobromide. Ethylene chlorobromide (ECB) was reported to be one of the most toxic fumigants found in screening tests made with naked eggs and larvae of the Oriental fruit fly. Preliminary studies of fruit tolerance to ECB, in 1950 , involved a dosage range that included concentrations of 1, 2, and 4 pounds for 2 and 4 hours, with 5 -gallon glass jars used as treatment chambers.

Highly promising preliminary results indicated the desirability of conducting more critical tests in 1951, most of which were carried out in a walk-in type of fumigation chamber.

ECB, having a high boiling point, requires special procedures to assure complete and rapid vaporization. Both heating and atomizing in turbulent air were successful, as indicated by chemical analyses of the fumigant concentration in the chamber.

Table 12 summarizes the fruit tolerance results secured both in 1950 and 1951. 
Immediately following fumigation with ECB an off-flavor was always found in fruits. The degree of off-flavor was somewhat proportionate to the fumigant concentration and the exposure time. It usually disappeared completely after 1 to 8 days, the rate of disappearance depending primarily upon temperature and the original treatment dosage. Off-flavor was detectable much longer if fruit was held in cold storage instead of at somewhat higher temperatures. In nearly all cases the off-flavor disappeared during the simulated transit period and was not detectable after that. Furthermore the natural aroma of the fruit was not damaged, unlike the case with methyl bromide and some other chemicals. Where off-flavor disappeared during the simulated transit period and no influence on natural aroma or appearance was detected the fruit was considered tolerant to the treatment.

ECB at the dosages used had little effect on subsequent rates of ripening. Observations on a few fruits indicated a slight retardation of ripening, but in most cases ripening of treated lots was identical with the controls. Certainly any influence of $\mathrm{ECB}$ on ripening is minor compared with that of most of the chemicals tested.

The injury recorded on Jonathan apples in 1950 was a surface spotting, evident only after the fruit had been held at $68^{\circ} \mathrm{F}$ for 13 days, which might have offered no problem on the market. It was not found on the lot given a dosage of 2 pounds for 4 hours the following year. The only lot of strawberries given this dosage in 1951 failed to recover normal flavor, but there was no visible evidence of injury. In 1950 the appearance of Blood Cling peaches was not affected, but the flavor was permanently damaged, by a dosage of 4 pounds, 4 hours; neither was affected by a dosage of 2 pounds, 2 hours. Palora peaches treated at the rate of 2 pounds for 4 hours in 1951 did not develop acceptable eating quality, but lower dosages were not damaging. With the exception of Hachiya in 1951, all varieties of persimmons were injured in both years at all treatment levels at a dosage of 1 pound, 2 hours. Injury was in the form of abnormal ripening, evidenced by a thick, leathery outer layer of flesh. Of the 16 varieties of plums included in the study only 1 lot of Wickson, given a dosage of 2 pounds for 2 hours in 1951, developed an objectionable flavor during the marketing period. This lot of fruit was recorded as having normal flavor after a 10-day simulated transit period, which would prompt one to believe that the subsequently developed off-flavor was not caused by retention of the fumigant.

On the basis of these data all fruits except the persimmon were tolerant to a dosage of 1 pound for 2 hours. In fact, except for 1 lot of Wickson plums, not only were other fruits tolerant to a dosage of 2 pounds for 2 hours, but nearly all fruits appeared tolerant even to a dosage of 2 pounds for 4 hours. When ECB and methyl bromide are compared with respect to fruit tolerances and the $\mathrm{LD}_{95}$ data in table $1, \mathrm{ECB}$ appears to have a great advantage. Should studies with insects continue to show low requirements for lethal dosage, ECB would have several times the margin of safety of methyl bromide.

In these studies the fruit may have been exposed to somewhat more severe treatments than would be indicated by the calculated space dosages. ECB is fairly soluble in water. If only a small volume of fruit is treated with ECB in a fairly large chamber, there is a likelihood that the fumigant sorbed by 
TABLE 12

TOLERANCE OF VARIOUS FRUITS TO ETHYLENE CHLOROBROMIDE FUMIGATION

\begin{tabular}{|c|c|c|c|c|c|c|c|c|c|}
\hline \multirow{2}{*}{ Commodity } & \multicolumn{6}{|c|}{1950} & \multicolumn{3}{|c|}{1951} \\
\hline & $\begin{array}{l}1 \mathrm{lb}, \\
2 \mathrm{hrs}\end{array}$ & $\begin{array}{l}1 \mathrm{lb}, \\
4 \mathrm{hrs}\end{array}$ & $\begin{array}{l}2 \mathrm{lbs}, \\
2 \mathrm{hrs}\end{array}$ & $\begin{array}{l}2 \mathrm{lbs}, \\
4 \mathrm{hrs}\end{array}$ & $\begin{array}{l}4 \mathrm{lbs}, \\
2 \mathrm{hrs}\end{array}$ & $\begin{array}{l}4 \mathrm{lbs} \\
4 \mathrm{hrs}\end{array}$ & $\begin{array}{l}1 \mathrm{lb}, \\
2 \mathrm{hrs}\end{array}$ & $\begin{array}{l}2 \mathrm{lbs}, \\
2 \mathrm{hrs}\end{array}$ & $\begin{array}{l}2 \mathrm{lbs}, \\
4 \mathrm{hrs}\end{array}$ \\
\hline \multicolumn{10}{|l|}{ Apples } \\
\hline Bellflower. & . & . & .. & . & .. & . & $\mathbf{X}^{*}$ & $\mathrm{X}^{*}$ & $\mathbf{X}^{*}$ \\
\hline Golden Delicious.............. & .. & . & $\mathbf{x}$ & $\mathbf{x}$ & $\mathbf{x}$ & $\mathbf{x}$ & $\mathrm{x}^{*} \mathrm{X}^{*}$ & $\mathrm{X}^{*} \mathrm{X}^{*}$ & $\mathrm{X}^{*} \mathrm{X}^{*}$ \\
\hline Gravenstein $\ldots \ldots \ldots \ldots \ldots \ldots$ & $\mathbf{x} \mathbf{x}$ & $\mathbf{x} \mathbf{x}$ & $\mathbf{x}$ & $\mathbf{x}$ & . & . & $\mathbf{X}^{*} \mathbf{X}^{*}$ & $\mathrm{X}^{*} \mathrm{X}^{*}$ & $\mathrm{X}^{*} \mathrm{X}^{*}$ \\
\hline 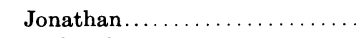 & $\ldots$ & $\ldots$ & $\mathrm{x}$ & 0 & $\mathbf{0}$ & 0 & $\mathbf{X}^{*}$ & $\mathrm{X}^{*}$ & $\mathrm{X}^{*}$ \\
\hline Red Delicious............ & . & . & $\mathbf{x}$ & $\mathbf{x}$ & $\mathbf{x}$ & $\mathbf{x}$ & $\mathrm{X}^{*} \mathrm{X}^{*} \mathrm{X}^{*}$ & $\mathrm{X}^{*} \mathrm{X}^{*} \mathrm{X}^{*}$ & $\mathrm{X}^{*} \mathrm{X}^{*} \mathrm{X}^{*}$ \\
\hline Rome Beauty . . . . . . . . . . & .. & . & $\mathbf{x}$ & $\mathbf{x}$ & $\mathbf{x}$ & $\mathbf{x}$ & $\mathbf{X}^{*}$ & $\mathrm{X}^{*}$ & $\mathrm{X}^{*}$ \\
\hline Winesap $\ldots \ldots \ldots \ldots \ldots \ldots \ldots$ & .. & .. & . & . & . & .. & $\mathbf{X}^{*}$ & $\mathrm{X}^{*}$ & $\mathbf{X}^{*}$ \\
\hline Yellow Newtown.............. & . & . & $\mathbf{x}$ & $\mathbf{x}$ & $\mathbf{x}$ & $\mathbf{x}$ & $\mathrm{X}^{*} \mathrm{X}^{*}$ & $\mathrm{X}^{*} \mathrm{X}^{*}$ & $\mathrm{X}^{*} \mathrm{X}^{*}$ \\
\hline \multicolumn{10}{|l|}{ Apricots } \\
\hline Derby.. & . & . & .. & . & . & . & $\mathbf{x}$ & $\mathbf{x}$ & ... \\
\hline Royal... & . & . & . & . & . & . & $\mathbf{x} \times$ & $\mathbf{x} \mathbf{x}$ & $\ldots$ \\
\hline Tilton............. & .. & .. & .. & . & . & .. & $\mathbf{x} \times \mathbf{x}$ & $\mathbf{x} \times \mathbf{x}$ & $\cdots$ \\
\hline \multicolumn{10}{|l|}{ Berries } \\
\hline Boysenberry... & . & . & . & $\cdots$ & . & . & $\mathbf{x}$ & $\mathbf{x}$ & $\ldots$ \\
\hline Raspberry & & & & & & & & & \\
\hline Black... & . & . & . & . & . & . & $\mathbf{x}$ & $\mathbf{x}$ & $\ldots$ \\
\hline $\operatorname{Red} \ldots \ldots \ldots \ldots \ldots \ldots$ & . & . & . & . & . & . & $\mathbf{x}$ & $\mathbf{x}$ & $\ldots$ \\
\hline Strawberry .................. & .. & . & .. & .. & . & .. & $\mathrm{X}^{*}$ & $\mathrm{X}^{*}$ & $0^{*}$ \\
\hline Youngberry................. & .. & . & . & . & . & . & $\mathbf{x}$ & $\mathbf{x}$ & $\ldots$ \\
\hline \multicolumn{10}{|l|}{ Cherries } \\
\hline Bing.... & .. & . & . & .. & . & . & $\mathbf{x} \mathbf{x}$ & $\mathbf{x} x$ & $\ldots$ \\
\hline Black Tartarian.... & . & . & .. & . & . & . & $\mathbf{x} \mathbf{x}$ & $\mathbf{x} \mathbf{x}$ & $\ldots$ \\
\hline Lambert................ & . & . & . & .. & . & .. & $\mathbf{x}$ & $\mathbf{x}$ & $\cdots$ \\
\hline \multicolumn{10}{|l|}{ Figs } \\
\hline Black Mission. & . & . & .. & . & . & . & $\mathrm{X}^{*}$ & $\mathrm{X}^{*}$ & $\mathbf{X}^{*}$ \\
\hline Kadota............. & .. & . & .. & . & . & .. & $\mathrm{X}^{*}$ & $\mathrm{X}^{*}$ & $\mathrm{X}^{*}$ \\
\hline \multicolumn{10}{|l|}{ Grapes } \\
\hline Emperor.... & . & . & . & 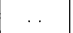 & . & & $\mathrm{X}^{*}$ & $\mathbf{X}^{*}$ & $\mathbf{X}^{*}$ \\
\hline Red Malaga... & . & . & $\mathbf{x}$ & $\mathbf{X}$ & $\mathrm{x}$ & $\mathrm{x}$ & $\mathrm{X}^{*} \mathrm{X}^{*}$ & $\mathrm{X}^{*} \mathrm{X}^{*}$ & $\mathrm{X}^{*}$ \\
\hline Ribier......... & . & . & . & . & . & . & $\mathrm{X}^{*}$ & $\mathrm{X}^{*}$ & $\mathbf{X}^{*}$ \\
\hline Thompson Seedless....... & $\mathbf{x}$ & 0 & $\mathrm{ox}$ & $\mathrm{ox}$ & .. & . & $\mathrm{X}^{*} \mathrm{X}^{*} \mathrm{X}^{*}$ & $\mathrm{X}^{*} \mathrm{X}^{*} \mathrm{X}^{*}$ & $\mathrm{X}^{*} \mathrm{X}^{*} \mathrm{X}^{*}$ \\
\hline Tokay..................... & . & . & $\mathbf{x}$ & $\mathrm{x}$ & $\mathbf{x}$ & $\mathbf{x}$ & $\mathbf{X}^{*} \mathbf{X}^{*}$ & $\mathbf{X}^{*} \mathbf{X}^{*}$ & $\mathbf{X}^{*} \mathbf{X}^{*}$ \\
\hline White Malaga ................ & . & . & $\mathbf{x}$ & $\mathbf{x}$ & $\mathbf{x}$ & $\mathbf{x}$ & $\mathrm{X}^{*}$ & $x^{*}$ & $\mathrm{X}^{*}$ \\
\hline \multicolumn{10}{|l|}{ Nectarines } \\
\hline Dargaville.... & . & . & .. & . & . & . & $\mathbf{x}$ & $\mathbf{x}$ & $\ldots$ \\
\hline Gower..................... & . & . & . & . & .. & . & $\mathbf{x}$ & $\mathbf{x}$ & $\ldots$ \\
\hline Quetta................... & . & .. & .. & . & .. & .. & $\mathbf{x}$ & $\mathbf{x}$ & $\ldots$ \\
\hline Stanwick................. & $\mathbf{x}$ & .. & .. & $\mathrm{x}$ & .. & .. & $\mathrm{X}^{*}$ & $\mathbf{X}^{*}$ & $\mathrm{x}^{*}$ \\
\hline Tioga $\ldots \ldots \ldots \ldots \ldots \ldots \ldots$ & .. & . & .. & .. & .. & . & $\mathrm{X}^{*}$ & $\mathbf{X}^{*}$ & $\mathbf{x}^{*}$ \\
\hline
\end{tabular}

* In 1950, all treatments were in 5-gallon glass containers. In 1951, most treatments were in a 252-cubic-foot fumigation chamber and are marked with an asterisk; the remainder were in the 5-gallon containers.

$\left.\begin{array}{l}\mathrm{X}=\text { Tolerant to treatment } \\ \mathrm{O}=\text { Not tolerant to treatment }\end{array}\right\}$ Repetition indicates additional tests. 
TABLE 12-Continued

\begin{tabular}{|c|c|c|c|c|c|c|c|c|c|}
\hline \multirow{2}{*}{ Commodity } & \multicolumn{6}{|c|}{1950} & \multicolumn{3}{|c|}{1951} \\
\hline & $\begin{array}{l}1 \mathrm{lb}, \\
2 \mathrm{hrs}\end{array}$ & $\begin{array}{l}1 \mathrm{lb}, \\
4 \mathrm{hrs}\end{array}$ & $\begin{array}{l}2 \mathrm{lbs}, \\
2 \mathrm{hrs}\end{array}$ & $\begin{array}{l}2 \mathrm{lbs}, \\
4 \mathrm{hrs}\end{array}$ & $\begin{array}{l}4 \mathrm{lbs} \\
2 \mathrm{hrs}\end{array}$ & $\begin{array}{l}4 \mathrm{lbs}, \\
4 \mathrm{hrs}\end{array}$ & $\begin{array}{l}1 \mathrm{lb}, \\
2 \mathrm{hrs}\end{array}$ & $\begin{array}{l}2 \mathrm{lbs}, \\
2 \mathrm{hrs}\end{array}$ & $\begin{array}{l}2 \mathrm{lbs}, \\
4 \mathrm{hrs}\end{array}$ \\
\hline \multicolumn{10}{|l|}{ Peaches } \\
\hline Blood Cling. & . & . & $\mathbf{x}$ & . & . & o & $\ldots$ & $\ldots$ & $\ldots$ \\
\hline Elberta................. & . & . & . & . & . & . & $\mathbf{x}$ & $\mathbf{x}$ & $\ldots$ \\
\hline Fay Elberta.............. & . & .. & . & . & . & .. & $\mathrm{x} \times$ & $\mathbf{x} \mathbf{x}$ & $\ldots$ \\
\hline 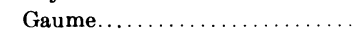 & $\mathbf{x}$ & .. & . & $\mathbf{x}$ & . & .. & $\ldots$ & $\ldots$ & $\ldots$ \\
\hline Halehaven.............. & . & . & . & . & $\cdots$ & . & $\mathrm{x}$ & $\mathrm{x}$ & $\cdots$ \\
\hline J. H. Hale . . . . . . . . . . . . & . & . & . & . & . & . & $\mathbf{x}$ & $\mathrm{x}$ & $\ldots$ \\
\hline July Elberta................ & .. & . & .. & . & . & . & $\mathbf{x}$ & $\mathbf{x}$ & $\ldots$ \\
\hline June Elberta................ & . & . & .. & .. & . & . & $\mathbf{x}$ & $\mathbf{x}$ & $\ldots$ \\
\hline Kirkman................ & . & . & $\mathbf{x}$ & $\mathbf{x}$ & $\mathbf{x}$ & $\mathbf{x}$ & $\ldots$ & ... & $\cdots$ \\
\hline Palora $\ldots \ldots \ldots \ldots \ldots \ldots$ & . & $\cdots$ & .. & . & . & . & $\mathrm{X}^{*}$ & $\mathrm{X}^{*}$ & $0^{*}$ \\
\hline Rio Oso Gem.............. & . & . & . & $\cdots$ & . & . & $\mathbf{x}$ & $\mathbf{x}$ & $\ldots$ \\
\hline Sunbeam................. & . & . & .. & .. & . & .. & $\mathrm{x} \times$ & $\mathbf{x} \mathbf{x}$ & $\ldots$ \\
\hline \multicolumn{10}{|l|}{ Pears } \\
\hline Bartlett. & $\mathbf{x} \times \mathbf{x}$ & $\mathbf{x} \mathbf{x}$ & $\mathrm{xx}$ & $\mathbf{x} \times \mathbf{x}$ & . & . & $\mathrm{X}^{*} \mathrm{X}^{*} \mathrm{X}^{*}$ & $\mathrm{X}^{*} \mathrm{X}^{*} \mathrm{X}^{*}$ & $\mathrm{X}^{*} \mathrm{X}^{*} \mathrm{X}^{*}$ \\
\hline Bosc..... & .. & . & $\mathbf{x}$ & $\mathbf{x}$ & $\mathbf{x}$ & $\mathbf{x}$ & $\mathrm{X}^{*}$ & $\mathrm{X}^{*}$ & $\mathrm{x}^{*}$ \\
\hline Comice.................. & . & . & .. & .. & . & .. & $\mathrm{X}^{*}$ & $\mathrm{X}^{*}$ & $\mathrm{X}^{*}$ \\
\hline Hardy .................... & . & . & . & . & . & . & $\mathrm{X}^{*}$ & $\mathrm{X}^{*}$ & $\mathbf{X}^{*}$ \\
\hline Winter Nelis.............. & . & .. & . & . & . & .. & $\mathrm{X}^{*}$ & $\mathrm{X}^{*}$ & $\mathrm{X}^{*}$ \\
\hline \multicolumn{10}{|l|}{ Persimmons } \\
\hline 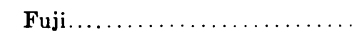 & . & . & .. & . & . & . & $0^{*}$ & $\mathrm{O}^{*}$ & $0^{*}$ \\
\hline 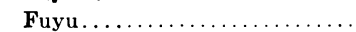 & . & . & 0 & o & 0 & $\mathbf{0}$ & $\ldots$ & $\ldots$. & $\ldots$ \\
\hline 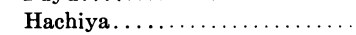 & . & . & $\mathbf{0}$ & o & o & o & $\mathrm{X}^{*}$ & $0^{*}$ & $\mathrm{O}^{*}$ \\
\hline Honan Red.................. & . & . & . & . & . & . & $0^{*}$ & $0^{*}$ & $0^{*}$ \\
\hline Jumbu $\ldots \ldots \ldots \ldots \ldots \ldots$ & . & . & o & 0 & o & o & $\ldots$ & $\ldots$ & $\ldots$ \\
\hline Nishirazu................. & . & .. & .. & . & . & . & $\mathrm{O}^{*}$ & $\mathrm{O}^{*}$ & $\mathrm{O}^{*}$ \\
\hline \multicolumn{10}{|l|}{ Plums } \\
\hline Beauty......... & . & . & .. & . & $\cdots$ & .. & $\mathrm{x} \mathrm{x}$ & $\mathbf{x} \mathbf{x}$ & $\ldots$ \\
\hline Becky Smith............... & . & .. & . & .. & . & .. & $\mathbf{x}$ & $\mathbf{x}$ & $\cdots$ \\
\hline Burbank.................. & . & . & . & .. & . & .. & $\mathbf{x}$ & $\mathbf{x}$ & $\cdots$ \\
\hline 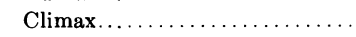 & . & . & .. & .. & . & . & $\mathrm{x} \mathrm{x}$ & $\mathbf{x} \mathbf{x}$ & $\cdots$ \\
\hline Diamond .................. & . & . & . & .. & . & .. & $\mathbf{x}$ & $\mathbf{x}$ & $\ldots$ \\
\hline 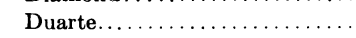 & . & . & . & .. & . & . & $\mathrm{X} \mathrm{X}^{*}$ & $\mathrm{X} \mathrm{X}^{*}$ & $\mathrm{X}^{*}$ \\
\hline Earliana ................ & . & . & . & .. & . & . & $\mathbf{x}$ & $\mathbf{x}$ & $\ldots$ \\
\hline Formosa $\ldots \ldots \ldots \ldots \ldots$ & . & . & . & . & . & . & $\mathbf{x}$ & $\mathbf{x}$ & $\ldots$ \\
\hline Gaviota .................. & . & . & . & . & . & . & $\mathbf{x}$ & $\mathbf{x}$ & $\ldots$ \\
\hline Giant........... & $\mathbf{x}$ & $\mathbf{x}$ & $\mathbf{x}$ & $\mathbf{x}$ & . & .. & $\mathbf{X}^{*}$ & $\mathrm{X}^{*}$ & $\mathrm{X}^{*}$ \\
\hline Grand Duke............. & . & . & . & . & . & . & $\mathbf{X}^{*}$ & $\mathrm{X}^{*}$ & $\mathbf{X}^{*}$ \\
\hline Kelsey $\ldots \ldots \ldots \ldots \ldots \ldots \ldots$ & . & . & . & .. & $\ldots$ & . & $\mathrm{X}^{*}$ & $\mathrm{X}^{*}$ & $\mathrm{X}^{*}$ \\
\hline President. . . . . . . . . . . . . & . & . & $\mathrm{x}$ & $\mathbf{x}$ & $\mathrm{x}$ & $\mathbf{x}$ & $\mathrm{X}^{*}$ & $\mathrm{X}^{*}$ & $\mathrm{X}^{*}$ \\
\hline Santa Rosa................. & . & . & .. & .. & .. & . & $\mathbf{x} \mathbf{x}$ & $\mathbf{x ~ x}$ & $\ldots$ \\
\hline Tragedy $\ldots \ldots \ldots \ldots \ldots \ldots$ & . & . & . & . & . & . & $\mathrm{x}$ & $\mathrm{x}$ & $\ldots$ \\
\hline Wickson $\ldots \ldots \ldots \ldots \ldots \ldots$ & . & . & . & .. & . & . & $\mathbf{x} \mathbf{x}$ & x o & $\ldots$ \\
\hline
\end{tabular}

* In 1950, all treatments were in 5-gallon glass containers. In 1951, most treatments were in a 252-cubic-foot fumigation chamber and are marked with an asterisk; the remainder were in the 5-gallon containers. $\left.\begin{array}{l}\mathrm{X}=\text { Tolerant to treatment } \\ \mathrm{O}=\text { Not tolerant to treatment }\end{array}\right\}$ Repetition indicates additional tests. 
the fruit may be somewhat greater than would be the case if the chamber were fairly well filled with fruit. Trials in 1952 indicated this to be true. Taste tests showed that off-flavor became less detectable as the chamber load was increased. These observations were also verified chemically. On this basis the tolerance data shown in the table are in reality lower than might be expected under conditions of commercial treatment.

Fthylene Dibromide. Screening tests in Hawaii showed ethylene dibromide (EDB) to have outstanding insecticidal qualities against naked eggs and larvae of the Oriental fruit fly. As soon as this information was made available in detail, preliminary tolerance tests with California deciduous fruits were begun. In 1950, concentrations of $1 / 2,1,2$, and 4 pounds per 1,000 cubic feet of space for exposure periods of 2 and 4 hours were selected for preliminary trials. The early treatments were made in 5-gallon jars. When the 252-cubic-foot fumigation room was completed in midseason, many of the tests were run in it. The encouraging results, especially at lower dosages, indicated the desirability of a more detailed and critical study.

This was done in 1951, when all tests were conducted in the large fumigation chamber. The 4-pound dosages were dropped from the treatment program. All tests were made on lots of fruit that were small in relation to chamber size, usually less than a 5 per cent load.

EDB has a high boiling point and, like ethylene chlorobromide (ECB), requires special procedures to assure complete vaporization. Heating or atomizing in turbulent air were found to be effective means of vaporizing the chemical.

Table 13 summarizes the results.

All fruits treated with ethylene dibromide had an objectionable flavor after treatment. The off-flavor seemed to be due to the chemical residue, usually disappearing completely within 1 to 8 days, depending on temperature, size of fruit, fumigant concentration, and treatment time. It seemed to be greater when treatment was made in the large chamber than when made in 5-gallon glass jars. It was thought at first that this difference might be due to incomplete evaporation of the fumigant in the small container. Later, chemical studies indicated that volume of space in the fumigation chamber in relation to volume of fruit being tested is the important factor. This is discussed in detail in the section entitled "Chemical Studies." The chemical type of off-flavor was always transient and, unless it persisted into the marketing period, was not indicated as harmful when fruit tolerance was recorded. Where injury from high fumigant concentrations occurred to the fruit surface or flesh - such as scald, flesh browning, or internal breakdowna different type of off-flavor sometimes developed, permanent in effect and associated with the physiology of the fruit. Even when no injury to appearance was evident and the chemical flavor had disappeared, the aroma and flavor of some fruits seemed to be permanently damaged. A summary of the injury symptoms recorded on fruits in 1950 and 1951 is given in tables 14 and 15 .

The data show that all the fruits tested, except raspberries and persimmons, were tolerant to a dosage of $1 / 2$ pound, 2 hours. Raspberries have 


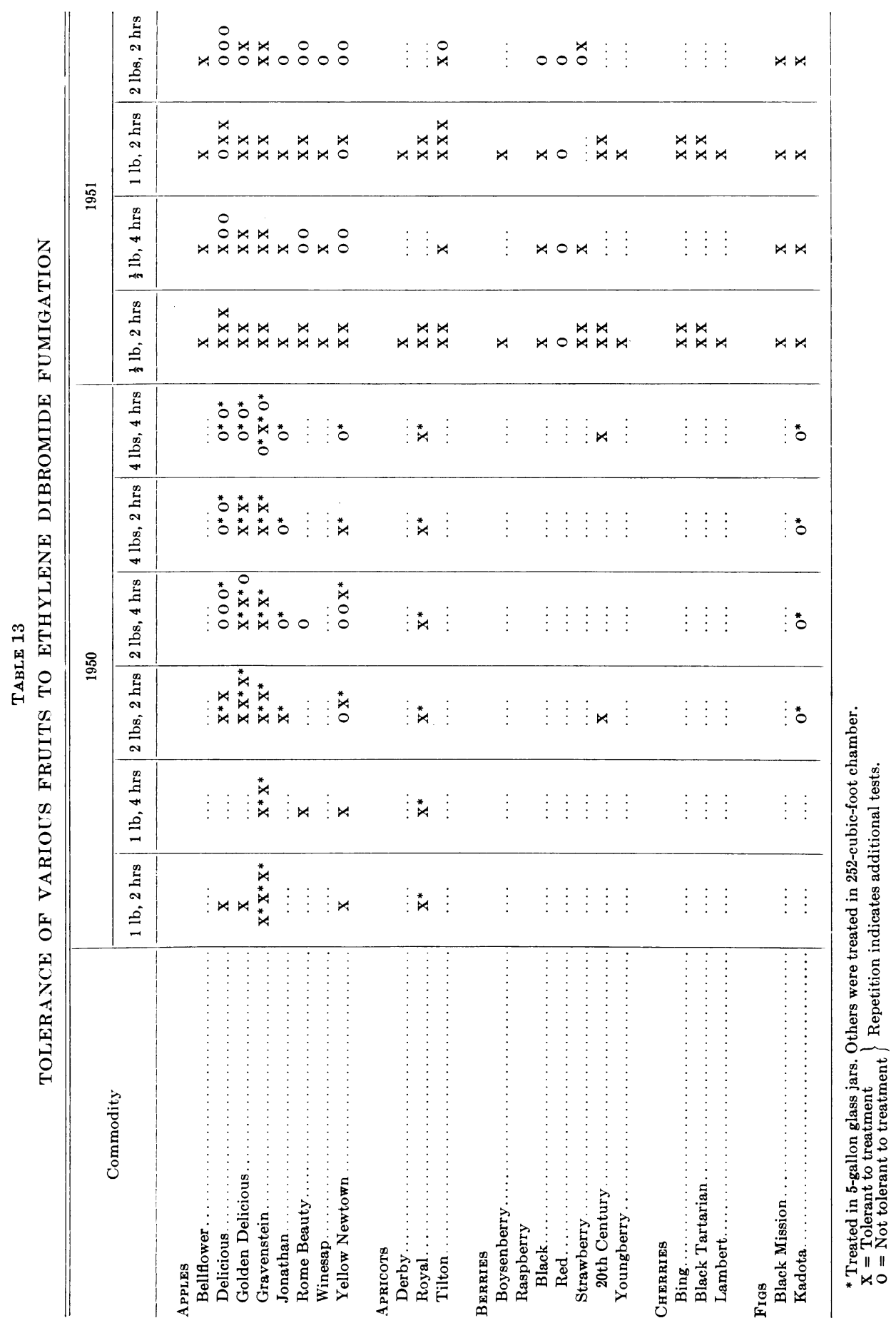




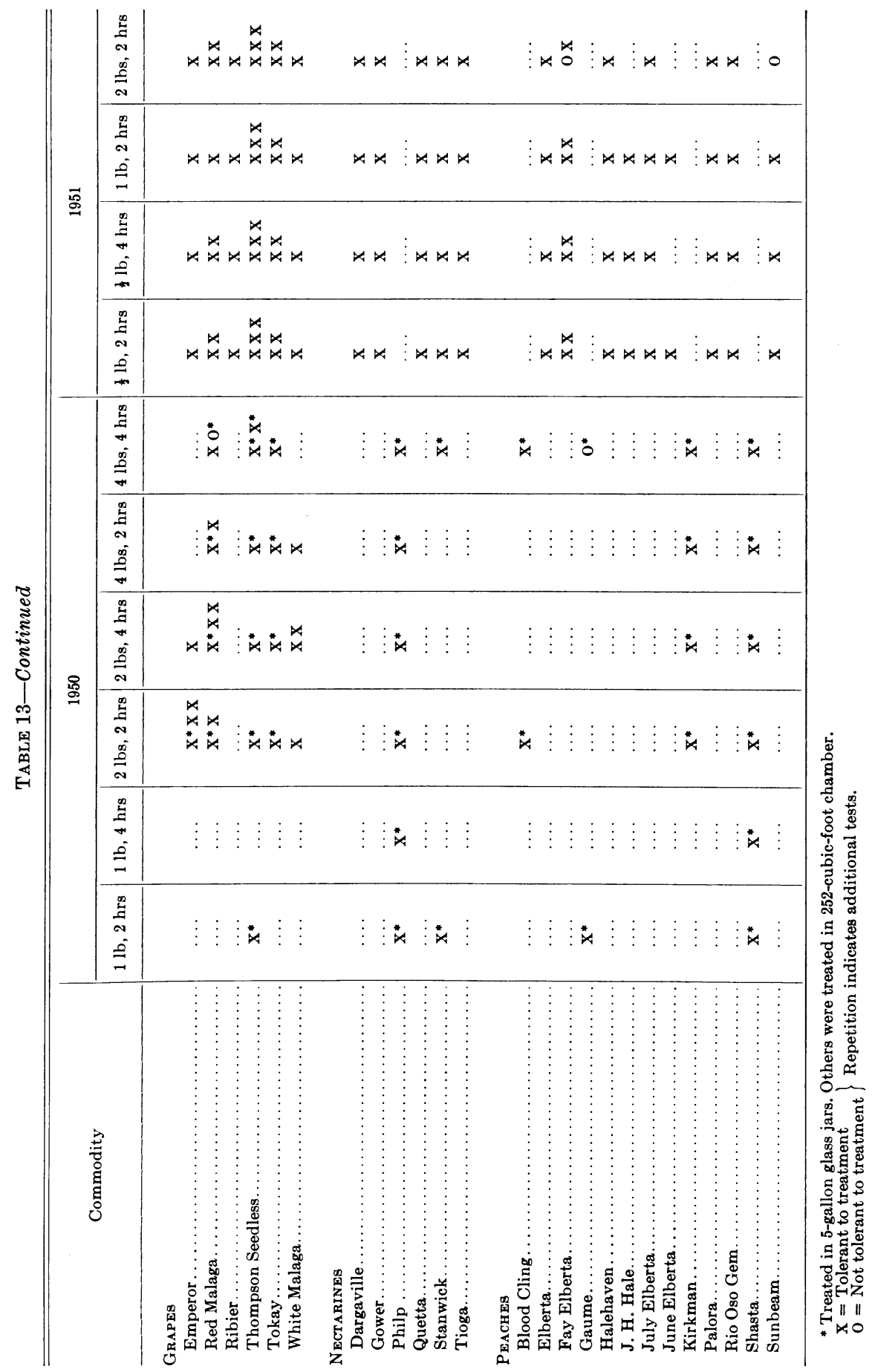




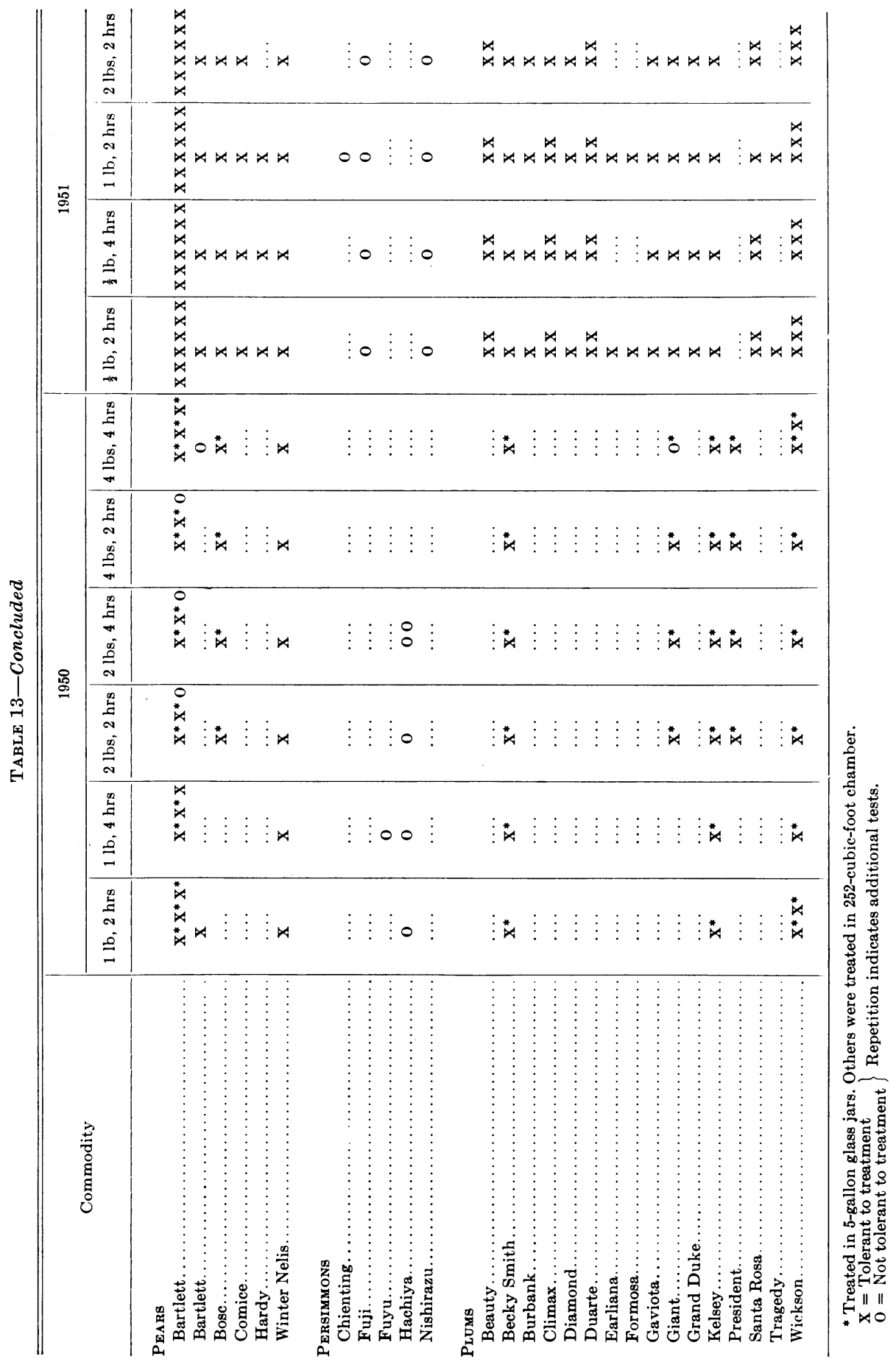


TABLE 14

INJURY SYMPTOMS OF FRUITS TREATED WITH ETHYLENE DIBROMIDE IN 1950

\begin{tabular}{|c|c|c|c|c|}
\hline Fruit & $\begin{array}{l}\text { Pounds } \\
\text { concen- } \\
\text { tration }\end{array}$ & $\begin{array}{l}\text { Hours } \\
\text { exposure }\end{array}$ & $\begin{array}{l}\text { Treat- } \\
\text { ment } \\
\text { space }\end{array}$ & Injury sy mptoms and remarks \\
\hline \multicolumn{5}{|l|}{ APPLE } \\
\hline Delicious........... & 2 & 4 & Jar & Light scald \\
\hline Delicious.......... & 4 & 2 & Jar & Moderate scald, slight off-flavor \\
\hline Delicious........... & 4 & 4 & Jar & Severe scald, off-flavor \\
\hline Delicious... & 2 & 4 & Chamber & Moderate scald \\
\hline Golden Delicious... & 2 & 4 & Chamber & Slight surface browning adjacent to lenticels \\
\hline Gravenstein... & 4 & 4 & Jar & Light scald 12 to 15 days after treatment \\
\hline Jonathan.... & 2 & 4 & Jar & Light scald 12 to 15 days after treatment \\
\hline Jonathan. & 4 & 2 & Jar & Moderate scald 12 to 15 days after treatment \\
\hline Jonathan. & 4 & 4 & Jar & Moderate scald 12 to 15 days after treatment \\
\hline Rome.... & 2 & 4 & Chamber & $\begin{array}{l}\text { Light scald, fruit cold-stored about } 6 \text { weeks hefore } \\
\text { treatment and } 20 \text { days at } 41^{\circ} \mathrm{F} \text { after treatment. Scald } \\
\text { evident } 1 \text { week later }\end{array}$ \\
\hline Yellow Newtown.. & 2 & 2 & Chamber & Light scald \\
\hline Yellow Newtown.. & 2 & 4 & Chamber & Moderate scald developed soon after removal to $68^{\circ} \mathbf{F}$ \\
\hline Yellow Newtown... & 4 & 4 & Jar & Scald and off-flavor \\
\hline \multicolumn{5}{|l|}{ Figs } \\
\hline Kadota.. & 2,4 & 2,4 & Jar & $\begin{array}{l}\text { Light surface browning. Commercial significance un- } \\
\text { certain }\end{array}$ \\
\hline \multicolumn{5}{|l|}{ Grapes } \\
\hline Red Malaga. & 4 & 4 & Jar & Musty flavor \\
\hline \multicolumn{5}{|l|}{ Peaches } \\
\hline Gaume. & 4 & 4 & Jar & Off-flavor, appearance normal \\
\hline \multicolumn{5}{|l|}{ Pears } \\
\hline Bartlett. & 2 & 2 & Chamber & $\begin{array}{l}\text { Flesh browning. Fruit stored } 41 \text { days at } 32^{\circ} \mathrm{F} \text { before } \\
\text { treatment }\end{array}$ \\
\hline Bartlett. & 2 & 4 & Chamber & $\begin{array}{l}\text { Severe flesh browning and surface necrotic areas } \\
\text { around lenticels. Fruit stored } 41 \text { days at } 32^{\circ} \mathrm{F} \text { before } \\
\text { treatment }\end{array}$ \\
\hline Bartlett. . & 4 & 4 & Chamber & $\begin{array}{l}\text { Core breakdown, severe flesh browning and scald; } \\
\text { off-flavor. Fruit stored } 41 \text { days at } 32^{\circ} \mathrm{F} \text { before treat- } \\
\text { ment }\end{array}$ \\
\hline \multicolumn{5}{|r|}{ Whe } \\
\hline Fuyu...... & $1 / 2$ & 2 & Chamber & All varieties failed to ripen properly after treatment in \\
\hline Fuyu...... & 1 & 4 & Chamber & dosage range used. Outer flesh remained firm and \\
\hline Hachiya........... & 1,2 & 2,4 & Chamber & somewhat leathery, although area near core softened \\
\hline Tamopan.......... & $1 / 2$ & 2 & Chamber & \\
\hline \multicolumn{5}{|l|}{ Plums } \\
\hline Giant. & 4 & 4 & Chamber & Scald \\
\hline
\end{tabular}

such a short holding and marketing period that some chemical flavor persisted during the marketing period, which was considered objectionable. It seems probable that the off-flavor would not have been found under commercial conditions, where a large volume of raspberries would be present in the fumigation chamber during treatment, but we have no data on this point. Persimmons, which were highly sensitive to other fumigants, were also affected by EDB, failing to soften normally following treatment. The quantities of these fruits produced in California and entering into interstate commerce are small. 
With the additional exception of some apple varieties all other fruits were tolerant to a dosage of 1 pound, 2 hours, and most fruits to a dosage of 2 pounds, 2 hours. One of the injuries recorded for apples was scald, which developed late in the marketing period and would probably be of little commercial significance. Since these tests were made with a 5 per cent load, or

TABLE 15

INJURY SYMPTOMS OF FRUITS TREATED WITH ETHYLENE DIBROMIDE IN 252-CUBIC-FOOT CHAMBER IN 1951

\begin{tabular}{|c|c|c|c|}
\hline Fruit & $\begin{array}{l}\text { Pounds } \\
\text { concen- } \\
\text { tration }\end{array}$ & $\begin{array}{c}\text { Hours } \\
\text { exposure }\end{array}$ & Injury symptoms and remarks \\
\hline \multicolumn{4}{|l|}{ APples } \\
\hline Delicious. . & $1 / 2$ & 4 & Light scald developed during marketing period \\
\hline & 1 & 2 & Light scald developed during marketing period \\
\hline & 2 & 2 & Scald, no off-flavor but loss of aroma \\
\hline Golden Delicious..... & 2 & 2 & Loss of natural aroma and development of light scald \\
\hline Jonathan............ & 2 & 2 & $\begin{array}{l}\text { Fruit stored until December 4, probably about } 70 \text { days before } \\
\text { treatment. Some surface blotchiness, flavor normal }\end{array}$ \\
\hline \multirow[t]{4}{*}{ Rome.. } & $1 / 2$ & 4 & Light scald $\quad 314$ days at $68^{\circ} \mathrm{F}$ before treatment \\
\hline & 2 & 2 & Scald and internal breakdown $\int^{14}$ days at oo o bexore treament \\
\hline & $1 / 2$ & $4\}$ & Light scald developed during marketing period. Treated 2 days \\
\hline & & 2\} & after harvest \\
\hline Winesap.... & 2 & 2 & $\begin{array}{l}\text { Fruit stored about } 50 \text { days prior to treatment. Scald developed } \\
\text { late in marketing period. Commercial significance uncertain }\end{array}$ \\
\hline \multirow[t]{3}{*}{ Yellow Newtown..... } & $1 / 2$ & 4 & Light-to-moderate scald developed during marketing period \\
\hline & 1 & 2 & Iight scald \\
\hline & 2 & 2 & Moderate-to-severe scald, loss of natural aroma \\
\hline \multicolumn{4}{|r|}{ 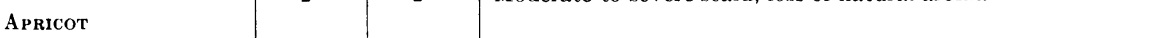 } \\
\hline Tilton. & 2 & 2 & $\begin{array}{l}\text { Brown spotting on most fruits developed soon after removal from } \\
41^{\circ} \mathrm{F} \text { tempreature to } 68^{\circ} \mathrm{F}\end{array}$ \\
\hline \multicolumn{4}{|r|}{ 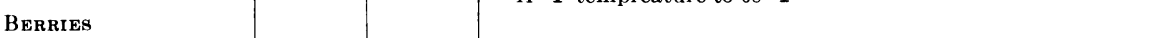 } \\
\hline Black raspberry... & 2 & 2 & Off-flavor recorded 4 days after treatment, 3 days $41^{\circ} \mathrm{F}, 1$ day $68^{\circ} \mathrm{F}$ \\
\hline Red Raspberry.... & $\begin{array}{l}1 / 2 \\
1,2\end{array}$ & $\left.\begin{array}{l}2,4 \\
2\end{array}\right\}$ & Loss of aroma. Tests and observations limited \\
\hline Strawberry... & 2 & 2 & Loss of aroma. Tests and observations limited \\
\hline \multicolumn{4}{|l|}{ Peaches } \\
\hline Fay Elberta.. & 2 & 2 & Loss of aroma \\
\hline Sunbeam...... & 2 & 2 & Loss of aroma \\
\hline \multicolumn{4}{|l|}{ Persimmons } \\
\hline Chienting. & 1 & 2 & All varieties failed to ripen properly after treatment in dosage \\
\hline Fuji....... & $1 / 2$ & 2,4 & range used. Outer flesh firm and somewhat leathery although \\
\hline & 1,2 & 2 & area near core softened \\
\hline Hachiya. . & . & . & \\
\hline Nishirazu. & . & . & \\
\hline
\end{tabular}

less, in the fumigation chamber, actual tolerance under commercial load conditions could be somewhat higher than indicated.

Commercial Shipments of Fumigated Fruits. Effective April, 1951, the Bureau of Entomology and Plant Quarantine, United States Department of Agriculture, approved ethylene dibromide (EDB) as a condition for certification of certain commodities moving from Hawaii to the mainland. The approved treatment called for a 2-hour-exposure period to a dosage of $1 / 2$ pound of EDB per 1,000 cubic feet of space, including that occupied by the commodity, at a temperature of at least $70^{\circ} \mathrm{F}$. At this writing, a regula- 
tion has been established approving ethylene chlorobromide (ECB) as an alternative condition for certification.

Should one of the species of fruit flies under quarantine regulations affecting shipments from Hawaii become established in California, similar regulations might be placed in effect covering interstate shipments.

The favorable laboratory results with ethylene dibromide and ethylene chlorobromide were secured primarily on small lots of fruit. It was conceivable that even though the fumigant residue flavor was dissipated by small lots in cold storage during a simulated transit period the off-flavor might persist in a confined carload of treated fruit during transit to distant markets. Since this question required an answer before commercial recommendations could be made, plans were developed for the fumigation of entire carloads of commercially packed fruit during the 1952 season.

New York Shipments. The first 2 cars destined for New York contained only apricots, except for several test packages each of Beauty, Santa Rosa, and Shiro plums, and Alexander peaches. The fruit was loaded warm into tight, dry, fan cars and treated at the rate of $3 / 4$ pound of fumigant per 1,000 cubic feet of total car space for 2 hours. One car was fumigated with ethylene dibromide and the other with ethylene chlorobromide, the fumigants atomized under pressure into the air blast of precooling fans. Fans were operated continuously during the treatment period. No leaks in either car could be found with a halide detector. Following fumigation the cars were vented for 45 minutes with fans operating, and then were iced and precooled for 24 hours. Untreated boxes of fruit were placed in the brace of the car just before precooling, to be used for comparison purposes. The cars arrived for the June 30 New York auction, 9 days after shipment. Test boxes were taken immediately for observation and tasting by a panel made up of 2 staff members of the University of California and 1 United States Department of Agriculture quarantine inspector for the Port of New York. No differences of any kind could be detected between treated and untreated lots of fruit, nor were any differences found between these fruits and similar varieties elsewhere on the auction market.

Chicago Shipments. A second shipment test was made to Chicago in late July, to test additional fruits and determine whether a shorter transit period of 6 days would have an effect on the dissipation of off-flavors from fumigant residue. The cars originated in the Loomis and Newcastle areas and were made up of the following fruit varieties: Burbank, Sharkey, Rayburn, Tragedy, El Dorado, Sugar, and Duarte plums, and Bartlett pears. In addition, test boxes of Thompson Seedless grapes, Halehaven peaches, and Gravenstein apples were included. One car was fumigated with ethylene chlorobromide, as previously described. The ethylene dibromide fumigation was done in a room previously used for methyl bromide fumigation of carload lots. Prior to this test the concrete was sealed with a waterproof paint. Treatment was again at the rate of $3 / 4$ pound per 1,000 cubic feet. Observations on the Chicago auction market were made by a representative of the University of California, federal inspectors, and other qualified judges. No differences between treated and untreated fruits were found.

The results of the shipping trials and the laboratory studies taken to- 
gether indicate: (1) that both ethylene dibromide and ethylene chlorobromide are safe commodity fumigants for nearly all deciduous fruits when used at a dosage of $3 / 4$ pound for 2 hours; and (2) that the margin of safety appears sufficient so that higher dosages could probably be used without danger.

\section{CHEMICAL STUDIES}

Chemical studies were made to develop information along 2 lines: (1) the amount of fumigant that could be recovered from air samples taken from within the fumigation chamber as influenced by such conditions as time after treatment and fruit load; and (2) the quantity of bromine residues in treated fruits as influenced by treatment dosage, exposure time, chamber load, and ventilation period. The first of these is important in relation to establishment of treatment requirements for quarantine purposes. The second is important in relation to possible food contamination; it also may be of considerable value in evaluating treatment dosages for sterilization under variable fruit loads.

\section{Recovery of Fumigant in Air Samples Taken from within Chamber and from Ampules}

As previously stated, both ethylene dibromide (EDB) and ethylene chlorobromide (ECB) have relatively high boiling points. Unlike methyl bromide, they must be vaporized by boiling or atomizing in a turbulent air stream. Chemical analyses were desirable, therefore, to assess extent of vaporization as well as to develop information regarding the influence of time and fruit load upon concentration changes.

Rauscher (1937) found that monoethanolamine was effective in absorbing and hydrolyzing both aliphatic and aromatic halogen compounds. Stenger et al. (1939) used monoethanolamine for determination of methyl bromide and found that an exposure time of 15 minutes was sufficient for nearly complete hydrolysis of the methyl bromide. The Volhard method was used for analyzing the bromide. Lewis (1945) reported a better recovery of methyl bromide by using a mixture of monoethanolamine and dioxane rather than monoethanolamine alone. Sinclair and Crandall (1952), using Stenger's method, had good results with methyl bromide but unsatisfactory results with EDB. However, they reported that heating the reaction flask to $90^{\circ} \mathrm{C}$ for 30 minutes effected complete hydrolysis of EDB. Phillips and Bulger (1952) reported that hydrolysis of EDB was improved either by extending the reaction time or by increasing the amount of monoethanolamine. They reported similar EDB recovery in chamber analyses when the reaction flask contained $3 \mathrm{ml}$ of monoethanolamine and was heated to $90^{\circ} \mathrm{C}$ for 30 minutes to when it contained $30 \mathrm{ml}$ of monoethanolamine and stood at room temperature for 30 minutes.

Sinclair and Crandall, and Phillips and Bulger had been studying bromine recovery from EDB and ECB concurrently with the present studies. The method described by Lewis (1945) was followed in the present studies. Gas samples were drawn from the fumigation chamber by means of evacuated flasks of about 1,100-ml capacity. A copper tube (later a glass tube) was ex- 
tended about 18 inches into the chamber at a height of about $21 / 2$ feet from the floor. One evacuated flask was used to flush the sampling tube, after which 2 flasks were used for air samples. Each of the latter contained $10 \mathrm{ml}$ of monoetharılamine plus dioxane, except in a few tests where a range of 3

TABLE 16

RECOVER.Y OF KNOWN AMOUNTS OF ETHYLENE DIBROMIDE ABSORBED IN MONOETHANOLAMINE

\begin{tabular}{|c|c|c|c|c|c|c|c|}
\hline \multicolumn{4}{|c|}{ Refluxed 30 minutes } & \multicolumn{4}{|c|}{$1 / 2$ hour in oven at $90^{\circ} \mathrm{C}$} \\
\hline \multirow{2}{*}{$\begin{array}{l}\text { Sample } \\
\text { number }\end{array}$} & \multirow{2}{*}{$\underset{\text { used }}{\mathrm{Mg}}$} & \multicolumn{2}{|c|}{ Recovered } & \multirow{2}{*}{$\begin{array}{l}\text { Sample } \\
\text { number }\end{array}$} & \multirow{2}{*}{$\underset{\text { used }}{\mathrm{Mg}}$} & \multicolumn{2}{|c|}{ Recovered } \\
\hline & & $\mathrm{Mg}$ & Per cent & & & $\mathrm{Mg}$ & Per cent \\
\hline 1. & 8.9 & 8.05 & 90.4 & $1 .$. & 36.3 & 34.5 & 95.0 \\
\hline 2 . & 10.2 & 9.20 & 90.2 & 2. & 38.1 & 35.5 & 93.2 \\
\hline 3 . & 10.7 & 9.89 & 92.4 & 3. & 19.1 & 17.6 & 91.2 \\
\hline $4 \ldots \ldots \ldots$ & 10.7 & 9.92 & 92.7 & 4. & 31.8 & 30.6 & 96.2 \\
\hline 5 & 12.3 & 11.31 & 92.0 & & 41.0 & 38.3 & 93.4 \\
\hline 6. & 12.8 & 11.77 & 92.0 & $6 .$. & 32.4 & 30.6 & 94.4 \\
\hline 7 & 14.2 & 13.38 & 94.2 & & 30.2 & 28.9 & 95.7 \\
\hline 8. & 14.6 & 14.08 & 96.4 & & & & \\
\hline 9. & 17.2 & 15.92 & 92.6 & & & & \\
\hline 10. & 17.6 & 16.09 & 91.2 & & & & \\
\hline $11 .$. & 17.6 & 16.09 & 91.2 & & & & \\
\hline 12 . & 18.0 & 16.38 & 91.0 & & & & \\
\hline 13. & 18.6 & 17.93 & 96.4 & & & & \\
\hline 14. & 20.6 & 19.61 & 95.2 & & & & \\
\hline 15. & 22.4 & 20.69 & 92.4 & & & & \\
\hline 16. & 24.9 & 24.78 & 99.5 & & & & \\
\hline 17. & 25.2 & 24.41 & 96.9 & & & & \\
\hline 18. & 28.1 & 24.83 & 88.4 & & & & \\
\hline 19. & 28.4 & 27.08 & 95.4 & & & & \\
\hline 20 . & 28.7 & 26.67 & 92.9 & & & & \\
\hline 21 . & 33.5 & 29.54 & 88.2 & & & & \\
\hline 22 . & 34.1 & 30.84 & 90.4 & & & & \\
\hline 23. & 35.9 & 31.76 & 88.5 & & & & \\
\hline 24 . & 35.9 & 34.97 & 97.4 & & & & \\
\hline 25 . & 36.1 & 31.30 & 86.7 & & & & \\
\hline 26 . & 36.3 & 31.50 & 86.8 & & & & \\
\hline 27 . & 36.4 & 33.36 & 91.6 & & & & \\
\hline $28 \ldots$ & 40.0 & 36.57 & 91.4 & & & & \\
\hline A verage ... & & & 92.3 & A verage. & $\ldots$ & & 94.2 \\
\hline
\end{tabular}

to $30 \mathrm{ml}$ of monoethanolamine was used. Following hydrolysis by long standing or heat the procedure was as follows:

Wash down with a minimum of distilled water; add $10 \mathrm{ml}$ of $6 \mathrm{~N}$ nitric acid and allow to cool; add $5 \mathrm{ml} 0.1 \mathrm{~N} \mathrm{AgNO}_{3}, 1 \mathrm{ml}$ ferric alum indicator, $1 \mathrm{ml}$ of 4 per cent thymol in ether, titrate with $0.05 \mathrm{~N}$ KSCN.

Table 16 shows recovery of known amounts of EDB from sealed glass ampules that were crushed under monoethanolamine. There seemed to be little difference in recovery between samples that were refluxed and those held in a $90^{\circ} \mathrm{C}$ oven for $1 / 2$ hour. Considerable difficulty was encountered 
with the oven method in holding ground-glass stoppers in the flasks, so a number of samples were lost.

Recoveries of ECB from ampules by various procedures of heating or standing are compared in table 17 in relation to percentage recovery.

TABLE 17

RECOVERY OF KNOWN AMOUNTS OF ETHYLENE CHLOROBROMIDE ABSORBED IN MONOETHANOLAMINE

\begin{tabular}{|c|c|c|c|c|c|}
\hline \multirow{2}{*}{ Sample number } & \multirow{2}{*}{$\underset{\text { used }}{\mathrm{Mg}}$} & \multicolumn{2}{|c|}{ Recovered } & \multirow{2}{*}{$\begin{array}{l}\text { Variations in analytical } \\
\text { procedure }\end{array}$} & \multirow{2}{*}{$\begin{array}{c}\begin{array}{c}\text { Average } \\
\text { recovery }\end{array} \\
\text { Per cent }\end{array}$} \\
\hline & & $\mathrm{Mg}$ & Per cent & & \\
\hline 1. & 18.3 & 16.9 & 92.3 & Reflux -30 minutes. & \\
\hline 2. & 16.6 & 14.8 & 89.2 & Reflux -30 minutes......... & \\
\hline $3 \ldots \ldots$ & 30.2 & 28.2 & 93.4 & Reflux -30 minutes.......... & 92.4 \\
\hline $4 \ldots \ldots \ldots \ldots \ldots \ldots$ & 29.5 & 28.2 & 95.6 & Reflux -30 minutes....... & \\
\hline $5 \ldots \ldots \ldots \ldots \ldots \ldots$ & 17.7 & 16.2 & 91.5 & Reflux -30 minutes.......... & \\
\hline 6 & 22.1 & 20.5 & 92.8 & 30 minutes in $90^{\circ} \mathrm{C}$ oven.... & \\
\hline 7 & 16.9 & 15.7 & 92.9 & 30 minutes in $90^{\circ} \mathrm{C}$ oven.... & 92.8 \\
\hline 8. & 21.5 & 19.9 & 92.6 & 30 minutes in $90^{\circ} \mathrm{C}$ oven.... & \\
\hline 9 . & 34.0 & 29.9 & 87.9 & $1 \mathrm{hr}$. in $90^{\circ} \mathrm{C}$ oven.. & \\
\hline 10. & 29.6 & 29.5 & 99.7 & $1 \mathrm{hr}$. in $90^{\circ} \mathrm{C}$ oven. . & \\
\hline 11. & 9.0 & 8.1 & 90.0 & $1 \mathrm{hr}$. in $90^{\circ} \mathrm{C}$ oven. & 92.9 \\
\hline 12. & 25.9 & 24.1 & 94.2 & $1 \mathrm{hr}$. in $90^{\circ} \mathrm{C}$ oven. . & \\
\hline 13. & 24.9 & 24.7 & 99.2 & 2 hours in $90^{\circ} \mathrm{C}$ oven.. & \\
\hline $14 \ldots$ & 40.0 & 34.9 & 87.3 & 2 hours in $90^{\circ} \mathrm{C}$ oven... & 93.1 \\
\hline $15 \ldots \ldots \ldots \ldots \ldots$ & 25.5 & 23.7 & 92.9 & 2 hours in $90^{\circ} \mathrm{C}$ oven ........ & \\
\hline 16. & 19.2 & 18.9 & 98.4 & 3 hours in $90^{\circ} \mathrm{C}$ oven... & \\
\hline 17. & 10.8 & 10.3 & 95.4 & 3 hours in $90^{\circ} \mathrm{C}$ oven ........ & 94.3 \\
\hline $18 \ldots \ldots \ldots \ldots \ldots \ldots$ & 25.4 & 22.6 & 89.0 & 3 hours in $90^{\circ} \mathrm{C}$ oven ........ & \\
\hline 19. & 21.7 & 20.6 & 94.9 & 65 hours at $68^{\circ} \mathrm{F}$. & ) \\
\hline $20 \ldots$ & 14.3 & 13.1 & 91.6 & 65 hours at $68^{\circ} \mathrm{F}$. & 95.5 \\
\hline 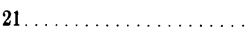 & 9.9 & 9.9 & 100 & 65 hours at $68^{\circ} \mathrm{F}$. & \\
\hline 22. & 30.4 & 26.9 & 88.5 & 18 hours at $68^{\circ} \mathrm{F}$. & \\
\hline $23 \ldots$ & 24.6 & 22.1 & 89.8 & 18 hours at $68^{\circ} \mathrm{F}$. & \\
\hline $24 \ldots$ & 13.7 & 12.3 & 89.8 & 18 hours at $68^{\circ} \mathrm{F}$. & 89.2 \\
\hline 25 . . & 14.3 & 12.1 & 84.6 & 18 hours at $68^{\circ} \mathrm{F}$. & \\
\hline $26 \ldots \ldots \ldots$ & 26.2 & 24.5 & 93.5 & 18 hours at $68^{\circ} \mathrm{F}$. & \\
\hline
\end{tabular}

Whether the monoethanolamine plus dioxane was refluxed for 30 minutes and held in a $90^{\circ} \mathrm{C}$ oven for periods ranging from 30 minutes to 3 hours or allowed to stand in the reaction flask for $2 \frac{1}{2}$ days, recoveries were essentially the same. Variations in average recovery could be accounted for by one reading. There seemed to be a definite reduction in recovery when the only procedure was to allow the reaction flask to stand at $68^{\circ} \mathrm{F}$ for 18 hours before analysis.

The EDB and ECB used in these studies were supplied by the Dow Chemical Company and repurified by them from 96 per cent commercial stock. Although the exact purity is not known, both chemicals are believed to have been between 96 and 98 per cent pure. This should be considered in evaluating data on chemical recovery. 


\section{Analysis for Bromine of Air from Fumigation Chamber}

Chemical studies made in the earlier stages of this investigation revealed a very low recovery of bromine from air samples taken during fumigation. Such data are not presented here, although the influence of time and fruit load on relative recovery was similar in pattern to that secured after procedures were developed for more complete hydrolysis of the bromine compounds. The data presented in table 18 give the recovery of EDB from an

TABLE 18

RECOVERY OF ETHYLENE DIBROMIDE FROM EMPTY FUMIGATION CHAMBER BY IMPROVED METHOD FOR HYDROLIZING BROMIDES, WITH EACH SAMPLE REFLUXED 30 MINUTES AND ONE HOUR IN $90^{\circ} \mathrm{C}$ OVEN

\begin{tabular}{|c|c|c|c|c|c|}
\hline \multirow{2}{*}{ Date } & \multirow{2}{*}{$\begin{array}{c}\text { Treat- } \\
\text { ment, } \\
\text { lbs per } \\
1,000 \\
\text { cu ft }\end{array}$} & \multicolumn{3}{|c|}{$\begin{array}{l}\text { Per cent recovery at intervals } \\
\text { following treatment }\end{array}$} & \multirow{2}{*}{$\begin{array}{c}\text { Remarks regarding conditions } \\
\text { of treatment }\end{array}$} \\
\hline & & $15 \mathrm{~min}$ & $60 \mathrm{~min}$ & $120 \mathrm{~min}$ & \\
\hline $7 / 2 / 52$. & 2 & 73.2 & 57.5 & 52.2 & \\
\hline $7 / 10 / 52$. & 2 & 65.5 & 52.0 & 47.2 & Motor driven portable atomizer \\
\hline $9 / 8 / 52$ & 2 & 70.0 & 64.5 & 60.5 & \\
\hline $12 / 4 / 52$ & 2 & 69.7 & 61.7 & 50.0 & \\
\hline $12 / 9 / 52$ & 1 & 80 & 74 & 68.5 & \\
\hline $12 / 10 / 52$ & 1 & 74.5 & 66 & 61 & \\
\hline $1 / 5 / 53^{*}$ & 1 & 81 & 68 & 62 & \\
\hline $1 / 7 / 53 \ldots$ & 1 & 73.5 & 69.5 & 62.5 & \\
\hline $1 / 13 / 53 \ldots \ldots$ & 1 & 84 & 69.5 & 65.5 & \\
\hline $1 / 27 / 53 \ldots \ldots$ & 1 & 74 & 69.5 & 63 & \\
\hline $2 / 2 / 53 \ldots \ldots \ldots$ & 1 & 92.4 & 83.5 & 80.6 & Spray nozzle in direct air blast \\
\hline $2 / 9 / 53 \ldots \ldots \ldots$ & 1 & 87.8 & 79.6 & 70.9 & Spray nozzle in direct air blast \\
\hline $2 / 9 / 53 \ldots$ & 1 & 84.2 & 68.6 & 61.4 & \\
\hline
\end{tabular}

* Aluminum foil over door and vent rubber seals, on and after January 5, 1953.

empty chamber, using improved methods for hydrolyzing bromides. Recovery seemed somewhat better when the atomizing nozzle was directly in front of the fan. Covering the rubber seals with aluminum foil may have helped to reduce EDB losses, but the improvement was relatively minor. Regardless of the procedure used in operating the metal-lined fumigation chamber, it was impossible to recover all of the EDB, even at the 15-minute interval. Subsequent analyses of samples taken 1 hour and 2 hours after treatment began showed a continued loss of fumigant.

Table 19 shows the recovery of ECB from an empty chamber as related to the procedure of handling air samples. The percentage recovery seems fairly good when the air sample is allowed to stand in the flask in contact with monoethanolamine plus dioxane for a day or longer before titration, or when hydrolysis is hastened by heat. The percentage recovery is progressively less as the contact period at room temperature is reduced below 24 hours. ECB losses from the air in the fumigation chamber are similar in pattern to losses of EDB.

No direct evidence is available as to what happens to the fumigant lost 
from the atmosphere in the chamber. It is usually assumed to be sorbed on the walls and other surfaces. Some of it may have been lost by leakage through rubber seals, but any such losses were not detectable with a halide detector. Figure 11 shows the percentage recovery from an empty chamber of the 3 most promising fumigants used-methyl bromide, ethylene dibromide, and ethylene chlorobromide. The recovery curves may partly reflect

TABLE 19

RECOVERY OF ETHYLENE CHLOROBROMIDE FROM EMPTY FUMIGATION CHAMBER AT DIFFERENT INTERVALS FOLLOWING TREATMENT, RELATED TO CONTACT TIME WITH MONOETHANOLAMINE

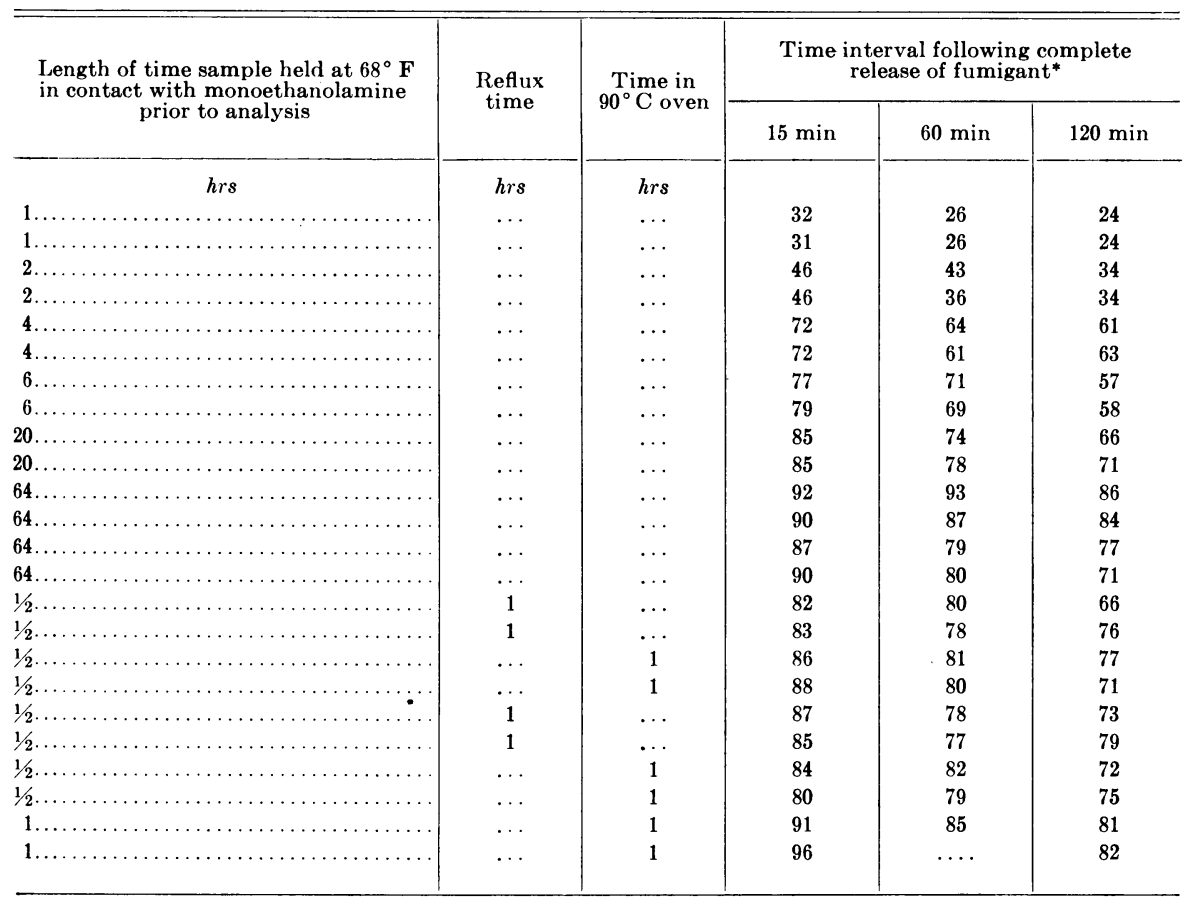

* Fumigant vaporized by atomizing in turbulent air stream.

the suitability of the chemical procedures used in determining bromine in various bromides, but there may be real differences in sorption and other losses from the fumigation chamber that are directly related to the various chemicals. The methyl bromide curve is based upon somewhat more limited data than are the other curves since nearly all methyl bromide tests were made in another chamber.

The influence of fruit load upon fumigant concentration was studied by loading the fumigation chamber in turn with 25, 50, 75, and 100 field lugs, or their equivalent, of the fruits available. One hundred field lug boxes occupy about 144 cubic feet ( 57 per cent of the space) and are considered to be a full commercial load. Therefore, package-load figures also represent percentage fill. Figures 12 and 13 show data from EDB concentration with dif- 


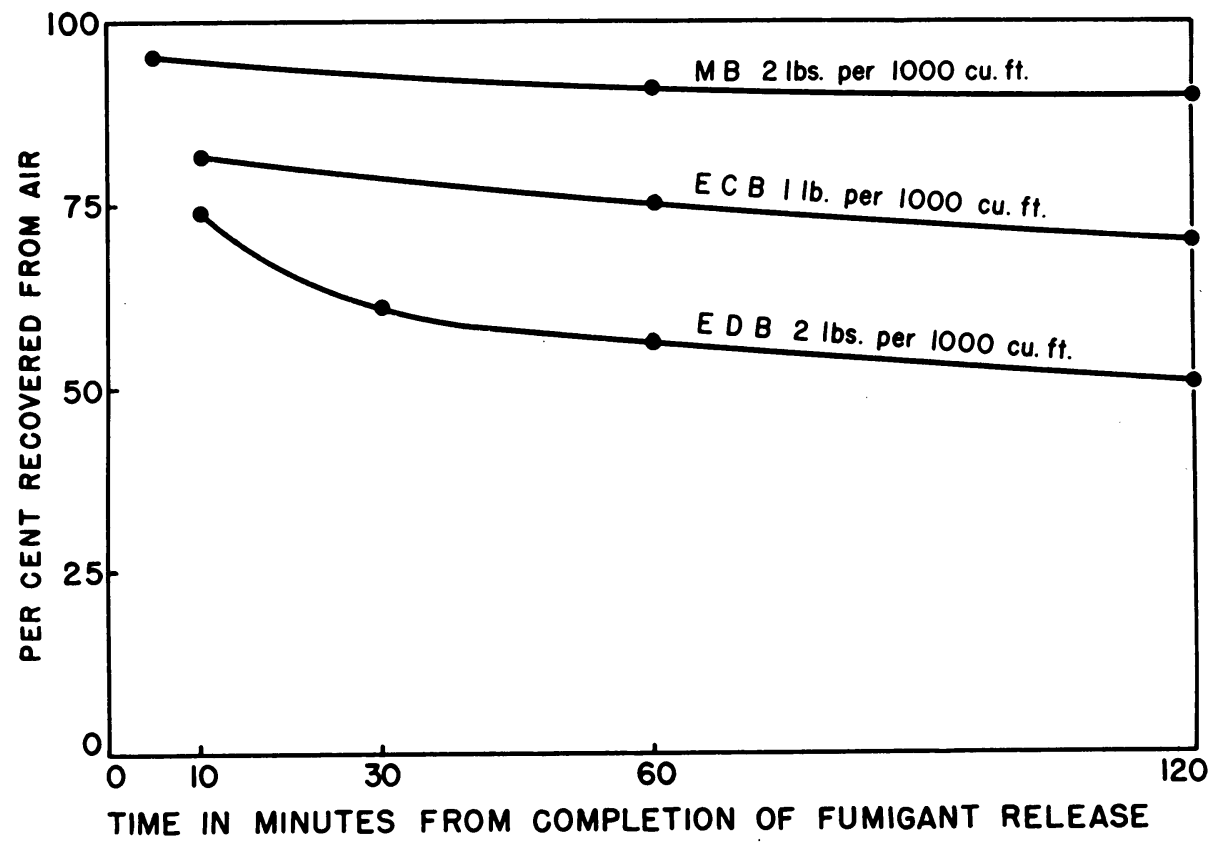

Fig. 11. Recovery of ethylene dibromide, ethylene chlorobromide, and methyl bromide from fumigation chamber.

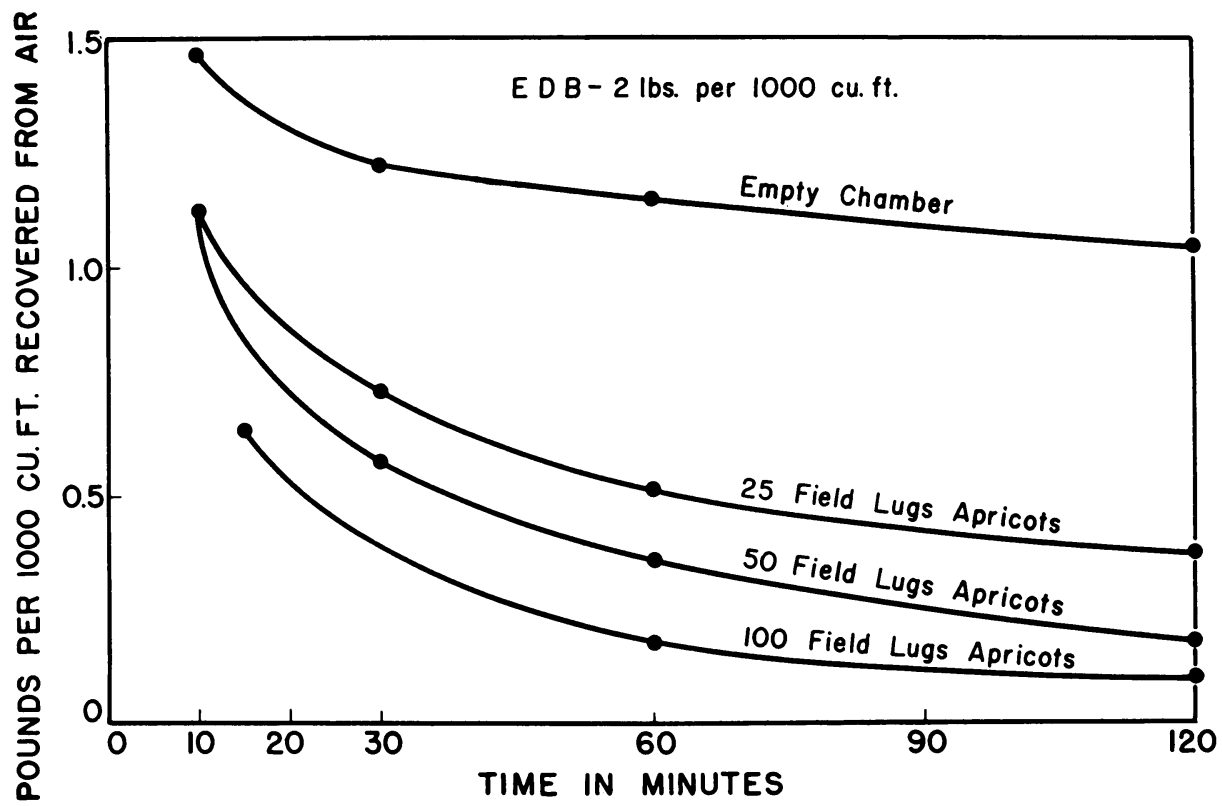

Fig. 12. Recovery of ethylene dibromide from air in fumigation chamber under different load conditions with apricots. 
ferent loads of apricots and pears; figure 14 shows similar data for ECB with apricots. The relative amount of fruit in the chamber has a very important influence on rate of fumigant depletion and extent of depletion.

Since both EDB and ECB are slightly soluble in water, a movement of fumigant from the air to the water of the fruit tissue would be expected. The data on bromine residues will give information on this subject. No data were secured for methyl bromide regarding fumigant depletion in relation to fruit load. However, because of its much lower solubility in water, somewhat less depletion might be expected.

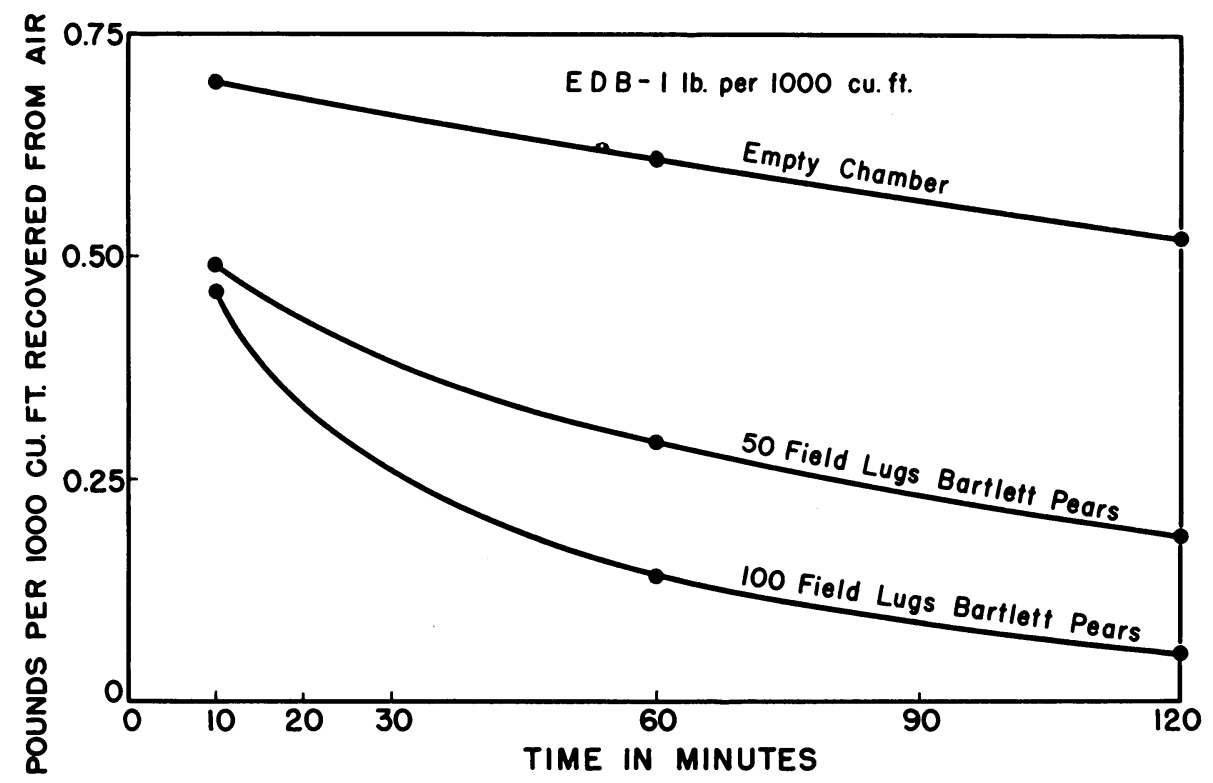

Fig. 13. Recovery of ethylene dibromide from air in fumigation chamber under different load conditions with Bartlett pears.

\section{Bromine Residue in Fumigated Fruits}

Residue analyses for bromine were made primarily on fruits fumigated with ethylene dibromide (EDB). Information is available elsewhere on bromine residue recovered from fruits treated with methyl bromide. Although several fruit species were used in the residue work, the greatest amount of data was secured on Yellow Newtown apples, a long-keeping variety that made residue studies possible during the winter months.

The method of Shrader, Beshgetoor, and Stenger (1942) was used for most of the analyses, but a change was made at a later stage of the work to a wet ash method (Association of Official Agricultural Chemists, 1950) for determining bromine in dyes. The method is somewhat more rapid than that of Shrader et al., but required some modifications to make it adaptable to larger amounts (10 gm) of organic material. Ten $\mathrm{ml}$ of alcoholic $\mathrm{NaOH}$ was used in place of $2 \mathrm{ml}$ of $\mathrm{NaOH}$, and the amount of chromate solution was increased from 5 to $25 \mathrm{ml}$ to provide complete digestion of the fruit tissue. In both of 
these methods half of the bromine from EDB is lost as vinyl bromide as a result of the reaction of $\mathrm{EDB}$ with alcoholic $\mathrm{KOH}$ and $\mathrm{NaOH}$. Therefore, the results secured after subtracting the reagent blank were multiplied by two. The reagent blank in the AOAC method was always zero. If part of the bromine in EDB should react chemically with the fruit tissue, this calculation would not be valid, as vinyl bromide would not necessarily be formed

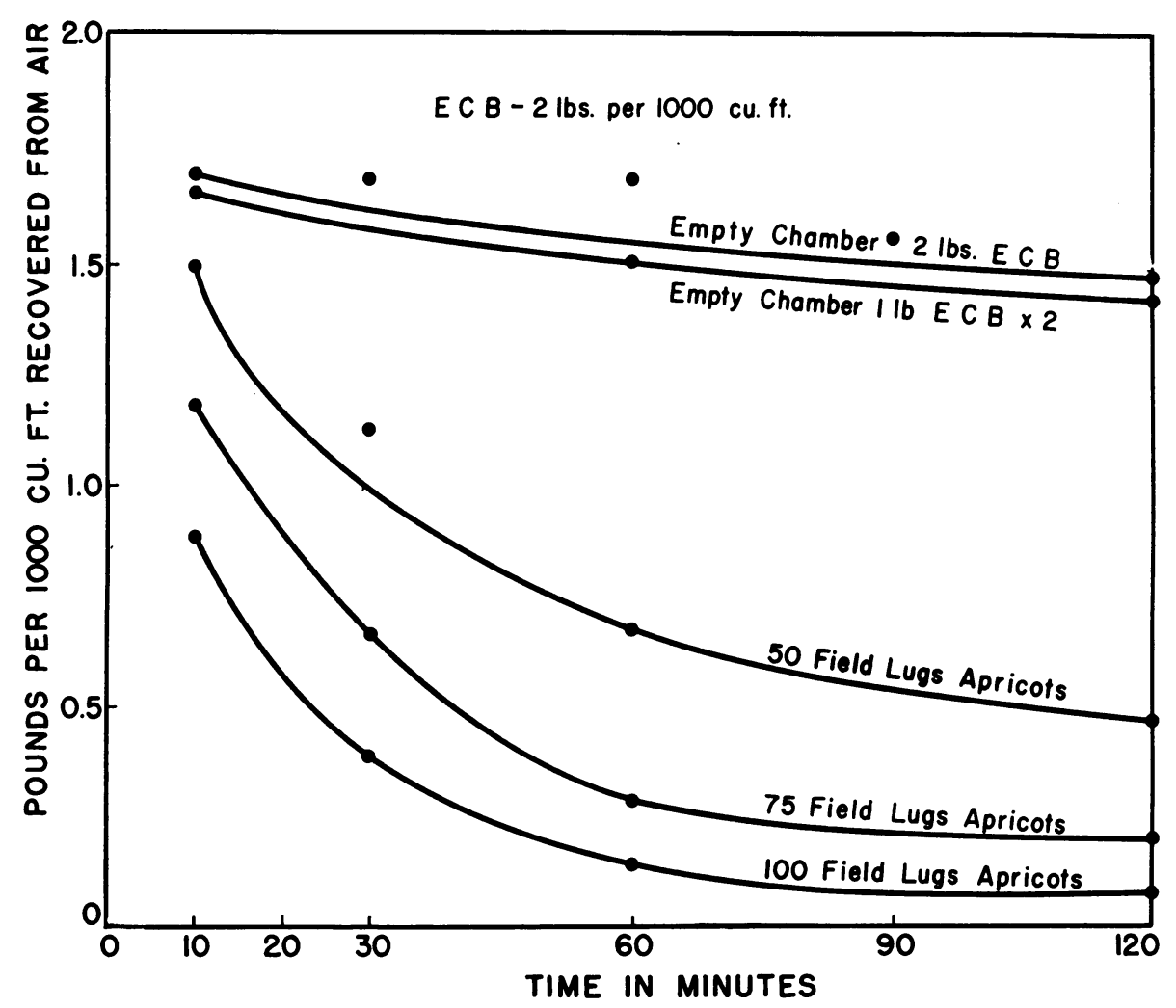

Fig. 14. Recovery of ethylene chlorobromide from air in fumigation chamber under different load conditions with apricots.

in similar amounts. However, since the residue always approached zero with time, it is thought that the procedure is acceptable.

Table 20 shows the data secured from Yellow Newtown apples treated with different concentrations of EDB ranging from $1 / 2$ to 2 pounds per 1,000 cubic feet of space. These studies were all made with fruit treated in the 252-cubic-foot chamber with a fruit load only 1 to 2 per cent of capacity. As expected, the amount of bromine found in the fruit increased with treatment dosage. Extending treatment time from 2 to 4 hours also increased the residue, somewhat in proportion to the time factor. Aeration of the fruit following treatment, even at $41^{\circ} \mathrm{F}$, resulted in a fairly rapid loss of bromine residue, with complete loss usually occurring within a week to 10 days. 
Since EDB is slightly soluble in water it is important to know the influence of chamber load upon tolerance studies of fruits. This information had not been developed at the time that load studies in relation to fumigant recovery from the air were made for the large chamber. A procedure was devised for using 5-gallon glass jars as fumigation chambers in making residue studies in relation to fruit load. The data secured from a number of tests are shown in table 21. As fruit load is increased in the fumigation chamber the amount of EDB sorbed by a unit weight of fruit tissue is correspondingly reduced. An increase in EDB sorbed accompanies an increase

TABLE 20

BROMINE RESIDUE IN YELLOW NEWTOWN APPLES FUMIGATED WITH ETHYLENE DIBROMIDE*

\begin{tabular}{|c|c|c|c|c|c|c|c|c|c|c|c|}
\hline \multirow{2}{*}{$\begin{array}{c}\text { Date } \\
\text { fumigated }\end{array}$} & \multirow{2}{*}{ Dosage } & \multirow{2}{*}{ Time } & \multicolumn{9}{|c|}{ Bromine recovery in ppm fresh weight at various days after fumigation } \\
\hline & & & 0 & 1 & 2 & 3 & 4 & 5 & 6 & 7 & 8 \\
\hline & $l b s$ & $h r s$ & & & & & & & & & \\
\hline $2 / 5 / 52$. & $1 / 2$ & 2 & 10.6 & 3.4 & 3.4 & $\ldots$ & $\ldots$ & 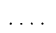 & 2.2 & 1.8 & $\ldots$ \\
\hline $2 / 13 / 52$. & $1 / 2$ & 2 & 8.4 & 3.2 & $\ldots$ & $\cdots$ & $\ldots$ & 3.0 & 1.0 & $\ldots$ & $\ldots$ \\
\hline $3 / 17 / 52$. & $1 / 2$ & 2 & 11.2 & 4.2 & 2.6 & 4.8 & $\ldots$ & $\ldots$ & $\ldots$ & $\ldots$ & $\ldots$ \\
\hline $2 / 18 / 52$. & $1 / 2$ & 4 & 12.4 & 8.2 & $\ldots$ & $\ldots$ & $\ldots$ & $\ldots$ & $\ldots$ & $\ldots$ & 1.4 \\
\hline $2 / 27 / 52 \ldots$ & $1 / 2$ & 4 & 15.4 & 10.8 & 9.8 & $\cdots$ & $\cdots$ & $\ldots$ & 3.0 & 2.0 & $\ldots$ \\
\hline $1 / 22 / 52 \ldots \ldots \ldots$ & 1 & 2 & 25.0 & 7.8 & 5.8 & 4.4 & $\ldots$ & $\ldots$ & $\ldots$ & 0.2 & $\ldots$ \\
\hline $3 / 24 / 52 \ldots \ldots$ & 1 & 2 & & 14.6 & 13.0 & 8.0 & $\ldots$ & $\ldots$ & $\ldots$ & $\ldots$ & $\ldots$ \\
\hline $3 / 31 / 52$. . & 1 & 2 & 73.8 & 22.0 & 8.4 & 7.0 & $\ldots$ & $\ldots$ & $\ldots$ & $\ldots$ & $\ldots$ \\
\hline $4 / 7 / 52 \ldots$ & 2 & 2 & 95.8 & 57.6 & 33.8 & 8.8 & $\ldots$ & $\ldots$ & $\ldots$ & $\ldots$ & $\ldots$ \\
\hline $5 / 5 / 52$ & 2 & 2 & 79.6 & 28.2 & 20.2 & $\ldots$ & 9.8 & $\ldots$ & $\ldots$ & $\ldots$ & $\ldots$ \\
\hline
\end{tabular}

* Using method of Shrader, Beshgetoor, and Stenger.

in fumigant concentration, following a pattern similar to that shown in table 20 . When fruit load was reduced to 1 to 2 per cent in the large chamber, as was frequently done, the EDB sorption was much higher than in any of the loads in the 5-gallon containers. In fact, the residue shortly after treatment was 5 to 7 times as high as in the jar with a 75 per cent load.

\section{Discussion}

Treatment Conditions. The chemical data indicate that fruit fumigated with $\mathrm{EDB}$ in a partially filled chamber is subjected to much more severe treatment conditions than is fruit in a commercially filled space, with the difference in severity closely related to the relative space occupied. Therefore, in most of the fruit-tolerance studies conducted in the large chamber, the fruits were subjected to much higher fumigant dosages than would be fruits in commercial operations. The figures of fruit tolerance to various fumigants should be considered with this in mind. Fruit tolerances listed for ECB and EDB probably have an excellent margin of safety because of the small amount of fruit in the chamber during most of the fumigation tests.

Dosage Requirements. If a fumigation procedure is required in which $\mathrm{EDB}$ or ECB is used as a fumigant, equivalent treatment cannot be secured by calculating dosage strictly on a space basis. A way must be devised to 
allow for both space and fruit load in calculating dosage requirements. For full chamber loads only a small amount of fumigant is left in the atmosphere after 2 hours, so a longer fumigation period would appear to be of value primarily in maintaining fumigant concentration in the fruit in a static condition for a longer period. Since a chamber filled with fruit rapidly depletes $\mathrm{EDB}$ and $\mathrm{ECB}$ from the atmosphere it seems likely that the fumigant losses under these conditions not accounted for by sorption of fruits are much less than those shown for an empty chamber.

TABLE 21

BROMINE RESIDUE IN YELLOW NEWTOWN APPLES FUMIGATED WITH ETHYLENE DIBROMIDE*

\begin{tabular}{|c|c|c|c|c|c|c|}
\hline \multirow{2}{*}{ Treatment } & \multirow{2}{*}{$\begin{array}{l}\text { Per cent } \\
\text { load in jar }\end{array}$} & \multicolumn{5}{|c|}{ Bromine recovery in $\mathrm{ppm}$ fresh weight at various days after fumigation } \\
\hline & & 0 & 1 & 2 & 5 & 7 \\
\hline \multirow[t]{9}{*}{$1 / 2 \mathrm{lb}, 2 \mathrm{hrs} . . . \ldots}$. & 10 & 31 & 23 & 17 & 10.7 & . \\
\hline & 25 & 20 & 14 & 1 & $\ldots$ & 0 \\
\hline & 25 & 13 & 12 & 3 & $\ldots$ & 0 \\
\hline & 50 & 9 & 7 & 1 & $\ldots$ & 0 \\
\hline & 50 & 12 & 11 & 7 & $\ldots$ & 0 \\
\hline & 75 & 10 & 6 & 6 & $\cdots$ & 0 \\
\hline & 75 & 8 & 7 & .. & $\ldots$ & .. \\
\hline & Chamber $\dagger$ & 76 & 68 & 53 & $\ldots$ & 14 \\
\hline & Chamber $\dagger$ & 59 & 54 & 21 & $\ldots$ & 21 \\
\hline \multirow[t]{5}{*}{$1 \mathrm{lb}, 2 \mathrm{hrs} . \ldots \ldots$} & 10 & 79 & 29 & 26 & $\ldots$ & 17 \\
\hline & 25 & 44 & 31 & 17 & $\ldots$ & 12 \\
\hline & 50 & 28 & 15 & 13 & $\ldots$ & 13 \\
\hline & 75 & 17 & 10 & 5 & $\ldots$ & 0 \\
\hline & Chamber $t$ & 87 & 55 & 33 & $\ldots$ & 15 \\
\hline \multirow[t]{5}{*}{$2 \mathrm{lhs}, 2 \mathrm{hrs}}$. & 10 & 90 & 38 & 27 & $\ldots$ & 12 \\
\hline & 25 & 62 & 39 & 25 & $\ldots$ & 9 \\
\hline & 50 & 37 & 25 & 24 & $\ldots$ & 11 \\
\hline & 75 & 23 & 12 & 8 & $\ldots$ & 1 \\
\hline & Chamber $\dagger$ & 145 & 132 & 84 & $\ldots$ & 11 \\
\hline
\end{tabular}

* Using AOAC wet ash method.

$\dagger$ These treatments were made in 252-cubic-foot chamber filled only 1 to 2 per cent of capacity.

\section{RESPIRATION STUDIES}

Carbon dioxide production by fruits may be a useful measure of the influence of various fumigation treatments upon physiological processes. If a treatment hastens or depresses $\mathrm{CO}_{2}$ production some influence on subsequent ripening processes may also be expected. For example, methyl bromide $\left(\mathrm{CH}_{3} \mathrm{Br}\right)$ under certain concentrations and time exposures has been shown (Claypool, 1941) to accelerate the rate of $\mathrm{CO}_{2}$ production of Bartlett pears, also hastening the ripening process. The effect of a $\mathrm{CH}_{3} \mathrm{Br}$ treatment of 2 pounds for 2 hours was somewhat similar to an ethylene treatment. When used on mature green tomatoes methyl bromide caused an immediate and rapid increase in $\mathrm{CO}_{2}$ production, followed by a sharp decline, leveling off well below the control (Knott and Claypool, 1940). Fruit ripening was slowed considerably and the fruits became susceptible to attack by various fungi. 
The fact that a fumigant affects respiration does not necessarily mean that it damages the fruit. However, it does indicate that the physiology of the fruit is being influenced and that studies are desirable to determine whether the influence is harmful.

Many respiration studies of fumigated fruits were made in connection with the commodity tolerance work. This involved most of the fumigants used in the program and many species and varieties of fruit. Naturally, the most emphasis was placed upon the chemicals that gave the greatest promise as commercial fumigants for fresh fruits: methyl bromide, ethylene dibromide, and ethylene chlorobromide.

Most fruits used in the respiration studies were fumigated in 5-gallon glass containers, as described above. Duplicate samples of 1,000 to $1,200 \mathrm{gm}$ were placed in 1-gallon respiration chambers through which air was passed at a known constant rate. The containers were held in a constant-temperature room of $68^{\circ}$ to $70^{\circ} \mathrm{F}$ and $\mathrm{CO}$, determinations made at daily or twice-daily intervals by a colorimetric method (Claypool and Keefer, 1942).

Chemicals that seriously injured the fruit, such as acrylonitrile, chloroacetonitrile, and 1-chloro-3-bromopropene, caused an initial high $\mathrm{CO}_{2}$ release. At lowest fumigant concentrations $\mathrm{CO}_{2}$ production following treatment usually continued for some time at a high level in comparison with the controls. At higher fumigant concentrations where injury was severe, $\mathrm{CO}_{2}$ production dropped rapidly and remained at a low level. Probably this was due to a large amount of seriously damaged or necrotic tissue resulting from the treatment.

Typical data for methyl bromide, ethylene dibromide (EDB), and ethylene chlorobromide (ECB) are presented in figures 15 through 20. Figures 15 and 16 compare the response of Beauty plums to methyl bromide and EDB. The data are not directly comparable, because of slight differences in initial maturity and differences in fumigant concentration, but they do represent typical respiration curves and can be evaluated with respect to treated control lots. An EDB dosage of $1 / 2$ pound, 2 hours is approximately as lethal to the Oriental fruit fly as a methyl bromide dosage of 2 pounds, 4 hours. Therefore, although these bromide dosages differ considerably they are somewhat comparable in insecticidal value, which would regulate their commercial use. Beauty plums fumigated with methyl bromide were slightly less mature than those fumigated with EDB, as shown by the respiration curves of the 2 control lots; but they ripened in less time, as indicated by the attainment of maximum respiration. The difference between treated and control fruit was much greater when methyl bromide was used than when EDB was applied. These data indicate that methyl bromide influences the physiology of Beauty plums more than does EDB.

Figures 17 and 18 compare the effects of EDB and ECB on the respiration rate and ripening of Bartlett pears. Maximum dessert quality is attained at about the peak of respiration. The respiration rate is increased by either treatment, but not greatly, and the treated pears ripen a little faster than do the controls. When treatment of 2 pounds, 4 hours with ECB is removed from consideration (because preliminary information indicates that it is well above commercial dosage) the curves for the 2 fumigants are very similar. 


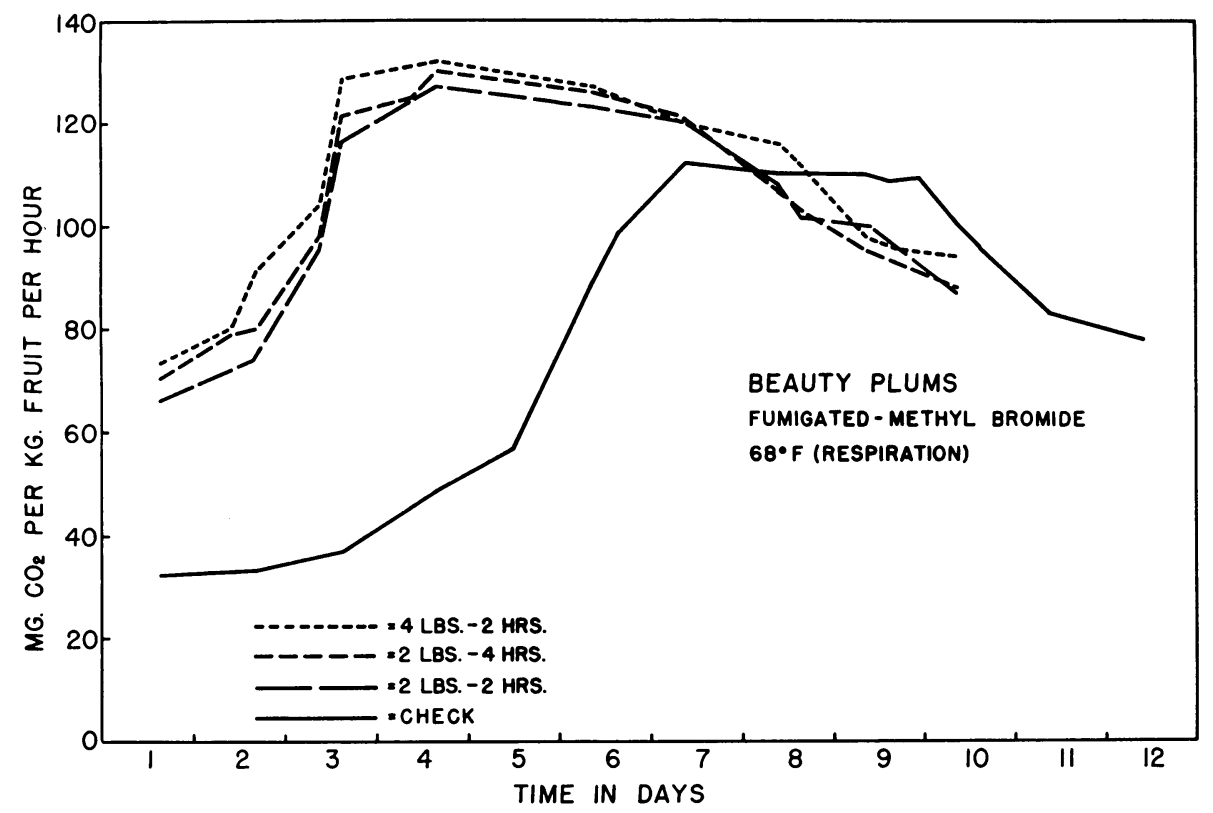

Fig. 15. Carbon dioxide evolution from Beauty plums fumigated with methyl bromide.

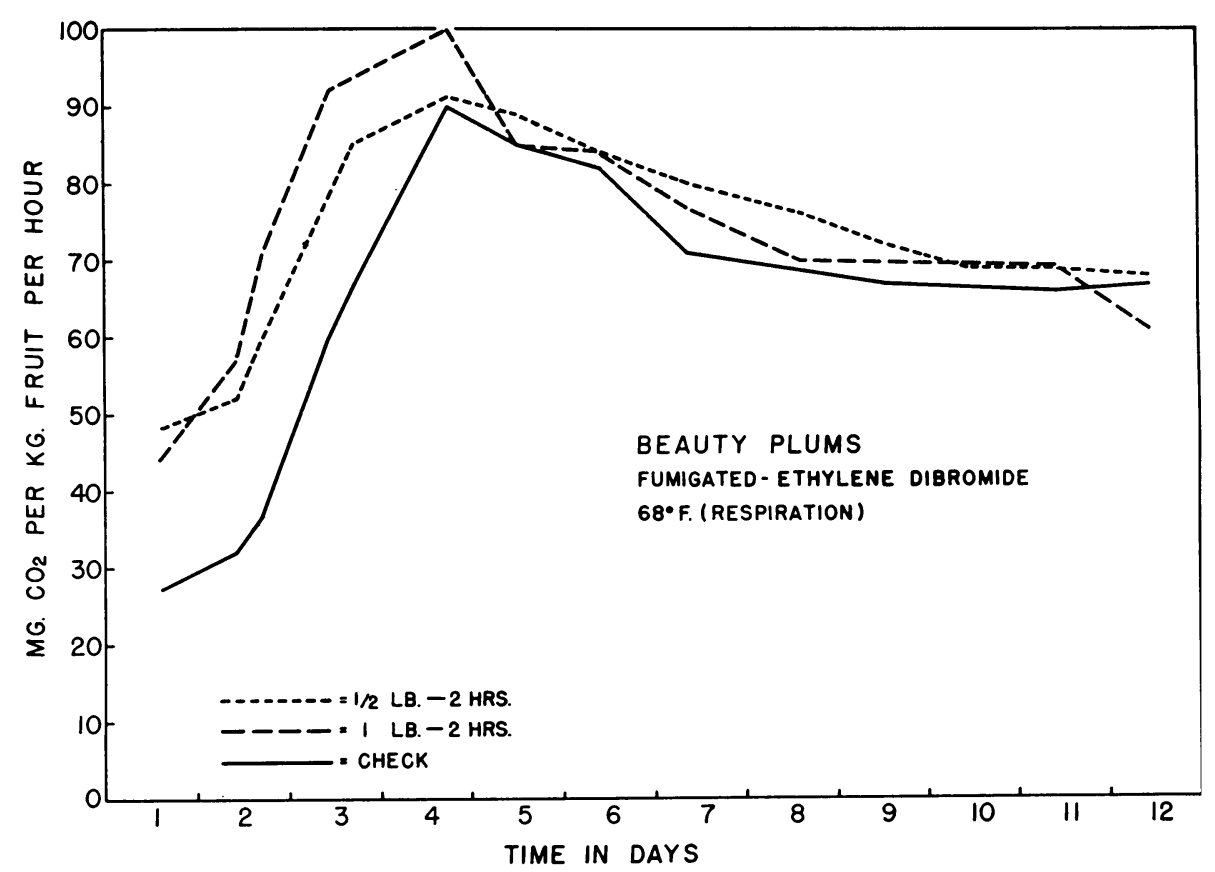

Fig. 16. Carbon dioxide evolution from Beauty plums fumigated with ethylene dibromide. 
They certainly indicate that neither EDB nor ECB has a marked effect on the physiology of Bartlett pears as measured by $\mathrm{CO}_{2}$ production.

The data secured on apples were not obtained with a single variety. The Gravenstein variety fumigated with ECB was definitely preclimacteric, as indicated (fig. 19) by the respiration increase in all lots. The respiration peak was reached only slightly earlier in the treated lots. The Golden Delicious apples were at or very near the climacteric peak of respiration at the time of treatment, as is indicated by the slope of the $\mathrm{CO}_{2}$ curve for the control lot. However, the apples fumigated with methyl bromide had a greatly accelerated $\mathrm{CO}_{2}$ production and attained a very high peak. Furthermore, the respiration rate never dropped to the level of the control fruit. This is further evidence that methyl bromide has a somewhat greater physiological effect than does ECB.

Figure 20 is presented to show the influence of 1 fumigant on the respiration of an Oriental persimmon variety. Persimmons were not tolerant to any of the fumigants used in these experiments. The influence of methyl bromide upon respiration rate, as measured by $\mathrm{CO}_{2}$ evolution, was the greatest secured in many years of experiments with different fruits. It was not determined whether other fumigants have effects of similar magnitude on persimmons, nor is it presently practical to theorize on the reasons for this effect. It does appear, however, that Oriental persimmons would be a suitable subject for enzyme studies.

The respiration studies presented here compare typical results secured from fruits fumigated with various dosages of methyl bromide, EDB, and ECB. Methyl bromide seems to influence $\mathrm{CO}_{2}$ production somewhat more than do the 2 other fumigants and therefore may be considered to be somewhat more active physiologically. Both $\mathrm{EDB}$ and $\mathrm{ECB}$ influence $\mathrm{CO}_{2}$ production but must be considered only slightly active physiologically at the dosages used. These results support commodity-tolerance data on the appearance, ripening, and flavor effects of these 3 fumigants and indicate that $\mathrm{CO}_{2}$ production may be a useful comparative measure of the responses of fruits to fumigants.

Nоте: Much of the information contained in this report was presented originally during the period from 1950 through 1952 in the commodity treatment section of various quarterly reports mimeographed by the United States Department of Agriculture, Bureau of Entomology and Plant Quarantine, under the title of "Investigations of Fruit Flies in Hawaii." A summary of much of the information developed in this study was published in 1953 as a part of a publication by the Senate of the State of California for the Joint Legislative Committee on Agriculture and Livestock Problems and entitled "Third Special Report on the Control of the Oriental Fruit Fly (Dacus dorsalis) in the Hawaiian Islands," pages $100-117$. 


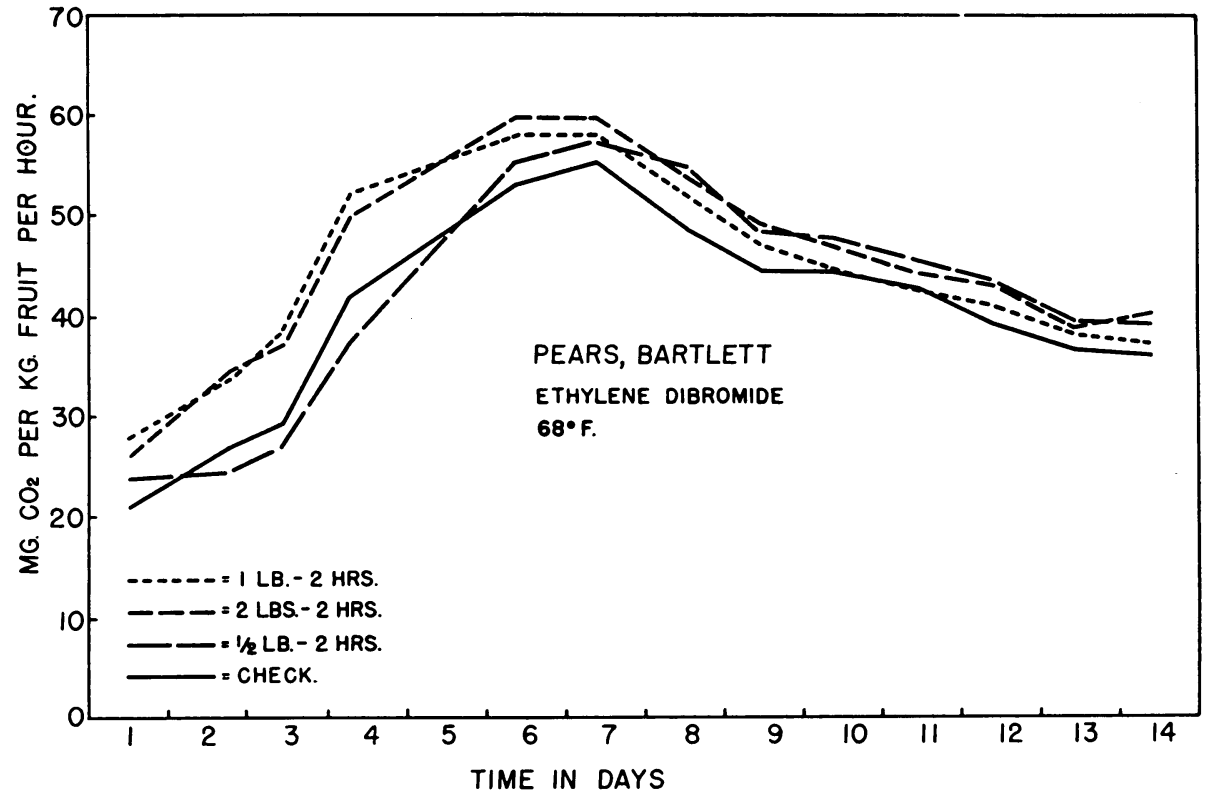

F'ig. 17. Carbon dioxide evolution from Bartlett pears fumigated with ethylene dibromide.

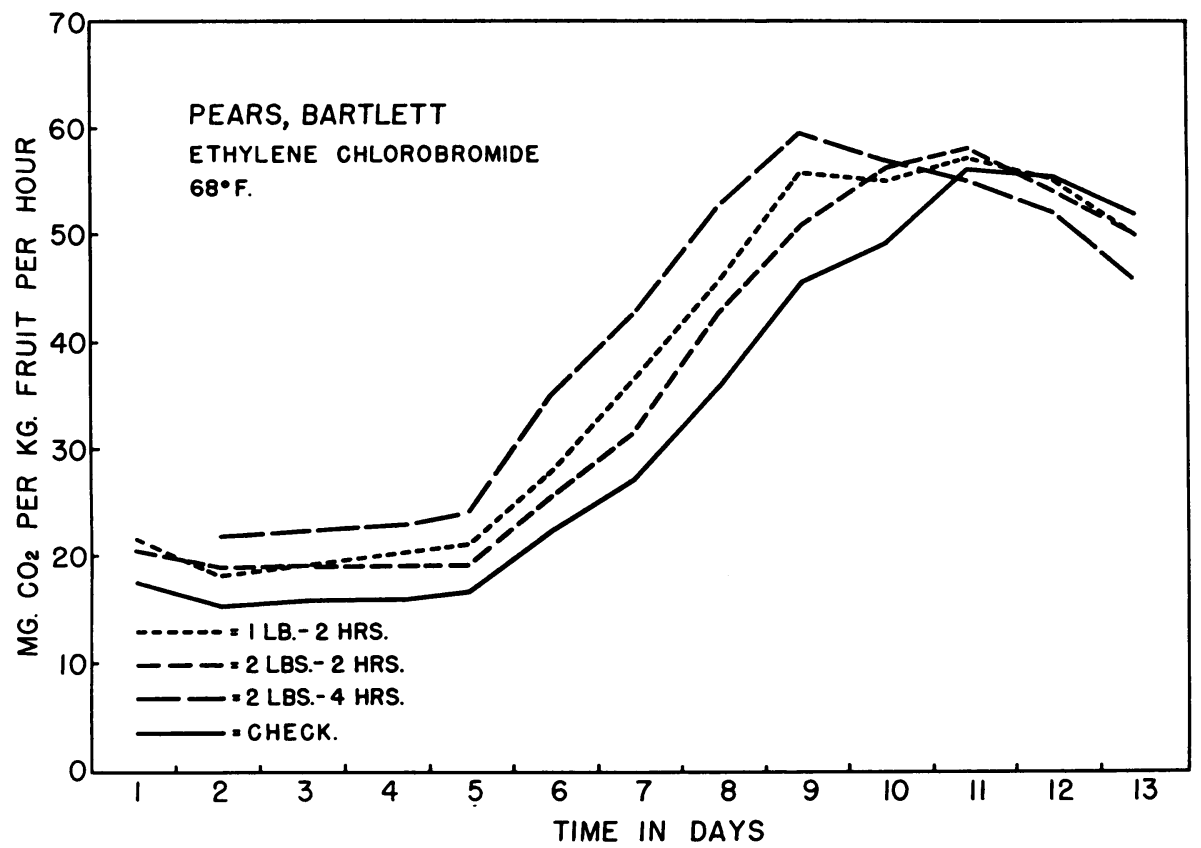

Fig. 18. Carbon dioxide evolution from Bartlett pears fumigated with ethylene chlorobromide. 


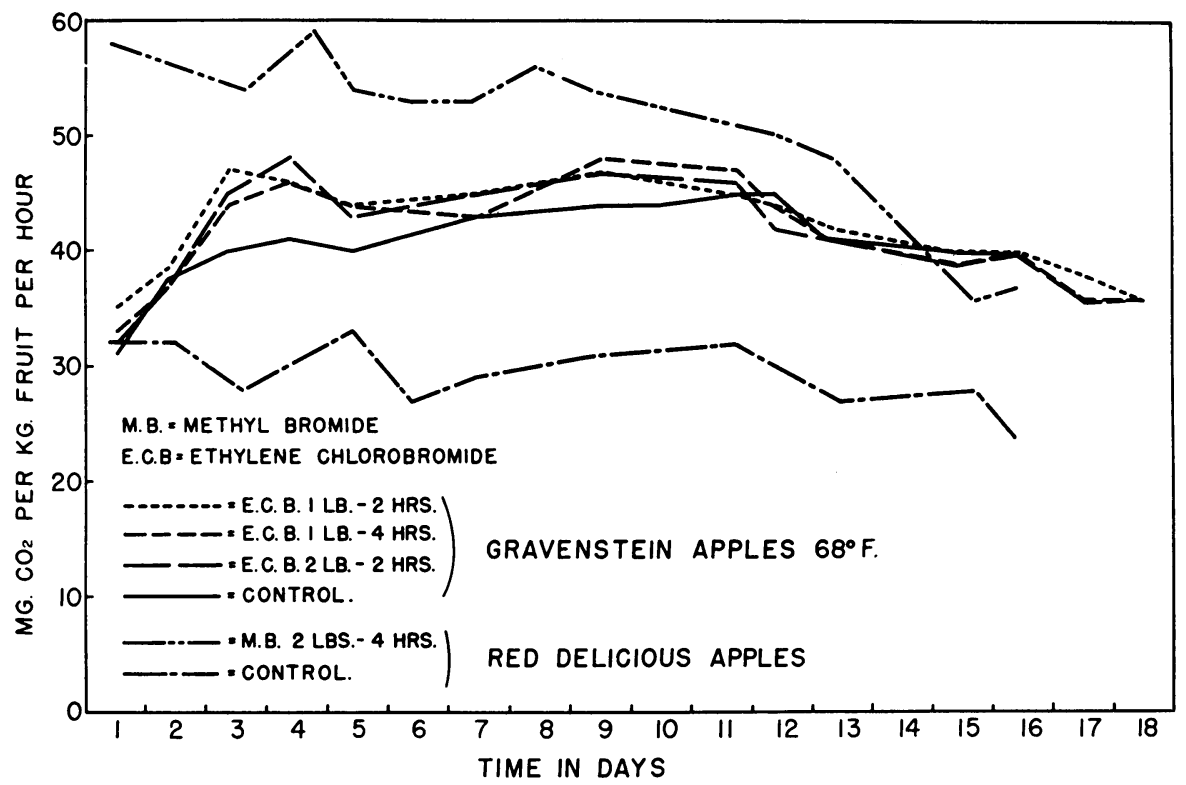

Fig. 19. Carbon dioxide evolution from apples fumigated with methyl bromide and ethylene chlorobromide.

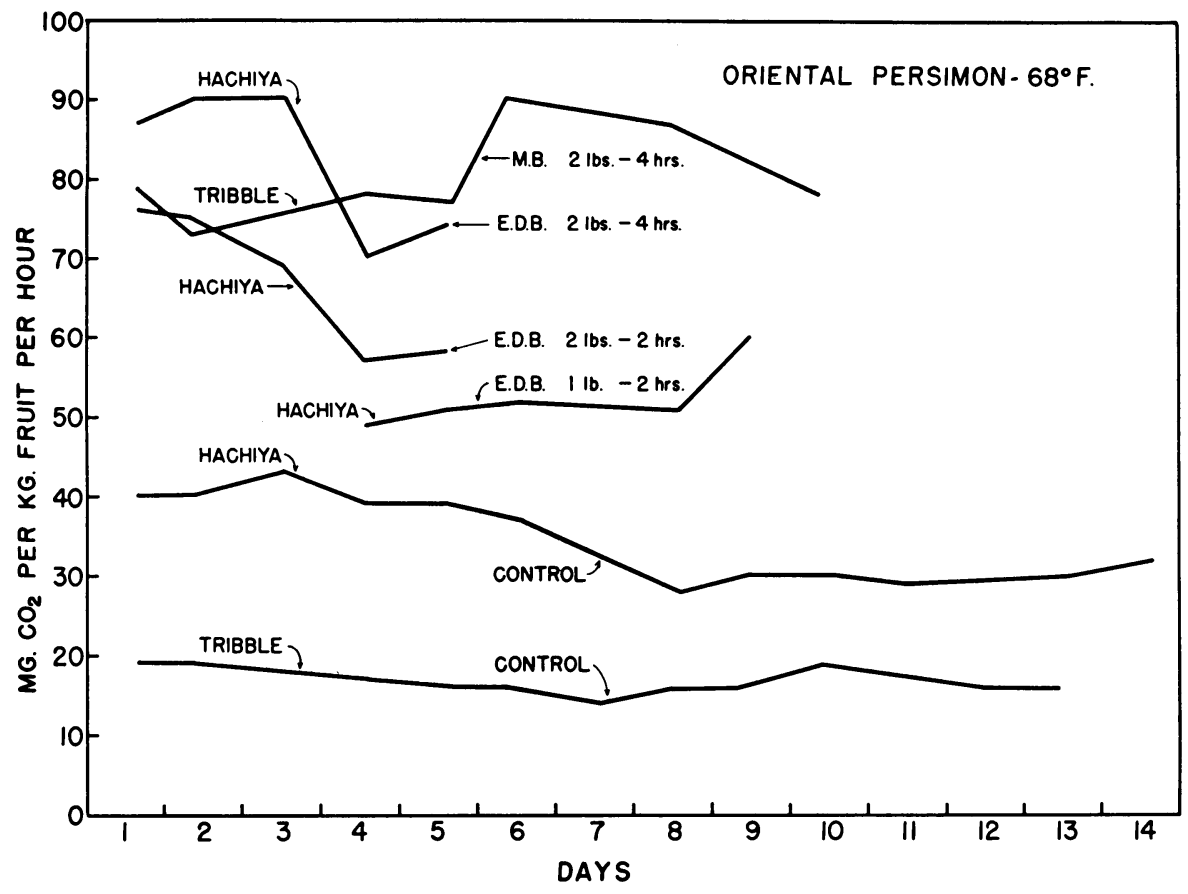

Fig. 20. Carbon dioxide evolution from persimmons fumigated with methyl bromide and ethylene dibromide. 


\section{ACKNOWLEDGMENTS}

The authors gratefully acknowledge the assistance of many individuals and coöperating agencies. Mr. J. W. Balock of the United States Department of Agriculture, Bureau of Entomology and Plant Quarantine, Honolulu, T.H., Dr. D. L. Lindgren and Mr. Harry S. Smith of the University of California, Riverside, and Mr. H. M. Armitage of the California Department of Agriculture gave valuable assistance in planning the research program and in supplying entomological information during the period of its continuance. Especial thanks are due to Mr. L. R. McKinnon for his invaluable aid in planning and assembling the "vapor heat" sterilization equipment, and to Mr. A. M. Gau, Mrs. George F. Hanna, and Mr. C. L. Hemstreet for their untiring efforts in carrying out the research program.

\section{LITERATURE CITED}

Armitage, H. M.

1951. Susceptibility of California fruits and vegetables to attack by the Oriental fruit fly (Dacus dorsalis). California Dept. Agr. Bul. 40 (1):12-20.

BALOCK, J. W.

1950. Commodity treatments. U. S. Dept. Agr., Bur. Ent. and Plant Quarantine, Honolulu, T.H. Quarterly Report, January 1 to March 31, 1950 : pp. 30, 31. (Mimeo.)

BALOCK, J. W., and D. L. LINDGREN

1951. Toxicity of various compounds as fumigants to eggs and larvae of the Oriental fruit fly. Jour. Econ. Ent. 44:657-59.

Claypool, L. L.

1940. Red color increase in fruits after harvest following treatment with methyl bromide. Amer. Soc. Hort. Sci. Proc. 38:289-90.

1941. Some effects of methyl bromide upon Bartlett pears. Blue Anchor 18 (2):16, 17, 32 .

Claypool, L. L., and R. M. Keefer

1942. A colorimetric method for $\mathrm{CO}_{2}$ determination in respiration studies. Amer. Soc. Hort. Sci. Proc. $40: 177-86$.

Halogens in Pure Colors

1950. Official methods of analysis. A.O.A.C. $689-90$.

JoNes, W. W.

1940a. Vapor heat treatment for fruits and vegetables grown in Hawaii. Hawaii Agr. Exp. Sta. Cir. 16.

1940b. Methyl bromide fumigation of papaya and tomato. Hawaii Agr. Exp. Sta. Cir. 17.

Kenworthy, A. L., and C. H. GadDis

1946. Tolerance of apple varieties to methyl bromide fumigation. Amer. Soc. Hort. Sci. Proc. 47:64-66.

KNotT, J. E., and L. L. Claypool

1940. Some responses of tomato fruits to methyl bromide fumigation. Amer. Soc. Hort. Sci. Proc. 38:501-06.

LEWIS, S. E.

1945. Methyl bromide as a fumigant: Determination in air. Soc. Chem. Ind. Jour. 64: $57-61$.

LINDGREN, D. L., and J. W. BALOCK

1950. Commodity treatments. U. S. Dept. Agr., Bur. Ent. and Plant Quarantine, Honolulu, T.H. Quarterly Report, January 1 to March 31, 1950:47-52. 
MORRIS, L. L., and L. L. ClaypoOL

1942. Some practical observations regarding methyl bromide fumigation of tomato fruits. California Dept. Agr. Bul. 31:76-79.

Phillips, G. L., and J. W. Bulger

1952. A practical method of gas analysis in ethylene dibromide fumigation. Bur. Ent. and Plant Quarantine, Hoboken, N.J. Spec. Report No. C-16. (Mimeo.)

Phillips, W. R., and H. A. U. Monro

1939. Methyl bromide injury to apples. Jour. Econ. Ent. 32:344.

RAUSCHER, W. H.

1937. Micro-, semi-micro-, and macrodeterminations of halogens in organic compounds. Indus. and Engin. Chem. Analyt. Ed. 9:296-99.

Shrader, S. A., A. W. Beshgetoor, and V. A. Stenger

1942. Determination of total and inorganic bromide in foods fumigated with methyl bromide. Indus. and Engin. Chem. Analyt. Ed. 14:1-4.

Sinclair, W. B., and P. R. Crandall

1952. Determination of ethylene dibromide in liquid and gas phases by the use of monoethanolamine. Jour. Econ. Ent. 45:80-82.

Stenger, V. A., S. A. Shrader, and A. W. Beshgetoor

1939. Analytical methods for methyl bromide. Chem. Anal. 11:121-24. 

The journal Hilgardia is published at irregular intervals, in volumes of about 600 pages. The number of issues per volume varies.

Subscriptions are not sold. The periodical is sent as published only to libraries, or to institutions in foreign countries having publications to offer in exchange.

You may obtain a single copy of any issue free, as long as the supply lasts; please request by volume and issue number from:

Agricultural Publications

Room 22, Giannini Hall

University of California

Berkeley 4, California

The limit to nonresidents of California is 10 separate issues on a single order. A list of the issues still available will be sent on request.

In our publications it is sometimes convenient to use trade names of products or equipment rather than scientific identifications. In so doing it is unavoidable in some cases that similar products which are on the market under other trade names may not be cited. No endorsement of named products is intended nor is criticism implied of similar products which are not mentioned. 


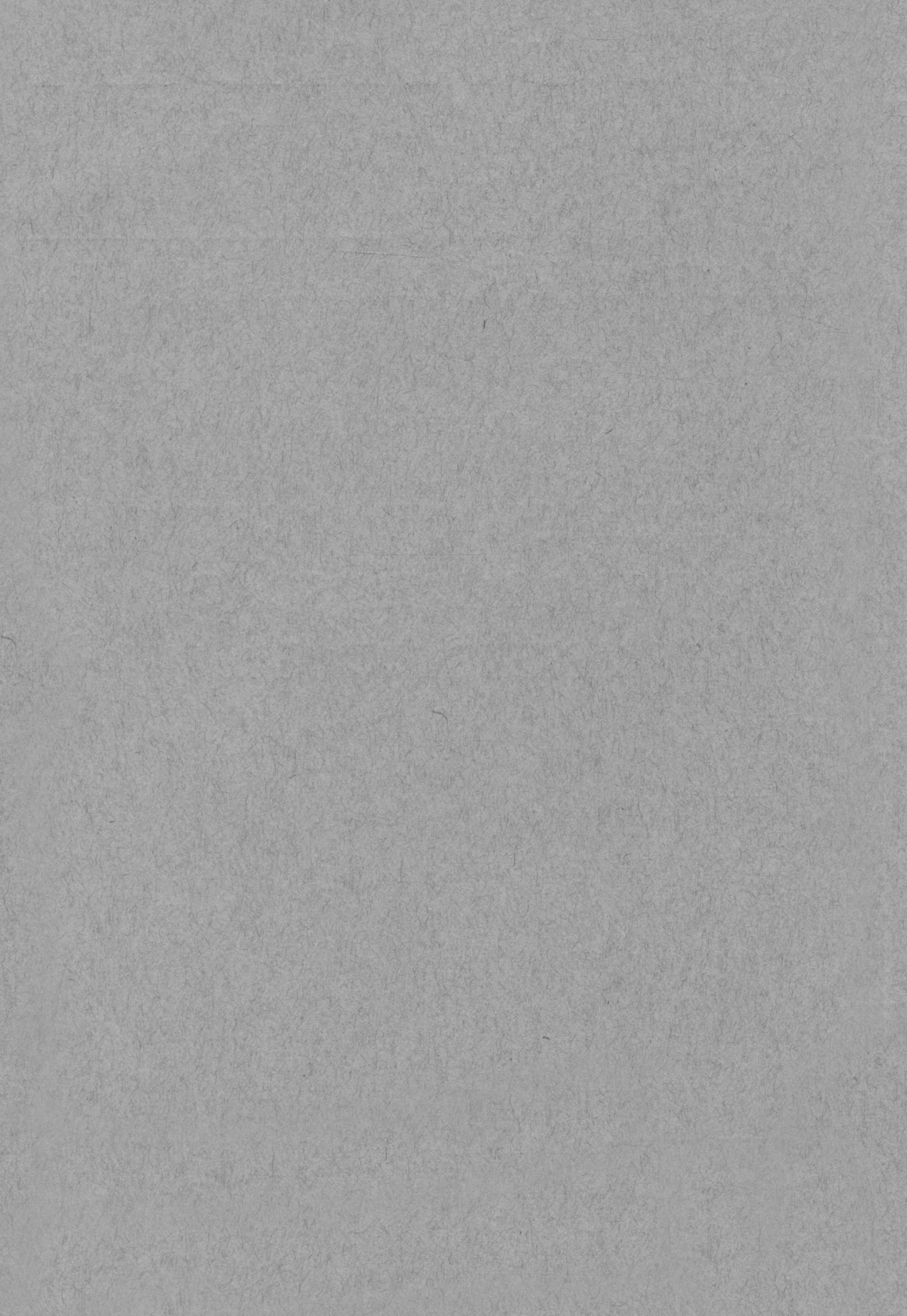

